\title{
HEADQUARTERS TIMBER SALE ENVIRONMENTAL ASSESSMENT
}

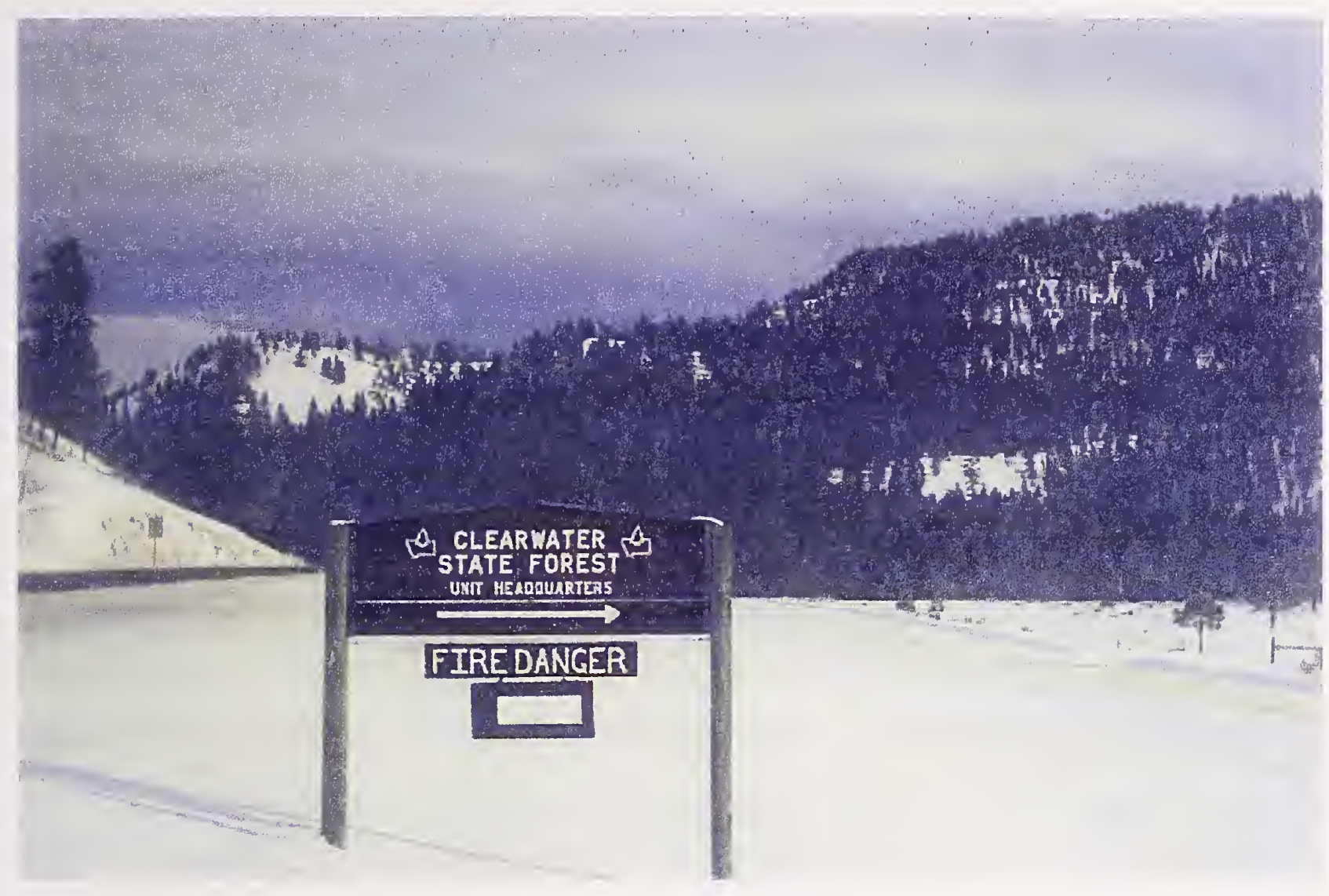

Momtana Department of Natural Resources and Conservation Southwestern Land Office

Clearwater Unir

April, 2005

STATE DOCUMENTS COLLECTION

AUG 092005

MONTANA STAIE LIBRARY

1515 E. 6th AVE.

HELENA. MONTANA 59620 
Montana State Library

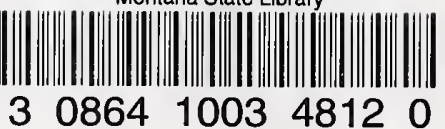




\section{Headquarters Timber Sale Environmental Assessment}

\section{Cover Sheet}

Proposed Action:

Type of document:

Lead agency:

Responsible official:

For further information:

Special Note:
The Montana Department of Natural Resources and Conservation (DNRC) proposes the salvage harvest of timber on state School Trust Lands. The sale under consideration would, at this time, harvest approximately 2 Million Board Feet (MMBF) of timber from approximately 331 acres in section 36 Township $15 \mathrm{~N}$, Range $14 \mathrm{~W}$ of Missoula County. The forest improvement practices of planting tree seedlings and pre-commercially thinning overstocked sub-merchantable trees would also occur. The proposed action would be implemented as early as June 2005 and could be completed by December 2010. These dates are approximate.

Environmental Assessment

Montana Department of Natural Resources and Conservation (DNRC).

Craig Nelson

Clearwater Unit

48455 Sperry Grade Rd.

Greenough, MT 59823-9635

(406) 244-5857

Dave Marsh

Clearwater Unit

48455 Sperry Grade Rd.

Greenough, MT 59823-9635

(406) 244-5857

Comments received in response to this Environmental Assessment will be available for public inspection and will be released in their entirety if requested pursuant to the Montana Constitution. 
Digitized by the Internet Archive in 2016 


\section{How to Read this EA (Environmental Assessment)}

To read this EA more effectively, carefully study this page. Following State regulations, we have designed and written this EA (1) to provide the Project Decision Maker with sufficient information to make an informed, reasoned decision concerning the proposed Headquarters Timber Sale and (2) to inform members of the affected and interested public of this project so that they may express their opinions to the Project Decision Maker.

This EA follows the organization and content established by the MEPA Rules (ARM 36.2.521-36.2.543). The EA consists of the following chapters.

1.0 Purpose and Need for Action

2.0 Alternatives, Including the Proposed Action

3.0 Affected Environment

4.0 Environmental Consequences

5.0 List of Preparers

6.0 References

Appendices

Chapters 1 and 2 together serve as an Executive Summary. We have written these two chapters so that non-technical readers can understand the potential environmental, technical, economic, and social consequences of taking and of not taking action.

- Chapter 1 introduces the Headquarters Timber Sale. It provides a very brief description of the proposed Headquarters Timber Sale and then explains three key things about the project: (1) the relevant environmental issues, (2) the decisions that the Project Decision Maker must make concerning this project, and (3) the relevant laws, regulations, and consultations with which the DNRC must comply.

- Chapter 2 serves as the heart of this EA. It provides detailed descriptions of Alternative A: No Entry (No Action) and Alternative B: Harvest. Most important, it includes a summary comparison of the predicted effects of these two alternatives on the human environment, providing a clear basis for choice between the two alternatives for the Project Decision Maker and the Public.

- Chapter 3 briefly describes the past and current conditions of the relevant resources (issues) in the project area that would be meaningfully affected, establishing a part of the baseline used for the comparison of the predicted effects of the alternatives.

- Chapter 4 presents the detailed, analytic predictions of the consequences of implementing Alternative A: No Harvest (No Action) and Alternative B: Harvest. These predictions include the direct, indirect, and cumulative effects of implementing the alternatives. 



\section{TABLE OF CONTENTS}

1.0 CHAPTER 1: PURPOSE OF AND NEED FOR ACTION .

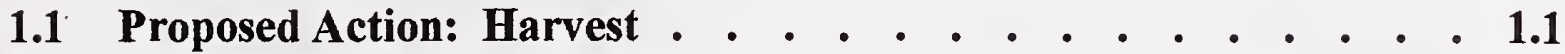

1.2 Need for the Action . . . . . . . . . . . . . . . . 1.1

1.3 Objectives of the Action . . . . . . . . . . . . . . . . 1.1

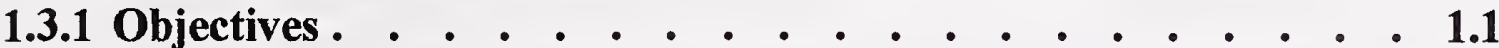

1.4 Decisions to be Made . . . . . . . . . . . . . . . . . 1.2

1.5 Relationship to the Administrative Rules for Forest Management - 1.2

1.6 Scoping Process . . . . . . . . . . . . . . . . . . . 1.2

1.6.1 Agencies, Individuals or Groups Contacted . . . . . . 1.2

1.7 Other Environmental Documents Related to This Project . • . . 1.3

1.8 Permits, Licenses and Other Authorizations Required . • • . . 1.3

1.9 Issues . . . . . . . . . . . . . . . . . . . . . . 1.3

1.9.1 Issues Studied in Detail . . . . . . . . . . . . . . 1.3

1.9.1.1 Water Quality, Soil, Fisheries, Weeds . . . . . . . . 1.3

1.9.1.1.1 Water Quality . . . . . . . . . . . . 1.3

1.9.1.1.2 Soil . . . . . . . . . . . . . . . . 1.3

1.9.1.1.3 Fisheries . . . . . . . . . . . . . 1.4

1.9.1.1.4 Weeds . . . . . . . . . . . . . . . . . 1.4

1.9.1.2 Human Environment . . . . . . . . . . . . . . 1.4

1.9.1.2.1 Recreation Opportunity, and Quality . . . . . . 1.4

1.9.1.2.2 Disruption, Noise, and Dust . . . . . . . . . . 1.4

1.9.1.2.3 Aesthetics . . . . . . . . . . . . . . . . 1.4

1.9.1.2.4 Conservation Easement . . . . . . . . . . . 1.4

1.9.1.2.5 Economics. . . . . . . . . . . . . . . . 1.4

1.9.1.2.6 Cultural and Historic Resources . . . . . . . . 1.4

1.9.1.3 Vegetation. . . . . . . . . . . . . . . . 1.4

1.9.1.3.1 Natural Role of Wildfire . . . . . . . . . . 1.4

1.9.1.3.2 Forest Fragmentation . . . . . . . . . . . 1.5

1.9.1.3.3 Leave Trees . . . . . . . . . . . . . . . 1.5

1.9.1.3.4 Natural Tree Regeneration . . . . . . . . 1.5

1.9.1.3 Wildlife. . . . . . . . . . . . . . . . 1.5

1.9.1.4.1 Endangered Species Issue . . . . . . . 1.5

1.9.1.4.2 Sensitive Species Issue. . . . . . . . . . . 1.5

1.9.1.4.3 Big.Game Issue . . . . . . . . . . . . . 1.5

1.9.2 Issues Eliminated From Further Study and Rationale for

Elimination from Further Study . . . . . . . . . . 1.5

1.9.2.1 Wildlife. . . . . . . . . . . . . . . . . 1.5

1.9.2.1.1 Canada Lynx (Federally Threatened) • . . . . 1.5

1.9.2.1.2 Perigrine Falcon. . . . . . . . . . . . . 1.6

1.9.2.1.3 Townsends Big Eared Bat . . . . . . . . . 1.6

1.9.2.1.4 Cour d'Alene Salamander . . . . . . . . . 1.6

1.9.2.1.5 Columbian Sharp-tailed Grouse . . . . . . 1.6

1.9.2.1.6 Common Loon . . . . . . . . . . . . . 1.6 
1.9.2.1.7 Northern Bog Lemming . . . . . . . . . . . 1.6

1.9.2.1.8 Mountain Plover . . . . . . . . . . . . 1.7

1.9.2.3 Vegetation. . . . . . . . . . . . . . . . . 1.7

1.9.2.2.1 Old-growth . . . . . . . . . . . . . 1.7

\subsection{CHAPTER 2: ALTERNATIVES INCLUDING THE PROPOSED}

2.1 Introduction . . . . . . . . . . . . . . . . . . . . 2.1

2.2 History and Process Used to Formulate the Alternatives . . . . . 2.1

2.3 Alternative Design, Evaluation and Selection Criteria . . . . . 2.1

2.4 Proposed Action . . . . . . . . . . . . . . . . . . 2.2

2.5 Description of Alternatives . . . . . . . . . . . . . . . 2.2

2.5.1 Alternative A: Deferred Harvest (No Action) - . . . • • . 2.2

2.5.2 Alternative B: Harvest (Action) . . . . . . . . . . . . 2.2

2.6 Description of Relevant Past, Present, and Related State Actions

Not Part of the Proposed Action . . . . . . . . . . . . . 2.4

2.7 Comparison of Activities, the Predicted Summary Achievement

of the Project Objectives, and the Predicted Environmental Effects

of All Alternatives . . . . . . . . . . . . . . . . • . 2.4

2.7.1 Summary Comparison of Project Activities . . . . . . . . 2.5

2.7.2 Summary of Predicted Achievement of Predicted Achievement of Project Objectives . . . . . . . . . . . . . . . 2.5

2.7.3 Summary Comparison of Predicted Environmental Effects. • . 2.6

Water Quality, Soil, Fisheries and Weeds . . . . . . . . . 2.6

Human Environment . . . . . . . . . . . . . . 2.6

Recreation Opportunity and Quality . . . . . . . . 2.6

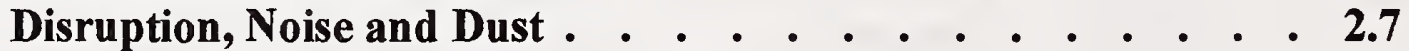

Aesthetics . . . . . . . . . . . . . . . . 2.7

Conservation Easement . . . . . . . . . . . . . . 2.7

Economics. . . . . . . . . . . . . . . . 2.7

Cultural and Historic Resources . . . . . . . . . . . 28

Vegetation. . . . . . . . . . . . . . . 2.8

Natural Role of Wildfire . . . . . . . . . . . . . . . 28

Forest Fragmentation . . . . . . . . . . . . . 28

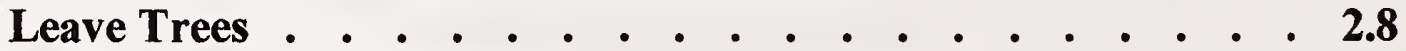

Natural Tree Regeneration . . . . . . . . . . . . . 28

Threatened and Endangered Species . . . . . . . • . . 2.8

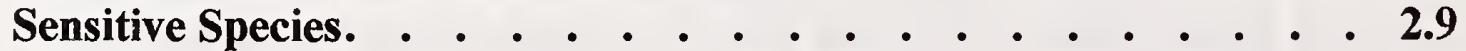

Big Game . . . . • . . . . . . . . . . . . 2.9

3.0 CHAPTER 3: AFFECTED ENVIRONMENT . . . . . . . . 3.1

3.1 Introduction . . . . . . . . . . . . . . . . . . . 3.1

3.2 Description of Relevant Affected Resources: Existing

Conditions . . . . . . . . . . . . . . 31 
3.2.1 Water Quality, Soils, Fisheries and Weeds. . . . . . . 3.1

3.2.1.1 Water Quality . . . . . . . . . . . 3.2

3.2.1.2 Soils . . . . . . . . . . . . . . . . 3.3

3.2.1.3 Cold Water Fisheries . . . . . . . . . . . 3.5

3.2.1.4 Noxious Weeds . . . . . . . . . . . . . 3.5

3.2.2 Human Environment . . . . . . . . . . . . . . 3.5

3.2.2.1 Recreation Opportunity, and Quality . . . . . 3.5

3.2.2.2 Disruption, Noise, and Dust . . . . . . . . . . 3.6

3.2.2.3 Aesthetics . . . . . . . . . . . . . . . . 3.6

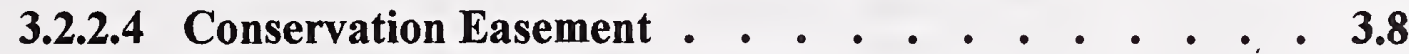

3.2.2.5 Economics . . . . . . . . . . . . . . . . . 3.9

3.2.2.6 Cultural and Historic Resources . . . . . . . . 3.10

3.2.3 Vegetation. . . . . . . . . . . . . . . . 3.10

3.2.3.1 Natural Role of Wildfire . . . . . . . . . . . . 3.10

3.2.3.1 Forest Fragmentation . . . . . . . . . . . 3.10

3.2.3.3 Leave Trees . . . . . . . . . . . . . . . . 3.11

3.2.3.4 Natural Tree Regeneration . . . . . . . . . 3.12

3.2.4 Wildlife. . . . . . . . . . . . . . . . . . . . 3.12

3.2.4.1 Threatened and Endangered Species . . . . . . 3.12

3.2.4.1.1 Bald Eagle. . . • . . . . . . . . . . . 3.12

3.2.4.1.2 Grizzly Bear . . . . . . . . . . . . . 3.13

3.2.4.1.3Gray Wolf. . . . . . . . . . . . . 3.14

3.2.4.2 Sensitive Species. . . . . . • . . . . . . 3.14

3.2.4.2.1 Pileated Woodpecker . . . . . . . . . . . . 3.14

3.2.4.2.2 Black-backed Woodpecker . . . . . . . . 3.15

3.2.4.2.3 Flammulated Owl . . . . . . . . . . . . 3.16

3.2.4.2.4Fisher . . . . . . . . . . . . . . 3.16

3.2.4.2.5 Harlequin Duck . . . . . . . . . . . . . 3.17

3.2.4.3 Big Game . . . . . . . . . . . . . . . 3.17

3.2.4.3.1 Moose . . . . . . . . . . . . . . . 3.17

3.2.4.3.2 Elk, White-tailed, and Mule Deer. . . . . . . 3.18

4.0 CHAPTER 4: ENVIRONMENTAL CONSEQUENCES - . • . . 4.1

4.1 Introduction . . . . . . . . . . . . . . . . . . . . 4.1

4.2 Predicted Attainment of the Project Objectives of the Project

Objectives of all Alternatives . . . . . . . . . . . 4.1

4.2.1 Predicted Attainment of the Project Objective . . . . . . 4.1

4.2.1.1 Alternative A: No Harvest (No Action). . . . . . . 4.1

4.2.1.2 Alternative B: Harvest (Action) . . . . . . . . . 4.1

4.3 Predicted Effects on Relevant Resources of all Alternatives. • • . 4.2

4.3.1 Water Quality, Soils, Fisheries and Weeds. . . . . . . . . 4.2

4.3.1.1 Water Quality . . . . . . . . . . . . . . . . 4.2

4.3.1.2 Soils . . . . . . . . . . . . . . . . . . . 4.3

4.3.1.3 Cold Water Fisheries . . . . . . . . . . . . . 4.5

4.3.1.4 Noxious Weeds . . . . . . . . . . . . . . . . 4.5 
4.3.2 Human Environment . . . . . . . . . . . . 4.7

4.3.2.1 Recreation Opportunity and Quality . . . . . . . . 4.7

4.3.2.2 Disruption, Noise and Dust . . . . . . . . . . . . 4.7

4.3.2.3 Aesthetics . . . . . . . . . . . . . . . . 4.8

4.3.2.4 Conservation Easement . . . . . . . . . . . . 4.11

4.3.2.5 Economics. . . . . . . . . . . . . . . . . . 4.11

4.3.2.6 Cultural and Historic Resources . . . . . . . . . 4.12

4.3.3 Vegetation . . . . . . . . . . . . . . . . . 4.13

4.3.3.1 Natural Role of Wildfire . . . . . . . . . . . 4.13

4.3.3.2 Forest Fragmentation . . . . . . . . . . . . . 4.13

4.3.3.3 Leave Trees . . . . . . . . . . . . . . . . . 4.14

4.3.3.4 Natural Tree Regeneration . . . . . . . . . . . 4.15

4.3.4 Wildlife. . . . . . . . . . . . . . . . . . . 4.15

4.3.4.1 Threatened and Endangered Species. . . . . . . 4.15

4.3.4.1.1 Bald Eagle. . . . . . . . . . . . . . . . 4.15

4.3.4.1.2 Grizzly Bear . . . . . . . . . . . . . . . 4.18

4.3.4.1.3 Gray Wolf. . . . . . . . . . . . . 4.19

4.3.4.2 Sensitive Species . . . . . . . . . . . . . 4.20

4.3.4.2.1 Pileated Woodpecker. . . . . . . . . . . 4.20

4.3.4.2.2 Black-backed Woodpecker . . . . . . . . . . 4.21

4.3.4.2.3 Flammulated Owl . . . . . . . . . . . 4.22

4.3.4.2.4 Fisher . . . . . . . . . . . . . 4.23

4.3.4.2.5 Harlequin Duck . . . . . . . . . . . . . 4.24

4.3.4.3 Big Game . . . . . . . . . . . . . . . . . 4.25

4.3.4.3.1 Moose . . . . . . . . . . . . . . 4.25

4.3.4.3.2 Elk, White-tailed and Mule Deer . . . . . . 4.26

FINDING . . . . . . . . . . . . . . . . . 3 Pages

LIST OF ABBREVIATIONS . . . . . . . . . . . . . . . . 1 Page

LIST OF INDIVIDUALS ASSOCIATED WITH THE PROJECT . . . . 5.1

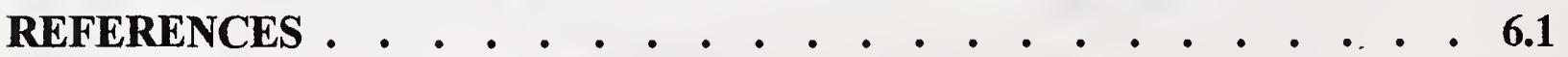

APPENDIX A: MAPS AND FIGURES

Vicinity Map . . . . . . . . . . . . . . . . . . . . . A-1

Proposed Harvest Area Map . . . . . . . . . . . . . . . . A-2

Roads Map . . . . . . . . . . . . . . . . . . . . A-3

Visual Impact Map. . . . . . . . . . . . . . . . . . A-4

Watershed Map . . . . . . . . . . . . . . . . A-5

Geology Map . . . . . . . . . . . . . . . . . . . . . A-6

Soils Map . . . . . . . . . . . . . . . . . . . . . . . A-7

Relationship of Bald Eagle Nests to Proposed Action Activities and

Surrounding Features Map. . . . . . . . . . . . . . A-8

APPENDIX B: INNITIAL AND REVISED PROPOSALS AND

PUBLIC NOTICE . . . . . . . . . . . . . . . . . 5 Pages 


\section{FINDING}

\section{HEADQUARTERS TIMBER SALE}

An Environmental Analysis (EA) has been completed for the proposed Department of Natural Resources and Conservation (DNRC) Headquarters Timber Sale. After a thorough review of the EA, project file, public correspondence, Department policies, standards and guidelines, and the Administrative Rules for Forest Management (ARM 36.11.401-450), I have made the following decisions:

\section{ALTERNATIVE SELECTED}

Two alternatives were presented and were fully analyzed in the EA: the No-Action Alternative, which includes existing activities, but does not include pre-commercial thinning, tree planting, and a timber sale $(E A, 2.5 .1)$; and the proposed action, which proposes harvesting up to 2.0 million board feet of timber from 331 acres, 50 acres would be pre-commercially thinned, and 70 acres of planting (EA 2.5.2).

For the following reasons, I have selected the proposed action without additional modifications:

a. In my opinion, the proposed action best meets the purpose and need for action and the specific project objectives listed in the EA in 1.3 Project Objectives. The proposed action generates more return to the school trust than the no action alternative ( $E A$ 4.2.1.2). The environmental effects of the proposed action are acceptable as compared with the no action alternative. No major losses in habitat, or unacceptable effects to water ( $E A$ 4.3.1.1) or soil ( $E A$ 4.3.1.2) would occur under the proposed action. No losses in habitat, or unacceptable effects to Threatened, Endangered ( $E A$ 4.3.4.I), or Sensitive ( $E_{A} A$ 4.3.4.2) species would occur under the proposed action. The action alternative would reduce the threat of catastrophic wildfire ( $E A$ 4.3.3.I), promote natural seral tree regeneration ( $E A$ 4.3.3.4), decrease the susceptibility of remaining trees to insect and disease infestations ( $E A 4$ 4.3.3.2), and provide for the opportunity to pre-commercially thin areas and plant seedlings within the analysis area (EA 4.3.2.5).

b. The analysis of identified issues did not reveal information compelling the DNRC not to implement the proposed action.

c. The proposed action includes activities to address environmental concerns expressed by DNRC staff and the public.

d. All proposed mitigations are adequate and feasible.

\section{SIGNIFICANCE OF IMPACTS}

For the following reasons, I find that the proposed action would not have significant impacts:

a. Economic Analysis

The Action Alternative would return a greater amount back to the School Trust. This increase is described in EA 4.3.2.5 Economics. Within that portion, it has been stated that although there would be forest improvement costs (pre-commercial thinning and planting) which would cost the DNRC approximately 

$\$ 26,500.00$ ("todays" dollar), it would yield up to $\$ 662,000.00$. That would yield up to $\$ 635,500.00$. This is much higher than the existing amount of money received under the Action Alternative. The existing amount of income would continue to be received during and after the timber sale.

\section{b. Forest Health}

The action alternative is designed to bring stands back to an historic condition and the age classes (EA 4.3.3.2). Immediately, these trees could serve as "feeding sites" for bark beetles in the area. These trees would be salvaged if it was economically feasible as part of this project. Generally, harvest would be expected to reduce insect and disease outbreaks in the area ( $E A$ 4.3.3.2).

\section{c. Fire Hazard}

This project is designed to emulate the effects of a low-severity, high frequency fire ( $E A$ 4.3.3.1). This will reduce fuel levels that have occurred on theis site ( $E A$ 3.2.3.I). The thinning and removal of forest fuels and canopies would decrease the general fire intensity and thereby improve the ability to control these fires. Immediately after the harvest, the fresh slash caused by that harvest would temporarily increase the fireline intensity, but that effect would decrease within a few years (EA 4.3.2.3). It can be assumed that this harvest and the decrease in long-term fire behavior would be a benefit to the surrounding landscape and to DNRC cabin leases within the project area (EA 4.3.3.2).

\section{d. Aesthetics}

Much of the project area can be seen from Highway 200 (EA 3.2.2.3). Immediately after harvest, slash would be evident after harvest ( $E A$ 4.3.2.3). The overall proposed activities should blend with the current natural mosaic and past activities on the surrounding landscape (EA 4.3.1.4).

\section{e. Noxious Weeds}

The project area has several small areas and pockets of noxious weeds (EA 3.2.1.4). Increases of ground disturbance often cause increases the areas that weeds can inhabit. This project would use Integrated Weed Management (IWM) techniques which includes: requiring cleaned equipment, treating existing weed patches with herbicide and insects, and grass seeding new roads, protection of water quality will be done by following label descriptions and not applying it near streams and areas where runoff could reach streams (EA 4.3.1.4).

\section{f. Soils}

The primary risk to soils and their productivity are compaction and erosion ( $E A$ 4.3.1.2). The project has been designed to leave tops, limbs, and unusable pieces of trees within the units to be recycled and return nutrients into the soils (EA 4.3.1.2). To restrict compaction, harvesting would only be done when the forest officer approves soil moisture, skid trail design has been approved (less than $15 \%$ of unit area), and approved conditions for ground skidding ( $E A$ 4.3.1.2).

\section{g. Hydrology and Fisheries}

The primary water body within the project area is the Blackfoot River (EA 3.2.1). The Blackfoot River is a B-1 Classified Stream in the Montana Surface Water Quality Standards. This standard is for water bodies that are considered suitable for domestic use after conventional treatment, as well as recreation, swimming, and bathing. These streams are suitable for the growth and propagation of salmonid fish and other aquatic animals ( $E A$ 3.2.1.3). No increases of sediment, settleable solids, oils, or floatable solids that would render the waters harmful, detrimental, or injurious (EA 3.2.2.l) are accepted.

Although there is a segment of road near the Blackfoot River, it goes into and outside the Limited Management Zone (LMZ) (EA 4.3.1.1) and the conservation easement (EA 3.2.2.4). All treatments near the Blackfoot River (outside the LMZ) have been stated to result in a low risk of direct, indirect, and cumulative impacts ( $E A$ 4.3.1.1) hydrologically, and for cold water fisheries (EA 4.3.1.3). 

Also during this project, the crossing of Chamberlain Creek will be changed. Currently, there is a temporary bridge (owned by the DNRC) that is placed above a rotten wooden bridge (EA 3.2.1.1). This project would replace this structure with a permanent bridge. The 124 permit required for this change has been applied for. This would increase the flow under the bridge to 100 year flood levels ( $E A$ 4.3.1.I).

\section{h. Wildlife: Threatened and Endangered Species}

Bald Eagle: There is a bald eagle nest cluster near this State section. The currently used nest is within 0.25 mile of portions of this project. A road that is proposed to be used is also adjacent and within the 0.25 mile buffer around the nest area (EA 3.2.4.1.1) (EA Attachment $A-8)$. As the primary time of harvest is during the winter, it will be easier to coordinate around the Bald Eagle breeding season and the Bald Eagle Management Plan (ARM 36.11.429).

Grizzly Bears: This project area is outside the Northern Continental Divide Ecosystem (NCDE) recovery area and has been used within the past several years (FA 3.2.4.1.2). This section is "closed" to vehicle travel by the general public (EA 3.2.4.1.2) and will reduce human and grizzly bear interactions. The timber sale has been designed to use existing topography and visual screening to block the view of grizzly bears $(E A$ 4.3.4.1.2). The harvest would not construct additional road, increase open road densities, or reduce screening along roads and riparian areas (EA 4.3.4.1.2).

\section{i. Wildlife: Sensitive Species}

Black-backed Woodpecker: The black-backed woodpecker is an irruptive species that feasts upon wood boring beetles within recently burned (1-5 years) locations $(E A$ 3.2.4.2.2). With the occurrence of the Boles Meadow, Mineral-Primm, Dirty Ike, and Stuart Peak Fires of 2003, there is over 20,000 acres of habitat within the analysis area (EA3.2.4.2.2). These factors and the silvicultural treatments proposed in this project, make the possibility of this project disturbing black-backed woodpeckers low (EA 4.3.4.2.2).

Pileated Woodpecker: The Pileated woodpecker is one of the largest woodpeckers in North America (EA 3.2.4.2.1). Pileated woodpeckers require nest snags of 29 inches DBH (but have nested in snags of 15 inches) (EA 3.2.4.2.1). Much of the harvest would reserve the trees within this size class from cutting (EA 4.3.2.2 and $E A$ 4.3.4.2.1). The proposed project would provide low effects to Pileated woodpeckers (EA 4.3.4.2.1).

Fischer: Fishers are a medium-sized animal belonging to the weasel family that prefer dense lowland spruce-fir forests with high canopy closure (EA 3.2.4.2.4). The proposed project would harvest approximately 34 acres of the 123 acres of fisher habitat (EA 4.3.4.2.4). Given management on the private and industrial lands, the minor amount of land treated on the State owned parcel, and no treatment within the riparian area, low effects are expected after this project has been implemented (EA 4.3.4.2.2).

Flammulated Owl: The flammulated owl is a tiny forest owl that inhabits warm-dry ponderosa pine and cool-dry Douglas-fir forests and is a secondary nester (FA 3.2.4.2.3). Within the project area there is an estimated 627 acres (EA 3.2.4.2.3). Where ponderosa pine is present it would be the preferred leave tree species. The planned silvicultural prescription would reduce canopy closure and reduce the density of shade tolerant species (EA 4.3.3.4). It is expected that harvest would increase the habitat for flammulated owl, and this project would have a low risk of effects ( $E A$ 4.3.4.2.3).

Harlequin Duck: Harlequin ducks require white water streams with boulder and cobble substrates. They often dive up to 3 to 5 feet under the surface to search for food, so therefore, water quality is of concern (EA 3.2.4.2.5). Since 1989, there have been 3 nests discovered on the Blackfoot River ( $E A$ 

3.2.4.2.5).. Since harvest will not occur within the SMZ and LMZ adjacent to the river it is unlikely that sediment would occur. The riparian vegetation would also not be damaged. Any operations would be outside the breeding season of the Harlequin Duck. It is expected that this project would have minor impacts ( $E A$ 4.3.4.2.5).

\section{j. Wildlife: Big Game}

Elk, White-tailed, and Mule Deer: These members of big game are quite common in the project area. The densely stocked areas provide for thermal protection and hiding cover for the deer in the winter. There are approximately 97 acres of security cover within the project area (EA 3.2.4.3.2). Given harvest plans with the project there would be a $63 \%$ reduction in snow-intercept cover and a reduction to 43 acres of security cover (EA 4.3.4.3.2). This area is across the Blackfoot River from the Clearwater Unit, and is archery only hunting ( $E A$ 3.2.4.3.2). Given these two situations, the Elk, White-tailed, and Mule Deer would see low effects (EA 4.3.4.3.2).

Moose: Use of this section is common by moose ( $E A$ 3.2.4.3.1). The retention of riparian vegetation and Archery-only hunting restrictions, provide for low risk for moose ( $E A$ 4.3.4.3.1).

\section{k. Human Environment}

This project is adjacent to the Blackfoot River (EA 3.2.l). Generally, this area receives a large amount of recreational use (EA 3.2.2.1.). The Russell Gates Memorial Campground is upstream and North of the project area. Campers as well as boaters enjoy this stretch of the River (EA 3.2.2.2 and EA 3.2.2.1). This project has given much consideration to logging season and forest improvements ( $E A$ 4.3.1.2) and Bald Eagle restrictions ( $E A$ 4.3.4.1.1). The harvest units have been designed with aesthetics as a concern ( $E A$ 4.3.2.3). The above will all help to keep effects to the human environment at a low level (EA 4.3.2).

\section{SHOULD DNRC PREPARE AN ENVIRONMENTAL IMPACT STATEMENT (EIS)?}

Based on the following, I find that an EIS does not need to be prepared:

a. The EA adequately addressed the issues identified during project development and displayed the information needed to make the decisions.

b. Evaluation of the potential impacts of the proposed timber sale indicates that no significant impacts would occur.

c. Sufficient opportunities for DNRC staff and public review and comment during project development and analysis were provided. DNRC staff and public concerns were incorporated into project design and analysis of impacts.

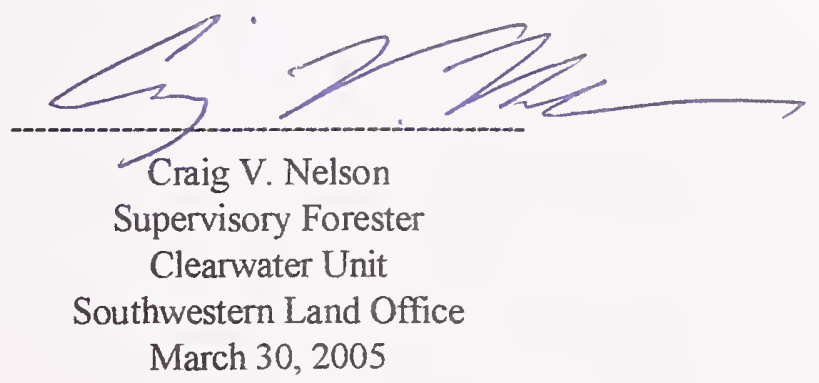





\section{ABBREVIATIONS}

\begin{tabular}{|c|c|c|c|}
\hline ARM & $\begin{array}{l}\text { Administrative Rules for } \\
\text { Montana }\end{array}$ & MCA & Montana Code Annotated \\
\hline \multirow{3}{*}{ BLM } & & MMBF & Million Board Feet \\
\hline & Bureau of Land & & \\
\hline & Management & MEPA & $\begin{array}{l}\text { Montana Environmental } \\
\text { Policy Act }\end{array}$ \\
\hline BMP & Best Management Practices & & \\
\hline \multirow{2}{*}{$\mathrm{BMU}$} & Bear Management Unit & MT & Montana \\
\hline & 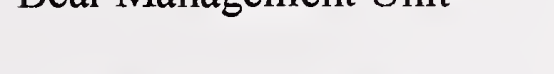 & $\mathrm{N}$ & North \\
\hline CWD & Coarse Woody Debris & & \\
\hline \multirow{2}{*}{$\mathrm{DBH}$} & Diameter at Breast Height & NW & Northwest \\
\hline & & $\mathrm{R}$ & Range \\
\hline \multirow[t]{2}{*}{ Dept } & Department & & \\
\hline & & RMZ & Riparian Management Zone \\
\hline DEQ & $\begin{array}{l}\text { Department of } \\
\text { Environmental Quality }\end{array}$ & $\mathrm{S}$ & South \\
\hline DFWP & $\begin{array}{l}\text { Department of Fish, } \\
\text { Wildlife, and Parks }\end{array}$ & SE & Southeast \\
\hline \multirow[t]{2}{*}{ DNRC } & $\begin{array}{l}\text { Department of Natural } \\
\text { Resources and }\end{array}$ & SFLMR & $\begin{array}{l}\text { State Forest Land } \\
\text { Management Rules }\end{array}$ \\
\hline & Conservation & $\mathrm{T}$ & Township \\
\hline $\mathrm{E}$ & East & TMDL & $\begin{array}{l}\text { Total Maximum Daily } \\
\text { Load }\end{array}$ \\
\hline EA & Environmental Analysis & & \\
\hline EIS & $\begin{array}{l}\text { Environmental Impact } \\
\text { Statement }\end{array}$ & USDA & $\begin{array}{l}\text { United States Department } \\
\text { of Agriculture }\end{array}$ \\
\hline FS & Forest Service & USFS & $\begin{array}{l}\text { United States Forest } \\
\text { Service }\end{array}$ \\
\hline HRA & $\begin{array}{l}\text { Hazard Reduction } \\
\text { Agreement }\end{array}$ & $\mathrm{W}$ & West \\
\hline IWM & $\begin{array}{l}\text { Integrated Weed } \\
\text { Management }\end{array}$ & & \\
\hline LMZ & Limited Management Zone & & \\
\hline MMBF & Million Board Feet & & \\
\hline
\end{tabular}



Headquarters Timber Sale - EA

CHAPTER 1 



\subsection{Chapter 1: Purpose of and Need for Action Action}

\subsection{Proposed Action: Harvest}

The Montana Department of Natural Resources and Conservation (DNRC) proposes to harvest timber and perform forest improvement projects on School Trust land in section 36, Township 15 North, Range 14 West, Missoula County. This legal description is located approximately 2.5 miles east of Clearwater Junction (Junction of Montana Highways 83 and 200) on Montana Highway 200. Appendix A, figure A-1 shows the Vicinity Area. Approximately $2 \mathrm{MMBF}$ (Million Board Feet) of timber would be harvested from roughly 331 acres within the project area. Appendix A, figure A-2 shows the approximate area proposed to be harvested. Additionally, approximately 70 acres would be planted with tree seedlings and approximately 50 acres would be precommercially thinned. The proposed action would be implemented as early as June 2005 and could be completed by December 2010 (implementation of pre-commercial thinning and tree planting would likely follow timber harvest and occur towards the end of this time period).

\subsection{Need for the Action}

The lands involved in this proposed project are held by the state of Montana in trust for the support of specific beneficiary institutions. These include public schools, state colleges and universities and other specific state institutions such as the school for the Deaf and Blind (Enabling act, February 22, 1889; 1972 Montana Constitution, Article X, Section 11). The Board of Land Commissioners and Department of Natural Resources and Conservation (DNRC) are required by law to administer these Trust Lands to produce the largest measure of reasonable and legitimate advantage over the long run for these beneficiary institutions (Section 77-1-202, MCA).

\subsection{Objectives of the Action}

In order to meet the goals of the management philosophy adopted through programmatic review in the Administrative Rules for Forest Management (ARM) (adopted March 2003), the department has set the following specific project objectives:

\subsubsection{Objectives}

1. Generate a reasonable and legitimate amount of income for the Common School grant by harvesting approximately $2 \mathrm{MMBF}$ of timber.

2. Capture the value of dying and lower vigor trees before further decline.

3. Increase future revenue generating capacity by increasing timber production and over-all stand health through tree planting and pre-commercial thinning. 


\subsection{Decisions to be Made}

- Determine if alternatives meet project objectives.

- Determine which alternatives should be selected.

- Determine if the selected alternative would cause significant environmental effects, requiring the preparation of an Environmental Impact Statement (EIS).

\subsection{Relationship to the Administrative Rules for Forest Management}

On March 13, 2003, the Department adopted Administrative Rules for Forest Management (ARM 36.11.401 through 450). The Department will manage the lands involved in this project in accordance with the Rules.

The proposed action is limited to specific management activities that are needed to implement the timber sale and forest improvement activities. This assessment documents site-specific analysis and is not a general management plan or a programmatic analysis of the area. The scope of this environmental analysis (EA) was determined through DNRC interdisciplinary analysis and public involvement.

\subsection{Scoping Process}

Public involvement in the planning of the proposed project was first solicited in 1999, (see Appendix B - Initial Proposal) again from February 12, 2001 - March 16, 2001, and finally from May 15, 2002 - June 17, 2002. Revised Proposal letters (See appendix B Revised Proposal, Feb. 12, 2001 and May 15, 2002) were mailed to known, interested parties and a public notice was published in the Missoulian (Missoula, MT) and the Seeley Swan Pathfinder (Seeley Lake, MT) newspapers during the last time period (See Appendix B-Public Notice). Multiple solicitations were the result of alterations to the original proposal, changes in DNRC personnel and priority shifts.

\subsubsection{Agencies, Individuals or Groups Contacted}

Respondents to the Scoping process twere:

$\begin{array}{ll}\text { The Ecology Center } & \text { Missoula, MT } \\ \text { Pat Brock } & \text { Ovando, MT } \\ \text { Land Lindbergh } & \text { Greenough, MT } \\ \text { Bill Potter } & \text { Greenough, MT } \\ \begin{array}{l}\text { Lewis and Clark Trail Heritage Foundation, } \\ \text { Blackfoot River Chapter }\end{array} & \text { Seeley Lake, MT } \\ \begin{array}{ll}\text { Gordon Sanders, } \\ \text { Pyramid Mtn. Lumber }\end{array} \\ \begin{array}{ll}\text { Mack Long and Mike Thompson, } \\ \text { Montana DFWP }\end{array} & \text { Seeley Lake, MT } \\ \begin{array}{ll}\text { Rebecca J. Dockter, } \\ \text { Montana DFWP }\end{array} & \text { Missoula, MT } \\ & \\ & \text { Helena, MT }\end{array}$


On November 14, 2002, an informative meeting was held for the Montana Department of Fish, Wildlife and Parks (DFWP) personnel at the proposed project area to discuss the proposal and relate it to an existing conservation easement between the two agencies.

\subsection{Other Environmental Documents Related to This Project}

The Montana Administrative Rules for Forest Management, Streamside Management Zones and Best Management Practices (2003) govern the management of forested lands owned by the Montana DNRC. The Clearwater River Timber Sale Projects EA (1999), Sour Fish EIS (1999), Lost Bear Timber Sale EA (2003) and Dirty Ike Salvage (2003) are environmental documents related to this project. The Haywire Wallace Timber Sale is another related upcoming project that is currently scoped. The Montana DFWP holds a Conservation Easement (No. D-8089). This easement includes the part of Section 36, Township 15N, Range 14W that is east of the Blackfoot River (proposed project area). Grazing lease L - 0536 is currently in effect within the project area.

\subsection{Permits, Licenses, and Other Authorizations Required}

- A 124 permit would be needed by the DNRC to upgrade a bridge crossing Chamberlain Creek through a cost sharing agreement with private landowners, Big Blackfoot Chapter of Trout Unlimited and the U S Fish and Wildlife Service.

- A road use permit with a private landowner would also be needed to use a preferred, alternate segment of road.

- DNRC is a member of the Montana Airshed Group, which regulates slash burning. DNRC would recieve an Air Quality Permit through participation in the group.

\subsection{Issues}

The following issues were identified during the scoping process. They constitute the basis for the formation of project specifications, development of mitigation measures, and assessment of environmental impacts.

\subsubsection{Issues Studied in Detail}

\subsubsection{Water Quality, Soil, Fisheries, Weeds}

\subsection{Water Quality}

There is concern that management activities associated with this project could have adverse effects on water quality.

\subsection{Soil}

There is concern that increased levels of compaction and erosion could occur as a result of proposed harvest activities. 


\subsection{Fisheries}

There is concern that the proposed timber harvest could have adverse effects on fisheries habitat.

\subsection{Weeds}

There is concern that the proposed management activities would increase the spread of noxious weeds.

\subsubsection{Human Environment}

\subsection{Recreation Opportunity, and Quality}

There is concern that public recreation quality and opportunity may become degraded as a result of the proposed action.

\subsection{Disruption, Noise, and Dust}

There is concern that project related activities may cause excessive noise, dust and disruption of privacy including landowner access to personal property.

\subsection{Aesthetics}

There is concern that aesthetic values may be reduced as a result of the proposed action.

\subsection{Conservation Easement}

There is concern that the Montana Department of Fish, Wildlife and Park's conservation easement may not be understood and adhered to.

\subsection{Economics}

There is concern that the proposed project may not meet economic objectives of state trust land management.

\subsection{Cultural and Historic Resources}

There is concern that if certain cultural or historic resources are present within the project area, they may be damaged or lost as a result of the proposed action.

\subsubsection{Vegetation}

\subsection{Natural Role of Wildfire}

There is concern that proposed harvesting may not appropriately address the forest health conditions associated with past wildfire suppression. 


\subsection{Forest Fragmentation}

There is concern that forest fragmentation may result from proposed timber harvesting.

\subsection{Leave Trees}

There is concern that appropriate tree species and wind firmness, may not be left after selective cutting.

\subsection{Natural Tree Regeneration}

There is concern that natural tree regeneration may not occur as a result of evenaged harvest treatments.

\subsubsection{Wildlife}

\subsection{Endangered species Issue}

The proposed project, if implemented, may negatively impact bald eagles, grizzly bears, gray wolves, and lynx.

\subsection{Sensitive Species Issue}

The proposed project, if implemented, may negatively impact sensitive species.

\subsection{Big Game Issue}

The proposed project, if implemented, may negatively impact mule and whitetailed deer, elk, and moose.

\subsubsection{Issues Eliminated From Further Study and Rationale for Elimination from Further Study}

\subsubsection{Wildlife}

\subsection{Canada Lynx (Federally Threatened)}

There is concern that timber harvest activities would alter lynx habitat or provide for interspecific competition. The affected parcel is comprised largely of ponderosa pine or dry Douglas-fir habitat types (Pfister et al. 1977), which are generally considered not to be preferred lynx habitat types (Ruediger et al. 2000). In conjunction with the lack of preferred habitat types, the project area is adjacent to a significant winter range for elk and mule deer (i.e., the BlackfootClearwater Wildlife Management Area), thus, the project area would likely not receive much use by lynx due to these factors. Thus, the proposed action would have low risk of direct, indirect, or cumulative effects to lynx. 


\subsection{Peregrine Falcon}

There is concern that timber harvest activities would disturb nesting peregrine falcons. The nearest known peregrine falcon nest is located approximately 25 miles NW of the affected area. Thus, the proposed action would have low risk of direct, indirect, or cumulative effects to this species.

\subsection{Townsend's Big-eared Bat}

There is concern that timber harvest activities would disturb Townsend's bigeared bats. This species requires caves, caverns, or old mines for hibernacula. The nearest mine is located approximately 8 miles SW of the project area in section $5, \mathrm{~T} 13 \mathrm{~N}, \mathrm{R} 14 \mathrm{~W}$. Current conservation strategies for this species indicate that a $500-\mathrm{ft}$ radius buffer be installed around mine entrances to partially mitigate for the effects of timber harvest (Pierson et al. 1999). Thus, with the proposed action located 8 miles distant from the mine entrance, there would be low risk of direct, indirect, or cumulative effects to this species.

\subsection{Coeur d'Alene Salamander}

There is concern that timber harvest activities could affect this species. This species requires waterfall spray zones, talus, or cascading streams. There are no known areas of talus, waterfalls, or splash zones within the affected area. Thus, the proposed action would have low risk of direct, indirect, or cumulative effects to this species.

\subsection{Columbian Sharp-tailed Grouse}

There is concern that timber harvest activities could affect this species. The nearest known population of Columbian Sharp-tailed grouse occurs near Ovando, MT. Thus, the proposed action would have low risk of direct, indirect, or cumulative effects to this species.

\subsection{Common Loon}

The common loon is a fish-eating bird that breeds and nests on lakes and ponds. A breeding pair and 1 juvenile were sighted in the Cottonwood Creek area (section 17, T15N, R13W; 2.5 miles NE of the project area) in 1996 (Montana Natural Heritage Database). However, this area would be upstream of the proposed project area. Thus, low risk of direct, indirect, or cumulative effects would be expected to common loons.

\subsection{Northern Bog Lemming}

There is concern that timber harvest activities could affect this species. The sphagnum meadows, bogs or fens with thick moss mats required by this species are not present within the harvest area. Thus, the proposed action would have low risk of direct, indirect, or cumulative effects to this species. 


\subsection{Mountain Plover}

There is concern that timber harvest activities could affect this species. The short-grass prairie habitats required by this species are not present within the harvest area. Thus, the proposed action would have low risk of direct, indirect, or cumulative effects to this species.

\subsubsection{Vegetation}

\subsection{Old-growth}

There is concern that timber harvest activities may adversely impact old-growth stands. The project area was inventoried for the presence of old-growth as defined under ARM 36.11.403, (48) and 36.11.418. These definitions refer to stands, which meet or exceed the minimum number, size and age of large trees. This inventory took place during December, 2001. No stands meeting this definition were found to be present. This finding concludes that the proposed action would have low risk of direct, indirect, or cumulative effects to oldgrowth. 

Headquarters Timber Sale - EA

CHAPTER 2 



\subsection{Chapter 2: Alternatives Including the Proposed Action}

\subsection{Introduction}

The purpose of Chapter 2 is to describe each alternative and compare them by summarizing their environmental consequences. Alternatives were developed through scoping and development of issues, input from Interdisciplinary Team (IDT) specialists, and guidance from Montana Administrative Rules for Forest Management. In addition, compliance with trust mandates helped to shape alternatives. This chapter contains summaries and comparisons of the action and effects involved with each alternative. The environmental consequences of each alternative are listed here for comparative purpose. However, more detailed information can be found in chapters 3 and 4 . This is done to provide a clear basis for choice among the options for the decision maker and the public.

This chapter has six sections:

- History and Process Used to Formulate the Alternatives

- Alternative Design, Evaluation, and Selection Criteria

- Proposed Action

- Description of Proposed Alternatives

- Description of Relevant Past, Present, and Reasonably Foreseeable Future DNRC Actions Not Part of the Proposed Action

- Summary Comparison of the Activities, the Predicted Achievement of the Project Objectives and the Predicted Environmental Effects of All Alternatives

\subsection{History and Process Used to Formulate the Alternatives}

Internal review and public scoping of the initial proposal were used to develop alternatives. Responses from external parties were reviewed. The major environmental issues identified during the scoping process were defined and summarized in chapter 1 . In order to understand how the proposed harvest would effect the environment, its effects were contrasted to those of Alternative A: (No Action). Using the guidance of the MEPA Rules, the responses received, and the issues developed during the internal scoping, the team designed Alternative B: Harvest, to satisfy the needs and meet the objectives of the project.

\subsection{Alternative Design, Evaluation and Selection Criteria}

In selecting an alternative, the Project Decision Maker will consider how each alternative would meet project objectives, and how each alternative would affect relevant environmental issues. 


\subsection{Proposed Action}

This project has been developed as a single proposed action, in which any potentially significant issues with members of the public, private organizations, and other units of government have been proactively managed, negotiated and resolved to the extent possible during project development. Within the single proposed action, alternative designs, mitigations, and controls have been considered through a dynamic process involving public participation, interdisciplinary methods and inter-entity consultations. Understandings, conclusions, and agreements arrived at through such collaborative work are integrated and adopted into the final design, mitigations and controls of the proposed action.

\subsection{Description of Alternatives}

\subsubsection{Alternative A: Deferred Harvest (No Action)}

Timber harvest would be deferred until a later period. However, ongoing DNRC permitted and approved activities including wildfire suppression would continue. The Montana Department of Fish, Wildlife and Parks would continue to have the conservation easement. Forest succession would be expected to continue.

\subsubsection{Alternative B: Harvest (Action)}

- The proposed harvest would yield approximately $2 \mathrm{MMBF}$ of saw timber, from approximately 331 acres (see Appendix A, figure A-2).

- Approximately 8.2 miles of existing road would be maintained or re-conditioned to meet BMP standards.

- Approximately 331 acres would be harvested with a ground based logging system.

- Logging slash would be treated in accordance with the Montana Hazard Reduction Agreement Law (1947). Downed woody debris retention requirements would also be implemented.

- This alternative would provide between $\$ 544,000.00$ - $\$ 662,000.00 \quad(4.3 .2 .5)$ in revenue to the common school trust.

- A bridge crossing Chamberlain Creek on private land would be upgraded. This bridge is part of a DNRC easement providing access to the project area.

- Strategies would be used to control noxious weed infestations including the use of herbicides. 
- Approximately 70 acres would be planted with tree seedlings of representative species. Herbicides such as Pronone or Hexazinone may be applied in conjunction with planting to control grass competition and help insure seedling survival.

- Approximately 50 acres would be pre-commercially thinned. These areas are overstocked with sub-merchantable sized trees, and the treatment would increase tree vigor.

\section{Harvest Treatment Description}

In general, harvest treatments are intended to produce revenue for the school trust, while improving growing conditions for residual trees. In suitable areas, overstory tree canopy would be reduced. The new spacing should improve conditions for the establishment of natural Ponderosa pine regeneration.

Across most of the treated area, selection harvest would be expected to emulate presettlement conditions. Fires of that period were frequent and displayed a low to moderate severity. Most sound snags would be retained however; most recently dead trees containing usable sawlog material would be harvested. Live leave trees would be selected based on their species, visible health, and vigor characteristics. This would be done in a manner somewhat representative of the following wildfire description:

Scientific evidence suggests that low to moderate fires historically converted dense stands of pole sized and larger trees to a more open condition, and subsequent light burning maintained stands in a parklike state. Frequent low or moderate fires favored larch and ponderosa pine over Douglas-fir in stands where these species occurred (Fischer and Bradley 1987).

Harvest units would be treated as follows (for visual reference, see Appendix A, figure A2):

Table 2-1: Approximate Harvest Statistics Goals for Removal (Saw-timber Sized Trees)

\begin{tabular}{|c|c|c|c|c|c|}
\hline $\begin{array}{c}\text { Harvest } \\
\text { Unit }\end{array}$ & Acres & $\begin{array}{c}\text { Prominent Size } \\
\text { Class Removed }\end{array}$ & $\begin{array}{c}\text { Trees per Acre } \\
\text { Removed }\end{array}$ & $\begin{array}{c}\text { Prominent Species } \\
\text { Removed }\end{array}$ & $\begin{array}{c}\text { Basal Area Per } \\
\text { Acre Removed }\end{array}$ \\
\hline $36-1$ & 45 & $\begin{array}{c}\text { Small to } \\
\text { Intermediate }\end{array}$ & 50 & Douglas-fir & 50 \\
\hline $36-2$ & 12 & $\begin{array}{c}\text { Small to } \\
\text { Intermediate }\end{array}$ & 60 & Douglas-fir & 60 \\
\hline $36-3$ & 127 & $\begin{array}{c}\text { Small to } \\
\text { Intermediate }\end{array}$ & 60 & Douglas-fir & 50 \\
\hline $36-4$ & 123 & Variable & 40 & Ponderosa pine & 50 \\
\hline $36-a$ & 13 & $\begin{array}{c}\text { Small to } \\
\text { Intermediate }\end{array}$ & 20 & Douglas-fir & 15 \\
\hline $36-a 1$ & 8 & Variable & $5-10$ & Douglas-fir & 20 \\
\hline $36-a 2$ & 3 & Variable & $1-10$ & Ponderosa pine & 20 \\
\hline
\end{tabular}


Table 2-2: Approximate Harvest Statistics Goals for Residual Stands (Saw-timber Sized Trees)

\begin{tabular}{|c|c|c|c|}
\hline Harvest Unit & Acres & Residual Trees Per Acre & $\begin{array}{c}\text { Residual Basal Area } \\
\text { Per Acre }\end{array}$ \\
\hline $36-1$ & 45 & 20 & 30 \\
\hline $36-2$ & 12 & 20 & 40 \\
\hline $36-3$ & 127 & 15 & 30 \\
\hline $36-4$ & 123 & 20 & 40 \\
\hline $36-\mathrm{a}$ & 13 & $15-30$ & $30-40$ \\
\hline $36-\mathrm{a} 1$ & 8 & $5-20$ & $10-20$ \\
\hline $36-\mathrm{a} 2$ & 3 & $5-20$ & $10-20$ \\
\hline
\end{tabular}

\subsection{Description of Relevant Past, Present, and Related Future State Actions Not Part of the Proposed Action}

- Livestock grazing lease \# 0536 has been in effect and would remain.

- Conservation Easement No. D-8089 with the Montana DFWP has been in effect since 1983 and would remain.

- Timber harvest has occurred in the project area during 1954-1957, 1967, and 1969-1972.

- Wildfire suppression activities have occurred and would continue.

- Biological weed control has been conducted in attempt to control leafy spurge through release of Apthonia lacertosa. Potential exists for future biological control measures, should opportunities arise.

2.7 Comparison of Activities, the Predicted Summary Achievement of the Project Objectives, and the Predicted Environmental Effects of All Alternatives

\subsubsection{Summary Comparison of Project Activities}

Table 2-3: $\quad$ SUMMARY COMPARISON OF PROJECT ACTIVITIES OF ALTERNATIVES A AND B.

The following table provides a comparison of the on-the ground activities that would occur if either $A$ or $B$ were implemented.

\begin{tabular}{|l|c|c|}
\hline Activity & Alt. A & Alt. B \\
\hline Timber Sale analysis area (acres) & 0 & 640 \\
\hline Proposed tractor harvest area (acres) & 0 & 331 \\
\hline Road re-condition / maintenance (miles) permanent & 0 & 8.2 \\
\hline Tree seedling planting (approximate acres) & 0 & 70 \\
\hline Pre-commercial tree thinning (approximate acres) & 0 & 50 \\
\hline
\end{tabular}


All roads are closed to public motorized use through adjacent private property and would remain in that condition after completion of alternative $\mathrm{B}$.

\subsubsection{Summary of Predicted Achievement of Project Objectives}

\section{Table 2-4: SUMMARY COMPARISON OF PREDICTED ACHIEVEMENT OF PROJECT OBJECTIVE}

\begin{tabular}{|l|l|c|c|}
\hline Objective & Indicators & Alt. A & Alt B \\
\hline $\begin{array}{l}\text { Harvest approximately 2 Million board feet } \\
\text { of timber to generate revenue for the } \\
\text { Common School (CS) grant. }\end{array}$ & $\begin{array}{l}\text { Stumpage } \\
\text { receipts in } \\
\text { dollars }\end{array}$ & 0 & $\begin{array}{l}\$ 544,000.00 \\
\text { to } \\
\$ 662,000.00\end{array}$ \\
\hline $\begin{array}{l}\text { Capture the value of dying and lower vigor } \\
\text { trees before further decline. }\end{array}$ & $\begin{array}{l}\text { Value } \\
\text { captured? }\end{array}$ & None & Some \\
\hline $\begin{array}{l}\text { Increase future revenue generating capacity } \\
\text { by increasing timber production and overall } \\
\text { stand health through tree planting and pre- } \\
\text { commercial thinning. }\end{array}$ & $\begin{array}{l}\text { Approximate } \\
\text { acres treated }\end{array}$ & 0 & 120 \\
\hline
\end{tabular}




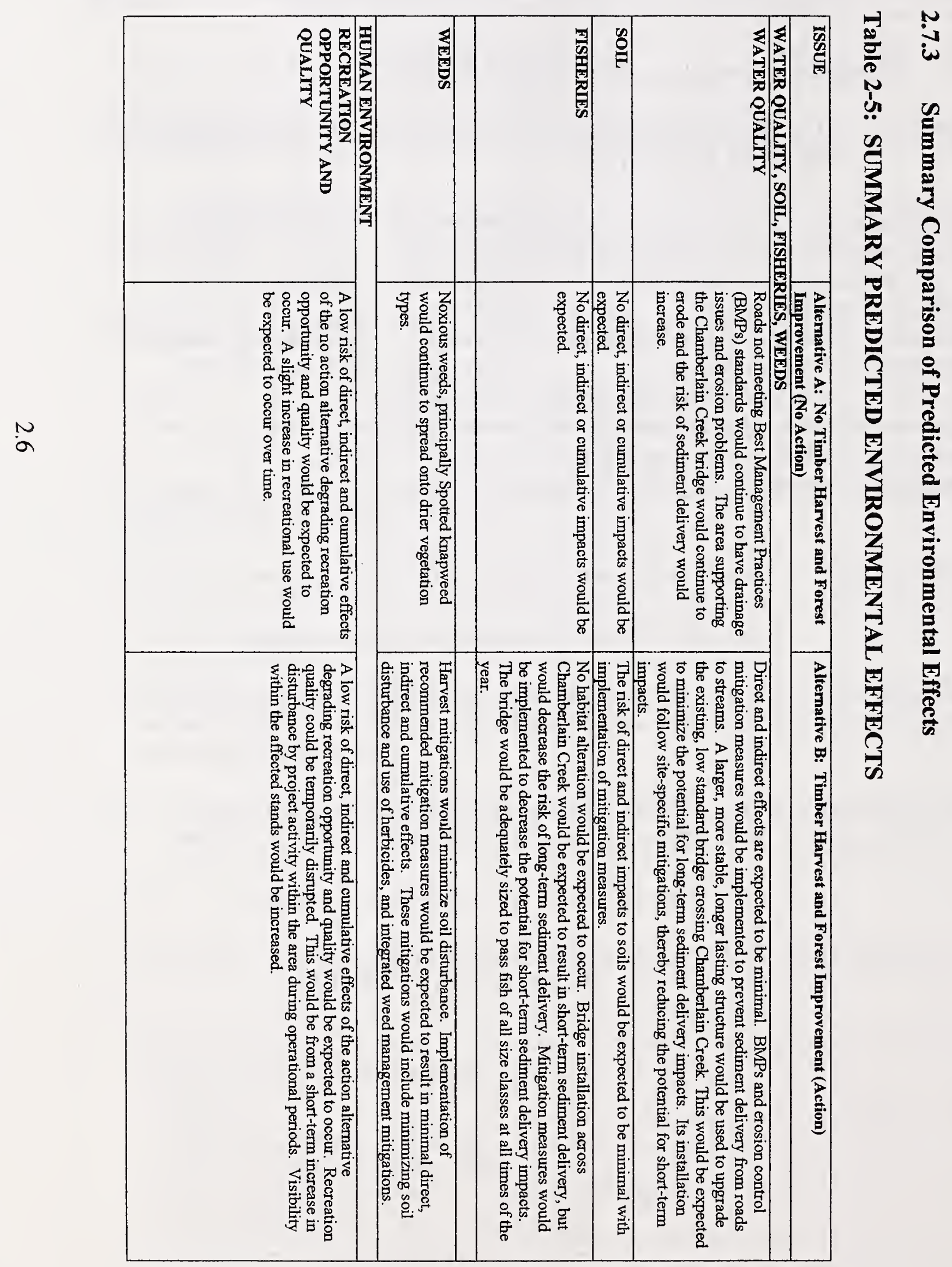

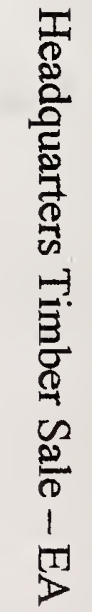




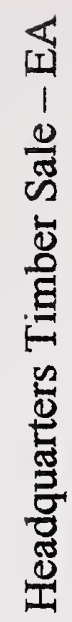

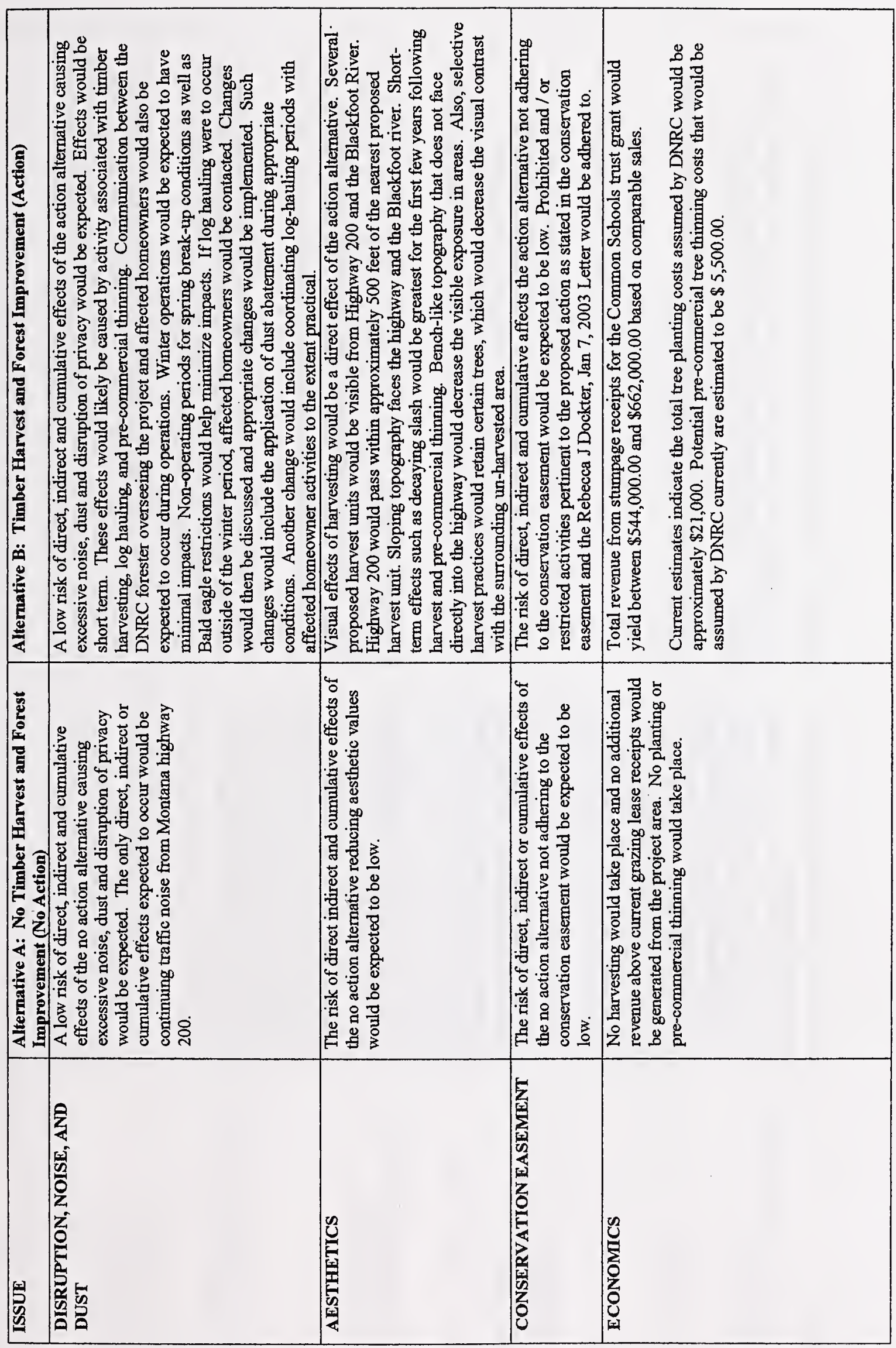




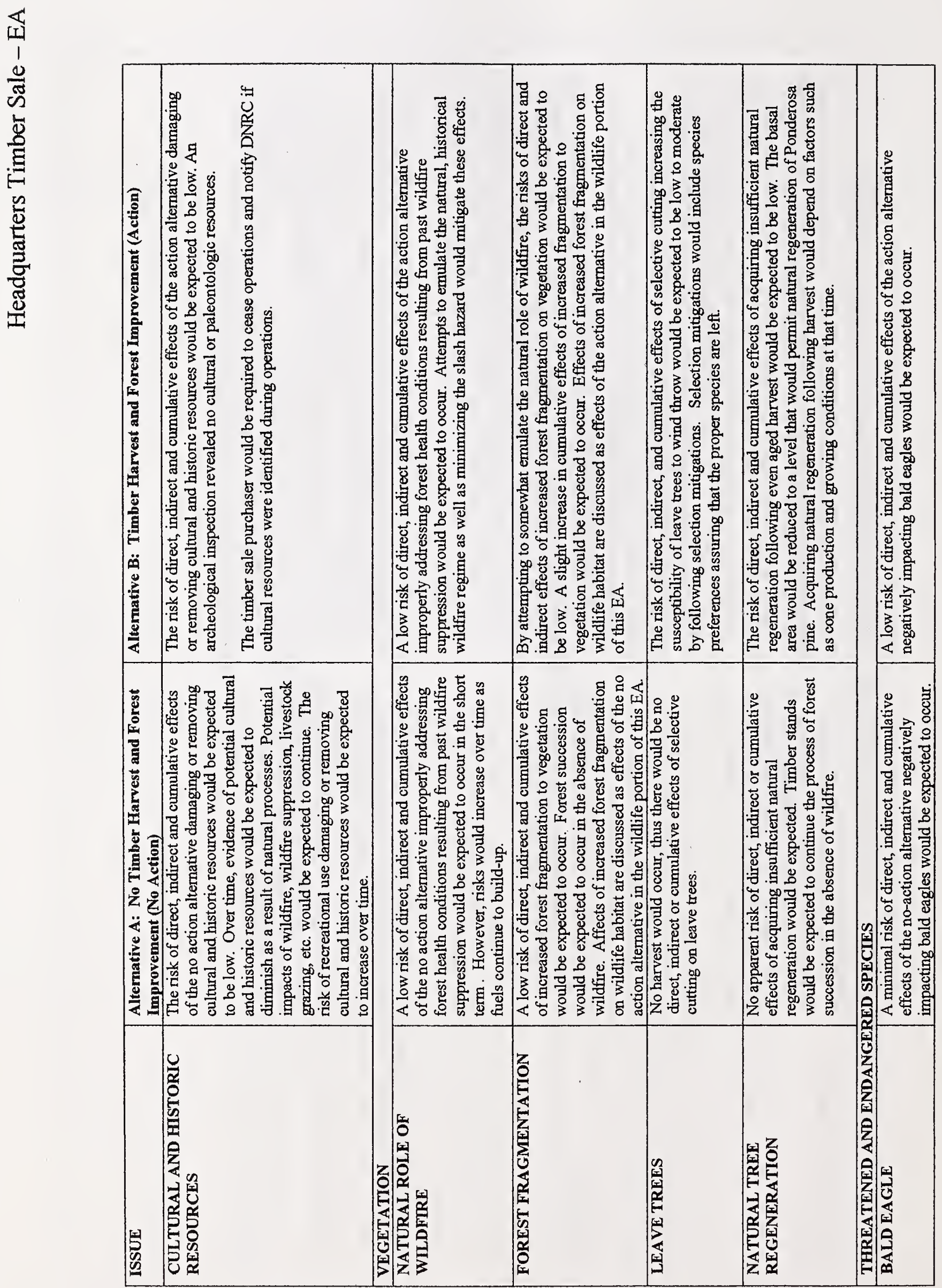




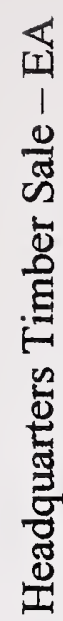

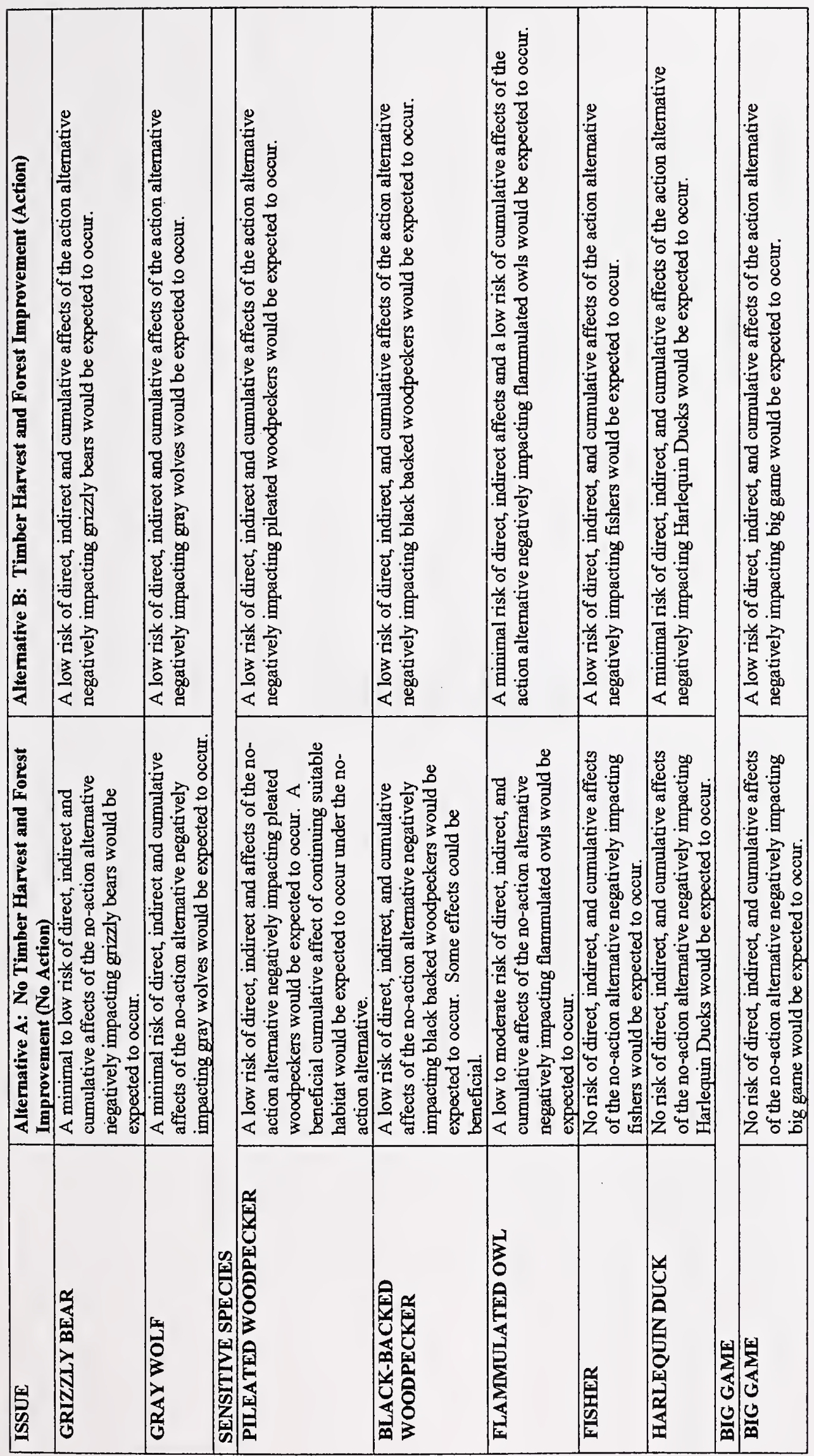




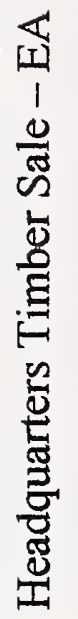

\begin{tabular}{|c|c|c|c|c|c|c|}
\hline 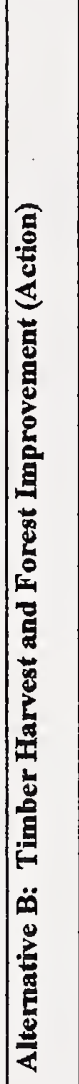 & 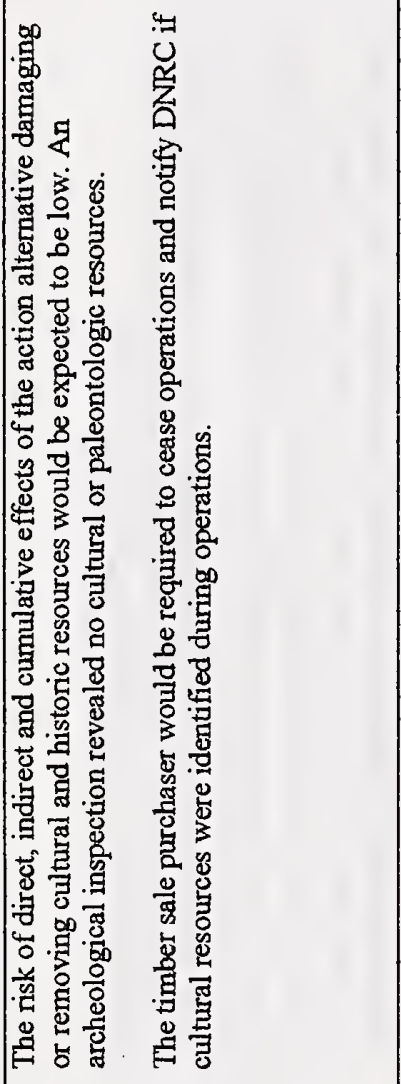 & 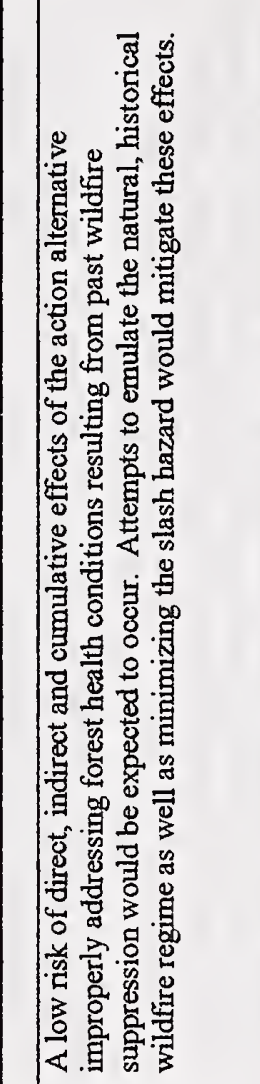 & 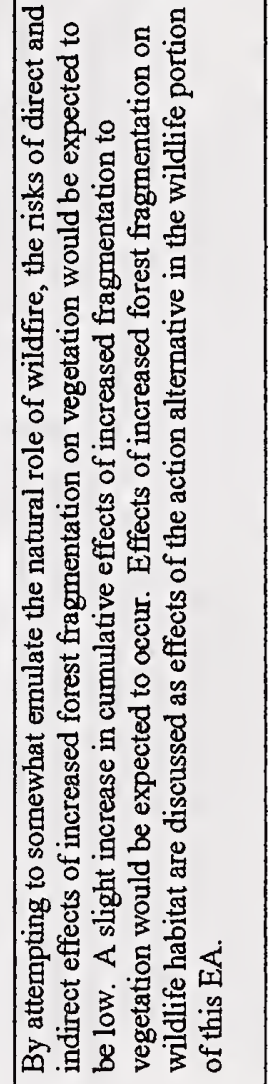 & 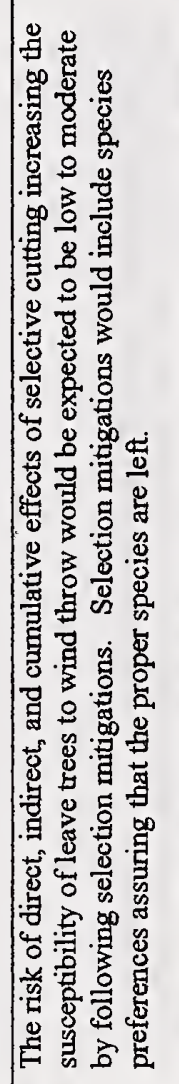 & 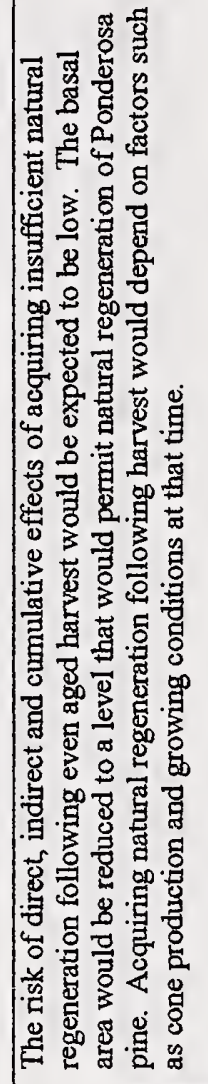 & 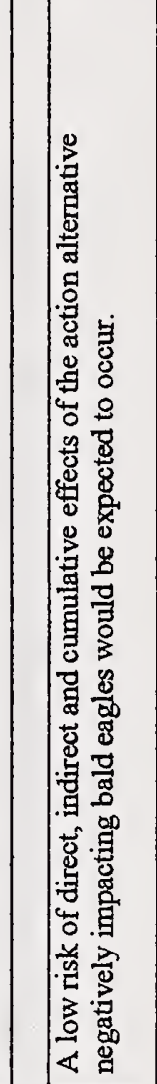 \\
\hline 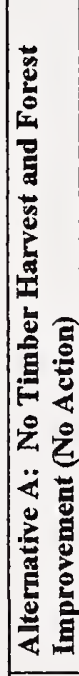 & 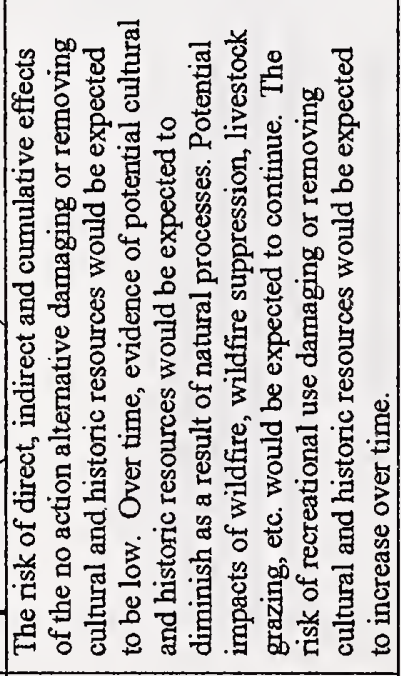 & 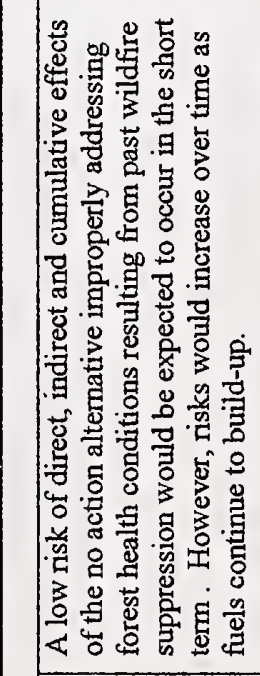 & 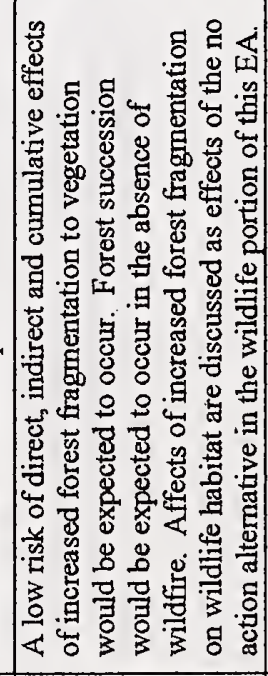 & 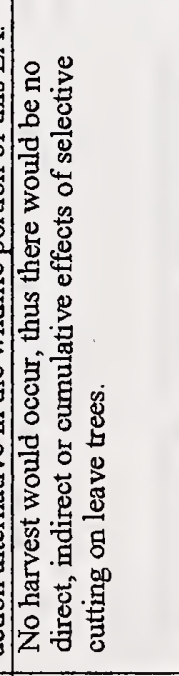 & 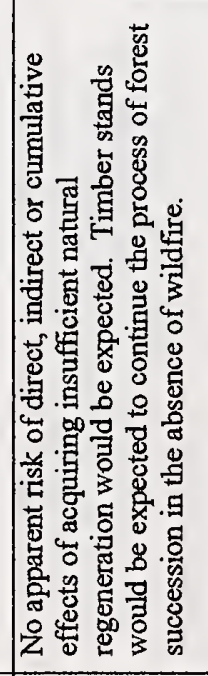 & 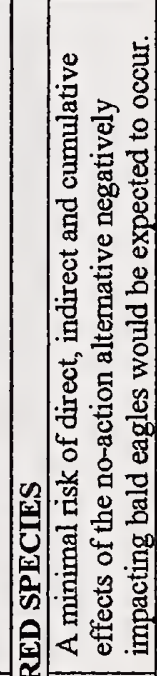 \\
\hline 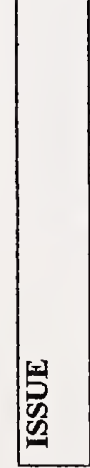 & 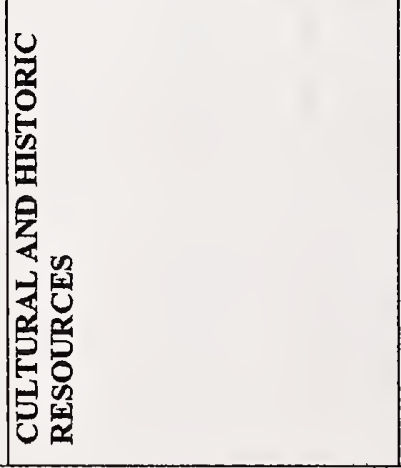 & 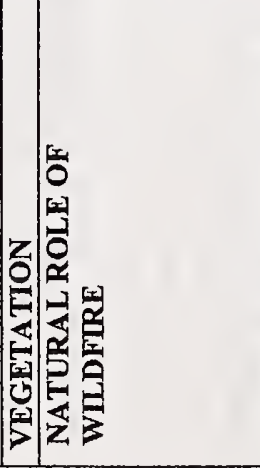 & 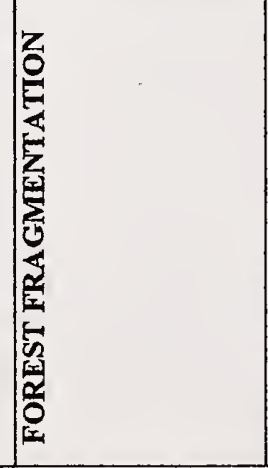 & 资 & 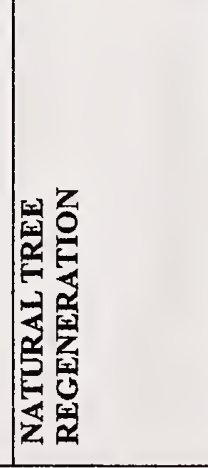 & 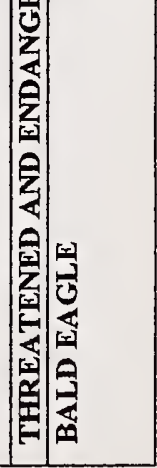 \\
\hline
\end{tabular}

$\stackrel{\infty}{\sim}$ 


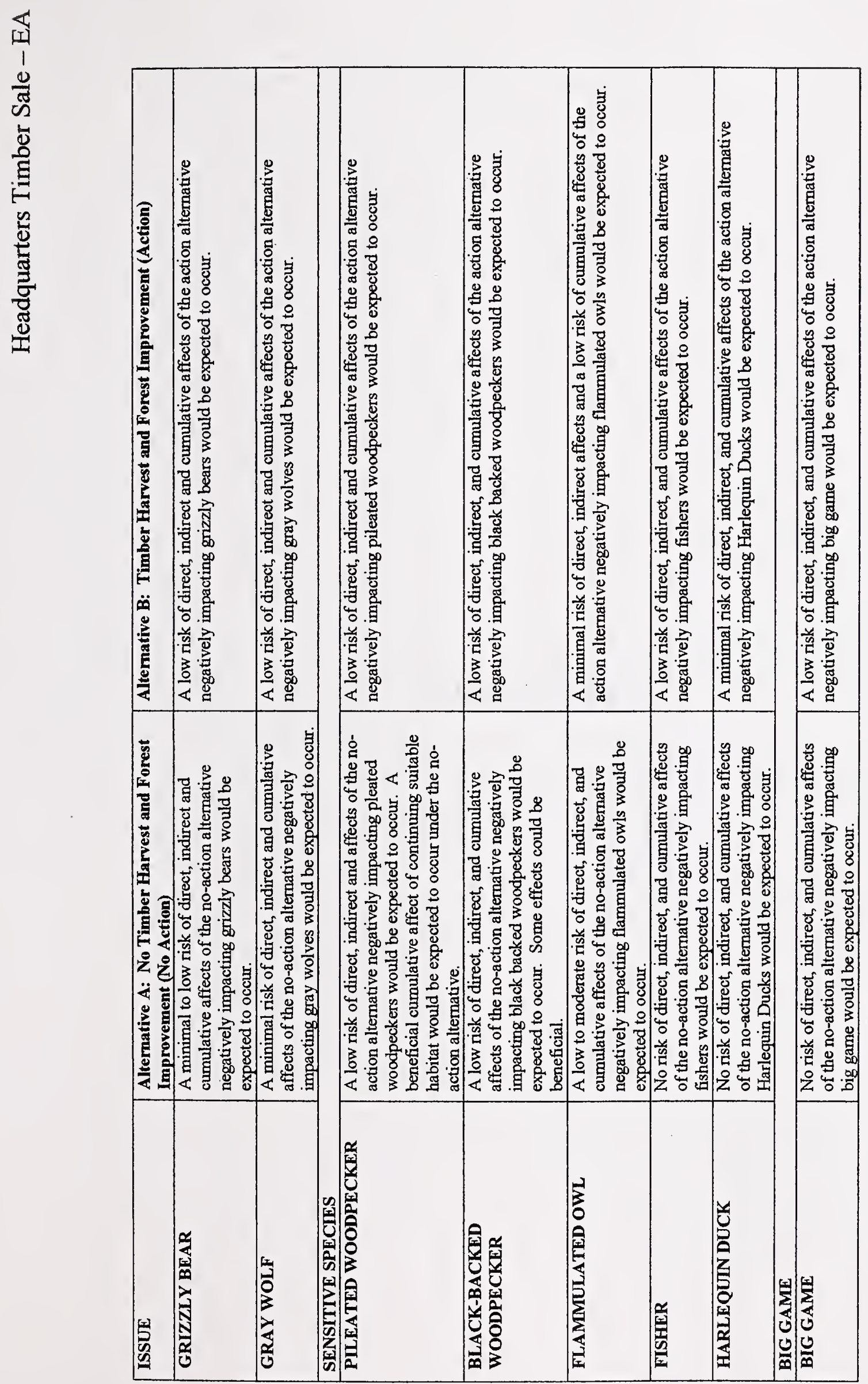



Headquarters Timber Sale - EA

CHAPTER 3 



\subsection{Chapter 3: Affected Environment}

\subsection{Introduction}

Chapter 3 describes the affected environment in terms of issues and concerns, and is organized by resource and affected issues. This description of the affected environment can be used as a baseline to compare the effects of alternatives described in Chapter 4.

\subsection{Description of Relevant Affected Resources: Existing Conditions}

\subsubsection{Water Quality, Soils, Fisheries and Weeds}

\section{Analysis Methods}

A watershed analysis was completed by a DNRC hydrologist for the proposed sale area to determine the existing direct, indirect and cumulative effects to water quality, soils, fisheries and noxious weeds.

These areas were evaluated using a course filter approach. A fine filter approach, including a water yield analysis was not conducted for this timber sale, due to the anticipated low potential for cumulative impacts.

Reconnaissance level surveys were used to observe existing conditions of soils, noxious weeds and water quality. Existing conditions of fisheries habitat was obtained through data collected by the Montana Department of Fish Wildlife and Parks and observing stream channel habitat conditions.

All existing roads in the proposed project area were evaluated by a DNRC hydrologist for past and potential impacts.

\section{Analysis Area}

Refer to Watershed Map (Appendix A, Figure A-5) for Specific Locations.

The proposed project area is located on moderate to steep slopes, ranging from 0 $80 \%$. The only class I stream channel located in the project area is the Blackfoot River in Section 36, T15N, R14W. The project area is drained by dry draws and one ephemeral draw with no continuous surface flow to the Blackfoot River. Elevation ranges from $3800 \mathrm{ft}$ at the Blackfoot River, to about $4600 \mathrm{ft}$.

The Blackfoot River watershed is a mixed ownership of State Trust Lands, Private, Plum Creek and BLM. The ephemeral draw in the project area in Section 36, $\mathrm{T} 15 \mathrm{~N}, \mathrm{R} 14 \mathrm{~W}$, originates on Plum Creek land, flows through State land and then returns to Plum Creek Land in Section 1, T14N, R14W. Impacts as a result of past harvest activities were observed to be low. Some old skid trails were present, but were well vegetated and stable. 
There is currently a conservation easement in Section 36 between the Montana DNRC and the Montana Department of Fish, Wildlife and Parks, which agrees to restricted activities in a portion of section $36 \mathrm{~T} 15 \mathrm{~N}, \mathrm{R} 14 \mathrm{~W}$. The easement states there is a "limited management zone (LMZ)" along the Blackfoot River where according to Section II., 8, tree cutting is prohibited unless it is done for the purpose of the following: 1 . cutting trees which are a hazard; 2 . removing diseased trees; or 3. to control insect infestations of immediate threat to adjacent timber. The existing road, where located within the LMZ, would be used as part of the haul route. Clearing would be allowed along the road, but restricted to a bare minimum. Also, under the LMZ restrictions, no skid trails or landings would be permitted within the LMZ. The LMZ extends beyond the Streamside Management Zone (SMZ) buffer.

\subsubsection{Water Quality}

\section{Water Regulatory Framework}

The Blackfoot River is a B-1 Classified Stream in the Montana Surface Water Quality Standards. The B-1 classification is for waters that are considered suitable for domestic use after conventional treatment, as well as recreation, swimming and bathing. They are also suitable for growth and propagation of salmonid fish and other associated aquatic life, waterfowl, furbearers, agricultural and industrial water supplies. Another criteria for a B-1 classification is; no increases are allowed above naturally occurring concentrations of sediment, settleable solids, oils or floating solids, which will or are likely to create a nuisance or render the waters harmful, detrimental or injurious to public health, recreation, safety, welfare, livestock, wild animals, birds, fish, or other wildlife.

The Blackfoot River in Section 36 is listed on the 1996 list for siltation and nutrients. It was listed on the 2000 list for nutrients and temperature. It is scheduled for reassessment under the 2005 TMDL list (as per conversation with George Mathieus).

Existing road densities in the project area are moderate, with approximately 5.63 miles of road in Section 36. Not all roads in the project area meet BMP's. There are some sections of road that have rutting and would require additional drainage. There is a short segment of haul route in the project area that is within approximately $75 \mathrm{ft}$ of the Blackfoot River for a distance of approximately 250 $\mathrm{ft}$. This segment of road has insufficient drainage and is easily rutted during runoff rain events. This portion of the road is on private property and receives private and DNRC administrative use only. The proposed action would not include the use of this road if authorization were acquired to use an alternate segment.

There is a bridge on private land, which is currently part of the haul route under the proposed action. The existing bridge is a steel Big $\mathrm{R}$ bridge, which is set on top of an old rotten wooden bridge. The foundation of the bridge is deteriorating 
and safety for long-term heavy truck traffic is questionable.

\subsubsection{Soils}

\section{$\underline{\text { Geology }}$}

Refer to Geology (Appendix A, Figure A-6) and Soils Map (Appendix A, Figure A-7) for project area Geology.

The project area is located on low to moderate slopes with some limited areas of steep slopes. There are no especially unique or unusual geological features located in the proposed project area. The geology in the project area is Alluvium and Missoula Belt Series. The Missoula Belt Series is a combination of argillites, siltites, and calcareous limestone derived from the Precambrian (Belt Series) meta-sediments bedrocks. The Alluvium located in the Valley Floor and lower elevations, is mainly alluvial deposits of gravels and cobbles derived from the belt rocks and localized lacustrine deposits of Glacial Lake Missoula silts (See geology Map).

\section{Soils}

There are some old skid trails in the project area from past harvest activities. However, these trails were observed to be stable and well vegetated. Although compaction was not measured, some level of compaction is expected from these trails. Soils in the project area are a combination of the soils listed in the following charts.

\section{Soil Chart 1}

\begin{tabular}{|c|c|c|c|c|}
\hline Map Unit & $\begin{array}{l}\text { Annual } \\
\text { Precipitation }\end{array}$ & Surface Layer & Subsoil Layer & Drainage Class \\
\hline $\begin{array}{l}43 \text { Glaciercreek } \\
\text { Varient- } \\
\text { Galiercreek } \\
\text { Complex 4-20\% } \\
\text { slopes }\end{array}$ & $22-30$ Inches & $\begin{array}{l}\text { Glaciercreek - } \\
\text { Shallow } 0-2 \text { " } \\
\text { gravelly silt loam } \\
\text { Glaciercreek } \\
\text { Varient- } \\
\text { Deep 0-9" fine sandy } \\
\text { loam }\end{array}$ & $\begin{array}{l}\text { Glaciercreek- Deep } \\
>60 " \text { extremely } \\
\text { gravelly loamy course } \\
\text { sand over extremely } \\
\text { gravelly course sand } \\
\text { Glaciercreek Varient } \\
\text { Deep }>60 " \text { fine sandy } \\
\text { loam over extremely } \\
\text { cobbly fine sandy loam }\end{array}$ & $\begin{array}{l}\text { Glaciercreek- } \\
\text { Excessively drained } \\
\text { Glaciercreek Varient- } \\
\text { somewhat excessively } \\
\text { drained }\end{array}$ \\
\hline $\begin{array}{l}75 \text { Perma Gravelly } \\
\text { Loam } 0-4 \% \text { slopes }\end{array}$ & 15-19 Inches & $0-6$ " Gravelly loam & $\begin{array}{l}\text { Deep }>40 " \text { gravelly } \\
\text { sandy loam over } \\
\text { extremely gravelly } \\
\text { loamy sand }\end{array}$ & $\begin{array}{l}\text { Somewhat excessively } \\
\text { drained }\end{array}$ \\
\hline $\begin{array}{l}77 \text { Perma Stony } \\
\text { Loam } 4-12 \% \text { slopes }\end{array}$ & 15-19 Inches & $0-6$ " Stony loam & $\begin{array}{l}\text { Deep }>40 " \text { gravelly } \\
\text { sandy loam over } \\
\text { extremely gravelly } \\
\text { loamy sand }\end{array}$ & $\begin{array}{l}\text { Somewhat excessively } \\
\text { drained }\end{array}$ \\
\hline $\begin{array}{l}\text { 99 Sharrott Rock } \\
\text { Outcrop Complex } \\
\text { 4-30\% slopes }\end{array}$ & 17-25 Inches & $0-4$ " Gravelly loam & $\begin{array}{l}\text { Shallow 4-15"Very } \\
\text { gravelly loam over } \\
\text { extremely gravelly } \\
\text { loam }\end{array}$ & Well drained \\
\hline $\begin{array}{l}\text { 101 Tally Variant } \\
\text { Sandy Loam 0-4\% } \\
\text { slopes }\end{array}$ & 15-19 Inches & $\begin{array}{l}\text { Deep 0-10" Sandy } \\
\text { Loam }\end{array}$ & $\begin{array}{l}\text { Deep }>40^{\prime \prime} \text { Loamy } \\
\text { sand over gravelly } \\
\text { sand }\end{array}$ & $\begin{array}{l}\text { Somewhat excessively } \\
\text { drained }\end{array}$ \\
\hline $\begin{array}{l}102 \text { Tevis Gravelly } \\
\text { Loam } 30-60 \% \\
\text { slopes }\end{array}$ & $25-40$ Inches & $\begin{array}{l}\text { Shallow 0-3" gravelly } \\
\text { loam }\end{array}$ & $\begin{array}{l}\text { Deep }>40 \text { " extremely } \\
\text { gravelly sandy loam }\end{array}$ & $\begin{array}{l}\text { Somewhat excessively } \\
\text { drained }\end{array}$ \\
\hline
\end{tabular}




\begin{tabular}{|l|l|l|l|l|}
\hline $\begin{array}{l}\text { 105 Totelake } \\
\text { Gravelly Loam 2- } \\
\text { 8\% slopes }\end{array}$ & $15-20$ Inches & $0-7$ " Gravelly loam & $\begin{array}{l}\text { Deep >40" gravelly } \\
\text { sandy loam over } \\
\text { gravelly loamy sand }\end{array}$ & Excessively drained \\
\hline $\begin{array}{l}\text { 133 Winkler } \\
\text { Gravelly Loam, } \\
\text { Cool, 30-60\% } \\
\text { slopes }\end{array}$ & $17-30$ Inches & $\begin{array}{l}\text { Shallow 0-3" } \\
\text { gravelly loam }\end{array}$ & $\begin{array}{l}\text { Deep }>40^{\prime \prime} \text { extremely } \\
\text { gravelly sandy loam }\end{array}$ & $\begin{array}{l}\text { Somewhat excessively } \\
\text { drained }\end{array}$ \\
\hline $\begin{array}{l}\text { 134 Winkler } \\
\text { Rubble Land } \\
\text { Complex 50-80\% } \\
\text { slopes }\end{array}$ & $17-24$ Inches & $\begin{array}{l}\text { Shallow 0-3" very } \\
\text { gravelly sandy loam }\end{array}$ & $\begin{array}{l}\text { Deep }>40^{\prime \prime} \text { extremely } \\
\text { gravelly sandy loam }\end{array}$ & $\begin{array}{l}\text { Somewhat excessively } \\
\text { drained }\end{array}$ \\
\hline $\begin{array}{l}\text { 135 Winkler Cool } \\
\text { Rock Outcrop } \\
\text { Complex, 50-80\% } \\
\text { slopes }\end{array}$ & $17-30$ Inches & $\begin{array}{l}\text { Shallow 0-3" } \\
\text { gravelly loam }\end{array}$ & $\begin{array}{l}\text { Deep >40" extremely } \\
\text { gravelly sandy loam }\end{array}$ & $\begin{array}{l}\text { Somewhat excessively } \\
\text { drained }\end{array}$ \\
\hline
\end{tabular}

Soil Chart 2

\begin{tabular}{|c|c|c|c|c|c|c|}
\hline Map Unit & $\begin{array}{l}\text { Parent } \\
\text { Material }\end{array}$ & $\begin{array}{l}\text { Soil Moisture } \\
\text { Water } \\
\text { Holding } \\
\text { Capacity }\end{array}$ & $\begin{array}{l}\text { Erosion } \\
\text { Hazard }\end{array}$ & $\begin{array}{l}\text { Displacement } \\
\text { Hazard }\end{array}$ & $\begin{array}{l}\text { Compaction } \\
\text { Hazard }\end{array}$ & Notes \\
\hline $\begin{array}{l}43 \text { Glaciercreek } \\
\text { Varient- } \\
\text { Galiercreek } \\
\text { Complex } 4-20 \% \\
\text { slopes }\end{array}$ & $\begin{array}{l}\text { Glaciercreek- } \\
\text { Glacial } \\
\text { Outwsash } \\
\text { Glaciercreek } \\
\text { Varient- } \\
\text { formed in } \\
\text { Alluvium over } \\
\text { Glacial } \\
\text { Outwash }\end{array}$ & $\begin{array}{l}\text { Glaciercreek- } \\
2.7 \text { Inches } \\
\text { Glaciercreek } \\
\text { Varient- } 6.1\end{array}$ & Moderate & Moderate & Moderate & $\begin{array}{l}\text { Shallow soils } \\
\text { and droughty }\end{array}$ \\
\hline $\begin{array}{l}75 \text { Perma } \\
\text { Gravelly Loam } \\
0-4 \% \text { slopes }\end{array}$ & Alluvium & 4.4 inches & Low & Low & Low/Moderate & $\begin{array}{l}\text { Avoid } \\
\text { displacement } \\
\text { of surface } \\
\text { soils }\end{array}$ \\
\hline $\begin{array}{l}77 \text { Perma Stony } \\
\text { Loam } 4-12 \% \\
\text { slopes }\end{array}$ & Alluvium & 4.5 inches & Low & Low & Low/Moderate & $\begin{array}{l}\text { Avoid } \\
\text { displacement } \\
\text { of surface } \\
\text { soils }\end{array}$ \\
\hline $\begin{array}{l}99 \text { Sharrott Rock } \\
\text { Outcrop } \\
\text { Complex } 4-30 \% \\
\text { slopes }\end{array}$ & $\begin{array}{l}\text { Residuum } \\
\text { derived from } \\
\text { argillite and } \\
\text { quartzite }\end{array}$ & 1.5 inches & $\begin{array}{l}\text { High } \\
\text { Shorten } \\
\text { distance for } \\
\text { drainage } \\
\text { features }\end{array}$ & $\begin{array}{l}\text { High } \\
\text { Avoid } \\
\text { displacement } \\
\text { of surface } \\
\text { soils }\end{array}$ & Moderate & $\begin{array}{l}\text { Shallow } \\
\text { surface soils, } \\
\text { avoid } \\
\text { displacement } \\
\text { of surface } \\
\text { soils } \\
\end{array}$ \\
\hline $\begin{array}{l}101 \text { Tally } \\
\text { Variant Sandy } \\
\text { Loam } 0-4 \% \\
\text { slopes }\end{array}$ & Alluvium & 4.9 inches & Low & Moderate & Moderate & $\begin{array}{l}\text { Check } \\
\text { moisture } \\
\text { levels before } \\
\text { operations } \\
\text { begin }\end{array}$ \\
\hline $\begin{array}{l}102 \text { Tevis } \\
\text { Gravelly Loam } \\
30-60 \% \text { slopes }\end{array}$ & $\begin{array}{l}\text { Colluvium } \\
\text { derived from } \\
\text { argillite and } \\
\text { quartzite }\end{array}$ & 4.9 inches & $\begin{array}{l}\text { High } \\
\text { Shorten } \\
\text { distance for } \\
\text { drainage } \\
\text { features }\end{array}$ & Moderate & Low & $\begin{array}{l}\text { Check } \\
\text { moisture } \\
\text { levels before } \\
\text { operations } \\
\text { begin }\end{array}$ \\
\hline $\begin{array}{l}105 \text { Totelake } \\
\text { Gravelly Loam } \\
2-8 \% \text { slopes }\end{array}$ & Alluvium & 3.1 inches & Low & Low & Moderate & $\begin{array}{l}\text { Intermittent } \\
\text { ash layer in } \\
\text { the top } 2-4 \text { " of } \\
\text { the surface } \\
\text { layer in some } \\
\text { pedons }\end{array}$ \\
\hline $\begin{array}{l}133 \text { Winkler } \\
\text { Gravelly Loam, } \\
\text { Cool, 30-60\% } \\
\text { slopes }\end{array}$ & $\begin{array}{l}\text { Colluvium } \\
\text { derived from } \\
\text { argillite and } \\
\text { quartzite }\end{array}$ & 3.0 inches & Moderate & High & Low/Moderate & $\begin{array}{l}\text { Limit Tractor } \\
\text { slopes to less } \\
\text { than } 45 \%\end{array}$ \\
\hline $\begin{array}{l}134 \text { Winkler } \\
\text { Rubble Land } \\
\text { Complex 50- } \\
80 \% \text { slopes }\end{array}$ & $\begin{array}{l}\text { Colluvium } \\
\text { derived from } \\
\text { argillite and } \\
\text { quartzite }\end{array}$ & 3.1 inches & High & High & High & $\begin{array}{l}\text { Rock may } \\
\text { limit roads } \\
\text { and planting }\end{array}$ \\
\hline $\begin{array}{l}135 \text { Winkler } \\
\text { Cool Rock } \\
\text { Outcrop } \\
\text { Complex, 50- } \\
80 \% \text { slopes } \\
\end{array}$ & $\begin{array}{l}\text { Colluvium } \\
\text { derived from } \\
\text { argillite and } \\
\text { quartzite }\end{array}$ & 3.0 inches & High & High & High & $\begin{array}{l}\text { Rock may } \\
\text { limit roads } \\
\text { and planting }\end{array}$ \\
\hline
\end{tabular}




\subsubsection{Cold Water Fisheries}

The Blackfoot River is the only fish bearing body of water in the analysis area. The Blackfoot River is highly valued as a productive cold water fishery supporting populations of bull trout (Salvelinus confluentus), rainbow trout (Onchorynchus mykiss), and brown trout (Salmo trutta). Bull trout are listed under the Endangered Species Act as threatened, and westslope cutthroat trout are considered a "species of special concern". As mentioned above, the Blackfoot River in Section 36 is listed on the 1996 list for siltation and nutrients. It was listed on the 2000 list for nutrients and temperature.

Riparian habitat conditions in this section of the Blackfoot River were observed to be in fair condition. Banks stability and integrity was observed to be in fair condition, with some areas of bank instability present due to erosion and sloughing. Sufficient canopy cover along banks, which provides adequate levels of thermal protection is absent in some reaches of the Blackfoot in the project area.

There is a bridge crossing on Chamberlain Creek, located on the haul route as mentioned above in the water quality section. Although this bridge is in a state of deterioration, there are no existing effects on fisheries habitat. However, longterm impacts could be severe, if rotten abutments give way and large amounts of sediment are delivered to the stream channel.

\subsubsection{Noxious Weeds}

Noxious weeds occurring in the project area are Spotted knapweed (Centaura maculosa) and spot infestations of Canada thistle (Cirsium arvense). Spotted knapweed occurs along the roadside and in spots of the forested area. There are small patches of leafy spurge (Euphorbia esula) located on the lower flats. Leafy spurge flea beatles (Apthonia Spp.) have been released to help reduce the current infestation. Access is currently restricted to the project area, which has helped to reduce the risk of increased weed infestations.

\subsubsection{Human Environment}

\subsubsection{Recreation Opportunity, and Quality}

Public recreation access is limited to individuals with private property access, by boat, or walk in from bordering Plum Creek land. Due to difficulty with access, the main recreation use is by floaters and fishermen along the Blackfoot river.

Fishing and hunting opportunities exist within the project area. Fishing is popular along the Blackfoot river, primarily during the spring, summer and early fall. A fishing access site exists on the north side of the Blackfoot river (opposite from proposed activities) (see Appendix A, figure A-5). This access site primarily is used for a boat ramp facility by floaters during spring, summer 
and early fall. Fire-arms are prohibited within Section 36, Township 15 N., Range $14 \mathrm{~W}$., so hunting is limited to archery only.

\subsubsection{Disruption, Noise, and Dust}

The proposed access route would pass through private property. Public use of this road is prohibited. Only authorized use is permitted. Residents currently enjoy virtually no traffic. One segment of access route would pass within view of Russell Gates Park. The portion of this road segment, which is visible from Russell Gates Park, may not be used under the proposed action if permission is granted to use an alternate road segment.

Montana Highway 200 runs through the NW $1 / 4$ of this state section. Traffic noise associated with the highway is relatively constant.

Dust is created by public motorists on gravel portions of county road during excessively dry periods. The Powell County road department is responsible on that road for dust abatement if necessary.

Refer to Appendix A, Figure A-3 for road locations.

\subsubsection{Aesthetics}

Topography within the project area is consistent with mountainous topography common to the area. The landscapes in the general area are influenced by glaciation with steep glaciated peaks and lower rolling ridges. The project area lies between two glacial moraines.

The Blackfoot River runs through the west $1 / 2$ of state section 36 . The river itself is free flowing with frequent riffles and meanders. The terrain gently slopes upward in a series of benches moving upward in elevation to the east from the river. These benches are moderately to heavily timbered with small, open parks. Timber stands on hillsides facing to the south and west generally are more open than those facing to the north and east. Slopes range from relatively flat (closer to the river) to roughly 70 percent with rocky outcrops (near mid slope in the southern portion of the section). A steep, north east facing rock scree slope faces Highway 200. It lies within the southeast $1 / 4$ of the northeast $1 / 4$ of the section. An existing, low standard road system is present. See Appendix A, Figure A-4 for a visual description.

Due to topography and distance the proposed harvest area would be clearly visible from Montana Highway 200. Sloping topography faces the highway and the nearest proposed harvest unit area would be as close as approximately 500 feet away. 
Recreational traffic (boating) is common along the Blackfoot river during the spring, summer and early fall. The proposed harvest units would be visible from the river, but to a lesser extent than the highway due to the low profile of the river level, the no-harvest corridor adjacent to the river (LMZ), and the benchy terrain.

Several DNRC cabin sites and a DNRC office site exist within the viewshed. The proposed harvest area would be visible from these sites.

The Russell Gates Park is located approximately 0.8 miles up-river from the project area. Topography within the proposed harvest area generally faces away from the park, but some visible effects of tree removal could be noticeable from the park.

\section{Analysis Methods}

The visual resource analysis was conducted by utilizing the Visual Management System (USDA 1977a, USDA 1977b, USDA 1980a, USDA 1980b), and the Scenery Management System (USDA 1995). Both of these were developed by the U.S. Forest Service and have been used to describe the existing conditions, effects of actions, and mitigations for projects. Information used in this analysis was gathered from field visits, analysis of photographs and seen area maps, and the study of landscape patterns in the area.

\section{Existing Scenic Integrity}

"Scenic integrity" has to deal with the "state of naturalness" or state of disturbance created by human activities or alterations". This project area has been inventoried as having a MODERATE scenic integrity level overall.

Areas with moderate scenic integrity "appear slightly altered, however, noticeable deviations to the landscape must remain visually subordinate to the overall viewed landscape".

\section{Visual Absorption Capacity}

This area was inventoried to determine its Visual Absorption Capacity or VAC. VAC is defined as the "physical ability of the land to support management activities and to maintain scenic integrity". Factors that aid in determination of the VAC are: the natural forms, lines, colors, and textures; the distance between the project area and the viewpoints; the estimated number of viewers; and the relative sensitivity of those viewers to the scenery around them.

As just stated, one of the factors that determines VAC is the distance between the project area and the viewpoints. This is generally categorized into three groups; foreground viewing (distances from the viewer's position out to around 2 mile), middle ground viewing (distances from 2 mile to 4 miles from the 
observer), and background viewing (distances greater than 4 miles from the viewer's position). A subgroup of foreground viewing is the detailed feature landscape within the first few hundred feet of the observer.

Often slope impacts the amount of VAC by enhancing any changes in form, line, color, or texture. In the simplest terms, the steeper the slope, the lower the VAC. This means that a harvest prescription that is barely visible on gentle sloping ground can be highly visible when on steep ground.

\section{$\underline{\text { Scenic Inventory }}$}

The inventory gathered includes viewing the project area from the intersection of Highway 200 and the Sperry Grade county road. The over-all view from traveling Highway 200 from Clearwater Junction at mile marker 33 to mile marker 35 was also assessed. Most of the site has moderate VAC and a small amount has low VAC.

\subsubsection{Conservation Easement}

A conservation easement between the Montana DNRC and the Montana DFWP exists. This conservation easement provides for the following limitations and practices to the entire portion of Section 36, Township 15 North, Range 14 West, east of the high water mark of the Blackfoot River.

1. Historical uses such as timber management, and the maintenance of existing right-of-way shall be permitted to continue, subject to the following:

a. Timber management practices shall be conducted with responsible, professional standards.

b. New roadways shall not be constructed except for the implementation of timber practices established with item " $a$ " above.

c. No active or inactive Bald eagle, golden eagle, osprey nest, other raptor nest (known or later identified), other raptor nesting habitat, or other vegetation within 660 Feet of any such nest during the nesting season shall be cut. Additionally, no crown trees or other overstory vegetation, including nesting trees themselves shall be cut within 330 Feet of any active or inactive raptor nest currently known or later identified at any time. However, during the non-nesting season, diseased trees may be cut and removed to abate infestation. 


\section{Limited Management Zone (LMZ)}

Immediately adjacent to the Blackfoot River (see Appendix A, figure A-3 for a more detailed description of the location and size of the LMZ), The following limitations on uses and practices as they pertain to the action alternative are described as follows:

a. The establishment of new, permanent roadways shall be prohibited.

b. Vehicle use shall be limited to use on existing rights of way by government agency personnel or parties having legal right to use the right of way.

c. There shall be no cutting of trees, standing, or, down, nor clearing of any existing vegetation, except to remove trees or vegetation which are a hazard, to remove diseased trees, or to control insect infestations of immediate threat to timber.

d. Broadcast application of herbicides, pesticides, and biocides, shall be prohibited.

e. Permission is granted for minimal existing road maintenance within the LMZ (Rebecca J. Dockter letter, Jan. 7, 2003, Project File).

- The absolute minimum number of seedling and sapling trees may be cut within the roadway as well as branches from larger trees, which would otherwise be damaged by vehicle traffic.

- Vehicle traffic is limited to the absolute minimum necessary to access timber adjacent to the LMZ. Vehicle traffic associated with the proposed timber sale in the remainder of section 36 will be allowed on the LMZ roadway only during periods when the ground is frozen and minimal road disturbance will occur. FWP will be provided the opportunity to consult in the field with DNRC and its contractor immediately prior to any tree cutting in the LMZ.

\subsubsection{Economics}

There is no current revenue being generated from the sale of timber on this section. The costs related to the administration of the forest product sales program are only tracked at the Land Office and statewide level. DNRC does not track project level costs for individual timber sales. An annual cash flow analysis is conducted on the DNRC forest product sales program. Revenue and costs are calculated by Land Office and Statewide. These revenue-to-cost ratios are a measure of economic efficiency. 
Table 3-6: Revenue - Cost ratios

$\begin{array}{llllll} & \text { FY00 } & \text { FY01 } & \text { FY02 } & \text { FY03 } & \text { FY04 } \\ \text { SWLO } & 2.36 & 2.69 & 2.57 & 1.61 & 2.74 \\ \text { State } & 2.78 & 1.62 & 1.75 & 1.75 & 1.82\end{array}$

\subsubsection{Cultural and Historic Resources}

The DNRC staff archeologist conducted an inventory of cultural resources of the Headquarters Timber Sale project area. During the course of that inspection, no cultural or paleontologic resources were identified. No additional archeological investigative work was recommended for this proposed undertaking (Patrick Rennie memo, March 14, 2005, Headquarters Timber Sale Project File).

\subsubsection{Vegetation}

\subsubsection{Natural Role of Wildfire}

Historic fire-caused disturbances in the project area were relatively uniform in their frequency and intensity. The predominant fire type that occurred in the project area had high-frequency and low-intensity and was most commonly associated with the ponderosa pine and dry Douglas-fir habitat types.

Warm, dry Douglas-fir and some ponderosa pine habitat types are the most common to the project area and are categorized as Fire Group 4 (Fischer and Bradley 1987). Historic fire frequencies were between 5-25 years on these sites (Fishcher and Bradley 1987).

Since the advent of aggressive wildfire suppression, stand conditions within the project area have resulted in an un-natural build-up of fuels. This is particularly true in the small to intermediate size-class Douglas-fir.

Some timber within the project area has been selectively harvested. Approximately 1.35 MMBF from 1969-1972, $200 \mathrm{MBF}$ in 1967, and 4.4 MMBF from 1954-1957 of timber was harvested. These treatments were helpful in reducing some fuels. Since these treatments, shade tolerant Douglasfir have been allowed to grow and re-establish themselves as ladder fuels. Overstocked conditions as well as an abundance of ladder fuels are fairly common throughout the project area. However, small natural, grass covered openings still exist and are randomly distributed as well. Over time without disturbance, these openings would be expected to fill in.

\subsubsection{Forest Fragmentation}

Forest fragmentation and its relationship to maintaining biological diversity has been a primary concern for nearly two decades (Harris 1984). Forest fragmentation occurs in an incremental process. Forest cover is removed, and 
remaining forested patches of various ages and structures become smaller and more isolated by dissimilar habitats (Hunter 1997, Harris 1984). A mix of landowners, varied management objectives among companies and agencies charged with land management responsibilities or development, and diverse forest practices can all influence the rate and extent of fragmentation on a given landscape. As forested patches become smaller and more isolated, they tend to provide habitat for fewer species. Small, isolated patches also tend to have greater extinction rates than large habitat patches (Harris 1984), have greater amounts of edge habitat (Paton 1994), and are less beneficial as travel corridors and interior forest habitat (Powell and Zielinski 1994). Additional edge created as forest patches become more fragmented can promote increased predation and reduced survival for some species of wildlife (Heijl and Paige 1994, Paton 1994, Vander Haegen and DeGraaf 1996).

Because wildfires were a primary disturbance factor historically in shaping the forests of Western Montana (Losensky 1997, Arno et al. 1995, Fischer and Bradley 1987, Losensky 1987, Gruell 1983) substantial portions of forested landscapes were fragmented naturally (Gruell 1983, Hart 1994). Fires were particularly commonplace on dry sites. Consequently, many native wildlife species evolved with substantial habitat that occurred in relatively small, isolated patches. Although a relatively high degree of fragmentation probably occurred and was natural under historic disturbance regimes in the Seeley-Swan landscape, the number of forested patches has increased and the mean patch size has decreased dramatically since the 1930's (Hart 1994). Therefore, forested habitat patches at the present have become more isolated, maintain over twice the edge, and are less connected to one another at the landscape scale.

Coniferous forests in the vicinity of the proposed project area, which is located at the southernmost end of the Seeley-Swan Landscape (Hart 1994), likely ranged from open ponderosa pine/Douglas-fir savannahs and parks to dense, closed canopy lodgepole and mixed conifer forests. Most of the project area probably did not provide extensive areas of forested habitat.

\subsubsection{Leave Trees}

Following selective tree harvest practices, windthrow (or blowdown) may occur. This often results when individual trees are suddenly exposed to high wind after protection of neighboring, standing trees is reduced. Often, tree species having shallow root systems, trees growing in unstable soils, trees growing on exposed ridge tops and trees with decaying root systems are the most susceptible to windthrow. Leave tree selection should consider these factors.

Existing stand conditions include both open-grown and grouped trees. Commercial tree species include Douglas-fir, Ponderosa pine and Western larch. All three of these species tend to have stable root systems, but of these, three species, Western larch and Ponderosa pine have superior wind-firm 
characteristics. Many small or intermediate sized trees exist. These trees are often Douglas-fir. Stands proposed to be harvested are on stable soils. The majority of the proposed harvest stands occupy relatively flat topography. Those stands on the higher elevations and on steeper slopes would have the most exposure to high wind events.

\subsubsection{Natural Tree Regeneration}

Even-aged harvest treatments are generally intended for the purpose of establishing a new age class and eventually replacing the current age class. Uneven-aged harvest treatments are not always associated with establishing a new age class. These types of uneven aged treatments can be used to produce a semblance of even-aged management. Natural ponderosa pine regeneration would be expected to occur where areas are opened to a basal area of around 25 square feet per acre (Ffolliott et. al. 2000). Often, signs of natural regeneration following harvest may not occur for long periods of time depending on factors such as cone production and growing conditions following harvest.

\subsubsection{Wildlife}

\subsubsection{Threatened and Endangered Species}

\subsection{Bald Eagle (Federally threatened)}

Bald eagles typically nest and roost in large diameter trees within 1 mile of open water. They are sensitive to a variety of human caused disturbances, ranging from residential activities to resource use and heavy equipment operation, among others (Montana Bald Eagle Working Group 1994). Bald eagle response to such activities may range from spatial and temporal avoidance of disturbance activities to total reproductive failure and abandonment of breeding areas (MBEWG 1994). While foraging, they typically perch within $500 \mathrm{~m}$ of shoreline habitat (Mersmann 1989); and roost in trees ranging in diameter from 12 to 39 inches and 49 to 200 feet in height (Stalmaster 1987). Eagles are generally associated with aquatic foraging habitat. However, roost trees are located away from houses and roads throughout their range (Buehler 2000). The affected School Trust parcel is located within 0.25 mile of a bald eagle nest cluster ( 5 nests Sperry Grade Eagle Territory) for which the Montana Bald Eagle Working Group has records dating back to 1979 . The territory has averaged 1 to 2 young fledged for the past 5 years, and nesting occurred in 2004. This territory was established after Highway 200 and the Russell Gates Campground were established. Thus, eagles inhabiting this territory are accustomed to varying levels of disturbance (motorized activity on Hwy 200 and recreational use along the Blackfoot River and the campground) within 0.25 mile of several nest trees. The proposed haul route would be approximately 0.25 mile from the 2004 nest, and within 0.15 mile of all 5 known nests for this territory. A 
field visit on June 1, 2004 discovered that one of the 5 historic nest trees may have blown over.

\subsection{Grizzly Bear (Federally threatened)}

Grizzly bears are the largest terrestrial predators in North America, feasting upon deer, rodents, fish, roots and berries, as well as a wide assortment of vegetation (Hewitt and Robbins 1996). Depending upon climate, abundance of food, and cover distribution, home ranges for male grizzly bears in northwest Montana can range from $60-500 \mathrm{mi}^{2}$ (Waller and Mace 1997). The search for food drives grizzly bear movement, with bears moving from low elevations in spring to higher elevations in fall, as fruits ripen throughout the year. However, in their pursuit of food, grizzly bears can be negatively impacted through open roads (Kasworm and Manley 1990). Such impacts are manifested through habitat avoidance, poaching, and vehicle collisions.

The project area is approximately 8.5 miles south of the Northern Continental Divide Ecosystem grizzly bear recovery area. The nearby Blackfoot Clearwater Wildlife Management Area (hereafter Game Range) and Baldy Mountain, have had repeated grizzly bear activity in recent years (J. Jonkel, MT FWP, personal communication, 2003). Thus, the proposed project area may be part of one or more grizzly bear home ranges. Therefore, the cumulative effects analysis area for grizzly bears encompasses 655 square miles (419,382 acres), including the Game Range and Baldy Mountain.

Grizzly bears are known to be more vulnerable to human interaction in areas with high open road densities or ineffective road closures. Currently there are 1.08 miles of open road per square mile (simple linear calculation; 710 miles of open road), and 2.9 total miles of road per square mile (1,898 miles of road), within the 655 square mile grizzly bear analysis area. Within the project area, there are approximately 1.06 miles of open road per square mile (including Highway 200), and approximately 5.63 miles of total road per square mile (simple linear calculation). Many of the "closed" roads south of the Blackfoot River are considered as such largely due to efforts by adjacent private landowners, rather than locked gates. The land management on adjacent lands maintains private roads that provide access to the project area. The current ranch manager for the Knob and Kettle Ranch has been in his position for the past 15 years and lives on-site. The roads of concern (i.e. whether they should be considered "closed" due to the absence of year-round locked gates) do have gates that are locked when nobody is present. These roads also pass by the ranch manager's and owner's homes. The only access (foot only) is to approximately 6 individuals during archery season, and these individuals must call ahead for notification. Over the past 15 years, there has been no motorized trespassing (Pat Brock, owner, personal communication, December 2003). Additionally, the Knob and Kettle Ranch have the grazing license for the project area (110 AUM), but have not grazed livestock on the parcel for several years. Thus, motorized access onto the affected parcel, 
south of the Blackfoot River, is controlled by, and limited to, the adjacent landowner and licensee, the Knob and Kettle Ranch.

Also on the affected parcel are $10 \mathrm{cabin} /$ home site leases (west of the Blackfoot River) and a conservation license with Montana Department of Fish, Wildlife \& Parks (MT DFWP). The conservation license prohibits timber harvesting within a defined area adjacent to the Blackfoot River. Thus, guaranteeing screening cover for grizzly bears along the river.

\subsection{Gray Wolf (Federally threatened)}

Wolves were recently classified as threatened under the Endangered Species Act. Cover, and road and prey densities likely have some influence on wolves (road densities reported under grizzly bear). For cumulative effects analysis, the analysis area will be the same as that of the grizzly bear. Wolf activity within the analysis area is restricted to the Blanchard pack, located approximately 4 miles west of the project area, near Clearwater Junction (U. S. Fish and Wildlife Service 2002). Mule deer, white-tailed deer, elk, and moose are known to use the area. The adjacent Game Range and surrounding area are also known to be a significant winter range for $600-1000$ resident and migratory elk, and $700-1000$ resident and migratory mule deer. Currently, no known wolf den or rendezvous site is located within 1 mile of the project area.

\subsubsection{Sensitive Species}

\subsection{Pileated Woodpecker}

The pileated woodpecker is one of the largest woodpeckers in North America (15-19 inches in length), feeding primarily on carpenter ants (Camponotus spp.) and woodboring beetle larvae (Bull and Jackson 1995). The pileated woodpecker nests and roosts in larger diameter snags, typically in mature to old-growth forest stands (McClelland et al. 1979, Bull et al.

1992)(McClelland et al. 1979). Due primarily to its large size, pileated woodpeckers require nest snags averaging 29 inches $\mathrm{dbh}$, but have been known to nest in snags as small as 15 inches dbh in Montana (McClelland 1979). Pairs of pileated woodpeckers excavate 2-3 snags for potential nesting sites each year (Bull and Jackson 1995). Snags used for roosting are slightly smaller, averaging 27 inches dbh (Bull et al. 1992). Overall, McClelland (1979) found pileated woodpeckers to nest and roost primarily in western larch, ponderosa pine, and black cottonwood. The primary prey of pileated woodpeckers, carpenter ants, tend to prefer western larch logs with a large end diameter greater than 20 inches (Torgersen and Bull 1995). Thus, pileated woodpeckers generally prefer western larch and ponderosa pine snags $>15$ inches dbh for nesting and roosting, and would likely feed on downed larch logs with a large end diameter greater than 20 inches. 
The affected area is predominately of the Douglas-fir/snowberry habitat type (Pfister et al. 1977), in which the stands are $>50 \%$ ponderosa pine, followed by Douglas-fir in stand composition (Stand Level Inventory database). In general, these stands exhibit 2 cohorts of trees: a ponderosa pine overstory with a Douglas-fir understory, which likely resulted from $>70$ years of fire suppression (Fig. 1). The preponderance of ponderosa pine $>17$ inches dbh would provide snags, snag recruits, and foraging substrate for pileated woodpeckers. Within the affected parcel, there are approximately 463 acres that are predominately ponderosa pine or western larch, with average stand diameter $\geq 15$ inches dbh that would be considered suitable pileated woodpecker habitat (SLI database).

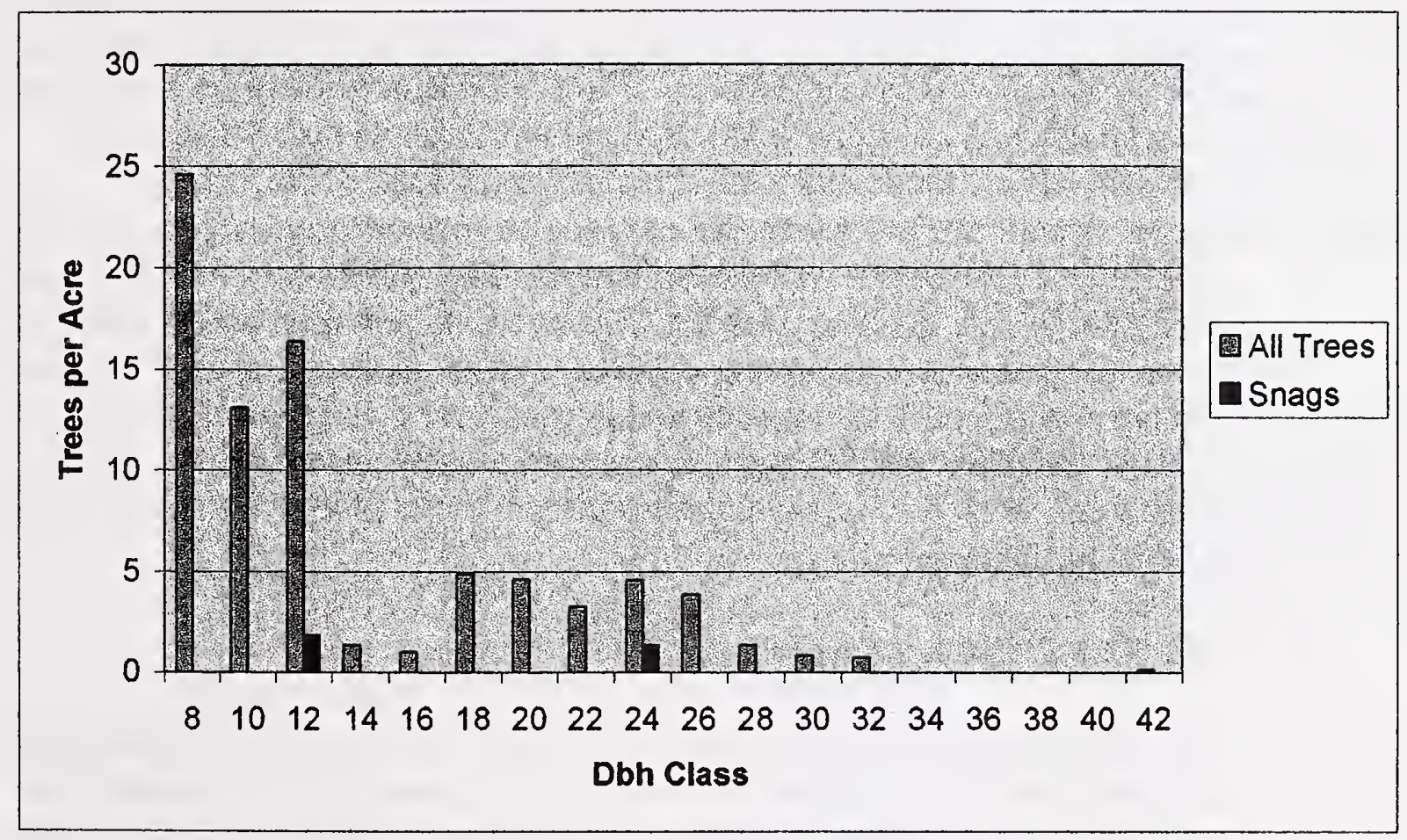

Figure 1. Generalized diameter distribution for stands within the affected parcel (section 36, T15N, R14W). Diameter distribution based off of a timber cruise for proposed harvest unit 36-2, using a $20 \mathrm{BAF}$ prism on 14 plots. Generally, there is a bimodal distribution indicative of 2 tree cohorts: a ponderosa pine overstory with an understory of Douglas-fir.

\subsection{Black-backed Woodpecker}

The black-backed woodpecker is an irruptive species that forages opportunistically on outbreaks of wood boring beetles primarily in recently burned habitats, and to a lesser degree in unburned habitats. It is also considered to be a sensitive species in Montana. Although the black-backed woodpecker's nesting and foraging requirements are thought to be tightly linked with burned areas, it does nest and forage in unburned forest in response to insect outbreaks (Hutto 1995, Hutto 1995, Bull et al. 1986). 
Burned forests tend to be used immediately after burns occur (approximately 1 - 5 years). Large, densely stocked non-salvaged stands with an abundance of trees greater than or equal to 12 inches dbh appear to provide the greatest benefit to black-backed woodpeckers for foraging and nesting. Black-backed woodpeckers are also found in green forests with high levels of insect activity.

The extensive and intensive wildfires of western Montana in 2003 created large amounts of potentially suitable habitat that will be available for blackbacked woodpeckers at the landscape scale. Because of the close relationship of black-backed woodpeckers and wildfire, the analysis area was defined as an area inclusive of four major fires near the project area: the Boles Meadow, Dirty Ike, Mineral-Primm, and Stuart Peak fires. Current information regarding burn intensity was unavailable for all fires except the Dirty Ike fire. However, these fires likely created sizable acreages of suitable black-backed woodpecker habitat. The 17,637-acre Mineral-Primm Complex is located largely within the Rattlesnake Wilderness area. Thus, those portions of this fire occurring in the wilderness area would remain unharvested. The 4,466 acre Boles Meadow Fire occurred largely on USFS and Plum Creek lands, with potential black-backed woodpecker habitat on USFS lands. On the Dirty Ike fire, 776 acres burned, with approximately 203 acres in stand replacement fire. However, those acres that burned with stand replacement intensity on the Dirty Ike fire are being salvage logged by the DNRC (see Dirty Ike Salvage Environmental Assessment; DNRC 2003). The Stuart Peak fire burned approximately 577 acres on USFS land 3 miles SW of the Mineral-Primm Fire.

\subsection{Flammulated Owl}

The flammulated owl is a tiny forest owl that inhabits warm-dry ponderosa pine and cool-dry Douglas-fir forests in the western United States and is a secondary cavity nester. Nest trees in 2 Oregon studies were 22-28 inches $\mathrm{dbh}$ (McCallum 1994). Habitats used have open to moderate canopy closure (30 to 50\%) with at least 2 canopy layers, and are often adjacent to small clearings. It subsists primarily on insects and is considered a sensitive species in Montana. Periodic underburns may contribute to increasing habitat suitability for flammulated owls because low intensity fires would reduce understory density of seedlings and saplings, while periodically stimulating shrub growth. Within the project area there are approximately 627 acres of flammulated owl preferred habitat types.

\subsection{Fisher}

The fisher is a medium-sized animal belonging to the weasel family. Fishers prefer dense, lowland spruce-fir forests with high canopy closure, and avoid forests with little overhead cover and open areas (Powell 1978, Powell 1978, 
Powell 1977, Kelly 1977, Powell 1977, Kelly 1977, Clem 1977, Coulter 1966, Coulter 1966). For resting and denning, fishers typically use hollow trees, logs and stumps, brush piles, and holes in the ground (Coulter 1966, Powell 1977).

Within a 1-mile radius of the project area, there are approximately 154 acres of fisher preferred habitat types on School Trust parcels. Of these acres, approximately 123 acres occur within the project area, and approximately 34 acres would be considered under the proposed harvest.

\subsection{Harlequin Duck}

Harlequin ducks require white-water streams with boulder and cobble substrates for nesting and breeding. Harlequins usually nest under bushes along rocky shores that are adjacent to the rapids of mountain streams. They typically dive 3 to 5 feet in the swift currents in search of food along the streambed. Typical food items are primarily animal food, consisting of: crustaceans, mollusks, insects, and echinoderms and fish (Bellrose 1980). Thus, water quality is an issue for harlequin ducks so that they can continue to find food during the breeding season.

Since 19893 nests have been located along the Blackfoot River and an unnamed tributary (Montana Natural Heritage Database). The nest located on the unnamed tributary is located upstream of the project area, and should thus, be unaffected by the proposed action. The 2 other nests are located in section $4, \mathrm{~T} 14 \mathrm{~N}, \mathrm{R} 14 \mathrm{~W}$, and section $25, \mathrm{~T} 14 \mathrm{~N}, \mathrm{R} 15 \mathrm{~W}$, along the Blackfoot river and downstream of the proposed action. Thus, because of the prevalence of harlequin ducks along the Blackfoot River, effects of the proposed action on this species will be analyzed.

\subsubsection{Big Game}

\subsection{Moose}

Moose are the largest ungulate in North America, distributed throughout Alaska, Canada, and many of the border states. In general, moose habitat includes: areas of abundant high-quality winter browse; shelter areas that allow access to food; isolated sites for calving; aquatic feeding areas, young forest stands with deciduous shrubs and forbs for summer feeding; mature forest that provides shelter from snow or heat; and mineral licks (Thompson and Stewart 1998). As such, much of the project area receives use by moose. The analysis area for moose corresponds with an 85,733 acre winter range mapped by MT DFWP, of which approximately 405 acres overlaps the affected School Trust parcel. There are approximately 33,397 acres of seedtree/shelterwood harvest, clearcuts, and grassland within the analysis area, with approximately 27.25 acres of these acres located in both the project area and analysis area. 


\subsection{Elk, White-tailed, and Mule Deer}

The project area is used extensively by the Chamberlain elk herd, whitetailed deer, and mule deer (Burcham et al. 1998). Each species has slightly different habitat requirements. Elk and deer generally avoid open roads, with elk becoming more tolerant of closed roads in the area over time (Lyon 1998). Densely stocked thickets of conifer regeneration and overstocked mature stands provide thermal protection and hiding cover for deer and elk in winter, which can reduce energy expenditures and stress associated with cold temperatures, wind, and human-caused disturbance. Additionally, extensive (e.g., $\geq 250$ acres) areas of forest cover $\geq 0.5$ miles from open roads serve as security for elk. Thus, removing cover that is important for wintering deer through forest management activities can increase their energy expenditures and stress in winter. Reductions in cover could ultimately result in a reduction in winter range carrying capacity and subsequent increases in winter mortality within local deer herds.

Within the project area, there are currently approximately 4.57 miles of closed road per square mile (see explanation in 3.2.4.1.2 under grizzly bears; simple linear calculation), and 143 acres of forest cover that could be used for snow-intercept cover. There are approximately 97 acres of forest cover within the project area that could currently be used for security cover during the hunting season.

The cumulative effects analysis area encompasses approximately 38.6 square miles, and corresponds to the seasonal home range of the Chamberlain elk herd (Burcham et al. 1998). Within the analysis area, there are approximately 15 miles of open road, for a total of 0.39 miles of open road per square mile (simple linear calculation), and at least 152 miles of total road, for a total of at least 3.95 miles of total road per square mile (simple linear calculation). There are 11,781 acres of forest cover that could be used for snow-intercept cover, and approximately 9,259 acres (39\% of cumulative effects analysis area) of forest cover that could be used for security cover during the hunting season. 
Headquarters Timber Sale - EA

\section{CHAPTER 4}





\subsection{Chapter 4: Environmental Consequences}

\subsection{Introduction}

Chapter 4: Environmental Consequences forms the scientific and analytic basis for the summary comparison of effects presented in Chapter 2, 2.7.3, Table 2-5 of this EA. This chapter describes the predicted effects of the two alternatives. This chapter focuses on the following effects:

- Direct effects

- Indirect effects

- Cumulative effects

This chapter has the two following major sections:

- Predicted Attainment of the Project Objectives of All Alternatives

- Predicted Effects on Relevant Affected Resources of All Alternatives

\subsection{Predicted Attainment of the Project Objectives of all Alternatives}

\subsubsection{Predicted Attainment of the Project Objective}

1. Generate a reasonable and legitimate amount of income for the Common School grant by harvesting approximately $2 \mathrm{MMBF}$ of timber.

2. Capture the value of dying and lower vigor trees before further decline.

3. Increase future revenue generating capacity by increasing timber production and over-all stand health through tree planting and pre-commercial thinning.

\subsubsection{Alternative A: No Harvest (No Action)}

Under this alternative, no trees would be harvested, thus no associated economic contribution to the School Trust would occur. The value of dying and low vigor trees would be lost to future decay. No improvements to the future revenue generating capacity of the affected area through tree planting or pre-commercial thinning would occur. This would have a direct effect upon the DNRC's obligation to provide the School Trusts with income.

\subsubsection{Alternative B: Harvest (Action)}

Under this alternative, approximately $2 \mathrm{MMBF}$ of timber would be harvested. This timber would be expected to generate an estimated $\$ 544,000.00$ to $\$ 662,000.00$ 
based comparable sales to the Common School trust grants. The value of dying and low vigor trees would be captured before future decline. Additionally, approximately 70 acres would be planted with tree seedlings and approximately 50 acres would be pre-commercially thinned to improve the future revenue generating capacity of the affected area.

\subsection{Predicted Effects on Relevant Resources of All Alternatives}

\subsubsection{Water Quality, Soils, Fisheries and Weeds}

\subsubsection{Water Quality}

\section{Alternative A: No Action Alternative: Direct, Indirect and Cumulative Effects}

Under the no action alternative effects to water quality would remain the same. Roads that do not meet Best Management Practice standards would continue to have drainage issues and erosion problems. The area supporting the Chamberlain Creek bridge would continue to erode and the risk of sediment delivery would increase.

\section{Alternative B: Action Alternative: Direct, Indirect and Cumulative Effects}

Under the action alternative, direct and indirect effects are expected to be minimal. The Blackfoot River is the only body of water located in the project area. There are only two proposed harvest units located near the Blackfoot River, units 36-a2 and 36-4. A Riparian Management Zone (RMZ) of approximately $80 \mathrm{Ft}$. would be implemented in both of these units. There would be no harvest within the first 50 $\mathrm{Ft}$. and $50 \%$ of the trees within the last $30 \mathrm{Ft}$. would be retained as this area is within the LMZ where no harvesting would occur. Also under a Memorandum of Understanding between Fish Wildlife and Parks and the DNRC, the DNRC will implement bull trout immediate actions, restricting any harvest or equipment operations within the streamside management zone ( Montana Department of Fish, Wildlife and Parks. 1994. Immediate Actions (for bull trout restoration). Lang Peterman, Administrator, Fisheries Division).

There are sections of road that do not meet Best Management Practices due to a lack of road drainage. These sections would be improved to meet BMP's, through installation of adequate drainage to reduce the risk of erosion. There are two culverts in the SE corner of section 36 that would require additional armoring to reduce erosion and increase stability at the inlet and outlet.

If it is used, the $250 \mathrm{ft}$. road segment adjacent to the Blackfoot River would be brought up to BMP standards and special mitigations would be required to ensure the risk of sediment delivery to the river would be minimal. If an alternate road segment were used for project activities in lieu of this one, improvements to this segment would not be necessary. If this segment were used, straw wattles or slash filter windrows would be installed for additional filtration, as well as rock surfacing to minimize rutting and erosion.

The existing Chamberlain Creek Big R bridge would be replaced with a larger, safer 
bridge, and the wooden bridge underneath would be removed. The installation and removal would occur during low water, prior to any harvest activities. Installation and associated road work would take up to 4 days. Disturbance associated with installation activities would produce short term increases in sediment delivery to the stream channel and in return, short term impacts to water quality. A larger, stable well armored structure that meets 100 year flood requirements would minimize the potential for long-term impacts to water quality. Specific sediment mitigations would be implemented as stated in the required 124 permit application. As a result, direct, indirect and cumulative impacts are expected to be minimal.

Pronone/Hexazinone would likely be applied on a site specific basis by ground application at low rates to improve establishment of conifers during reforestation. The size of the application circles is approximately $3 \mathrm{ft}$ diameter and the risk of erosion is low. This type of application has a positive benefit on seedling growth and lower risk of soil effects than mechanical site preparation treatments that remove the surface duff. Hexazinone may remain in the soil at low concentrations for up to three years. Hexazinone can be carried in runoff but, it is degraded rapidly in surface waters when light stimulates chemical reactions. However, Hexazinone will not be applied near any surface water or in areas of shallow groundwater.

Implementation of mitigation measures would result in low risk of direct, indirect and cumulative impacts to water quality.

\subsubsection{Soils}

\section{Alternative A: No Action Alternative: Direct, Indirect and Cumulative Effects}

Under the No Action Alternative there would be no direct, indirect or cumulative impacts to soil resources.

\section{Alternative B: Action Alternative: Direct and Indirect Effects}

Risk of direct and indirect impacts to soils is expected to be minimal with implementation of mitigation measures. The primary risks to long-term soil productivity are compaction and erosion of surface soils. During timber harvest, equipment operations on wet sites and sensitive soils can result in soil compaction, rutting, and erosion. Ground disturbing activities can also cause displacement of the nutrient rich litter and mineral surface soils. Excessive disturbance and displacement can result in a reduction of long-term soil productivity, and regeneration potential, as well as impacts to course woody debris distribution and nutrient cycling.

To minimize soil effects associated with the proposed activities, BMP's and slope restrictions would be implemented. There are areas with steep pitches greater than $45 \%$, which would require equipment restrictions zones to reduce the risk of soil damage.

Sharrott Rock Outcrop Complex 4-30\% slopes have a shallow surface layer and subsoil layer. These soils have lower production potential, which decreases as disturbance increases. The risk of erosion also increases on slopes greater than 
$40 \%$. Ground base operation would be limited to slopes of $40 \%$ or less on these soils (refer to soils map for specific location).

Tally Variant Sandy Loams 0-4\% have an increased risk to compaction and displacement. Skid trail planning would be designed to reduce the risk of erosion and compaction and minimize the amount of passes where possible.

Recommended mitigations for course woody debris would be implemented. Fallen logs and other course woody debris provide habitat for beneficial mycorrizal fungi, nutrient cycling and soil moisture storage (see Harvest Design Mitigation Measures for specifics).

\section{Harvest Design Mitigation Measures:}

- Cumulative impacts would be controlled by limiting the total soil disturbance area to $15 \%$ or less. This would be accomplished by using existing trails, skid trail planning and design and maintaining nutrient cycling by retaining woody debris and foliage in the harvest unit.

- Skidding should be limited to slopes of $45 \%$ or less, except on sensitive soils, where slope limitations should be $40 \%$ or less.

- Equipment operations should be limited to moderate slopes and periods when soils are dry, frozen or snow covered, to minimize disturbance that results in compaction, displacement, rutting and erosion.

- Surface drainage features should be installed on skid trails, landings and roads to minimize erosion.

- Localized sensitive soils, steep slopes and moist areas would be protected by equipment restriction zones.

- Harvest and slash disposal treatments would retain approximately 5- 15 tons/acre of large woody debris and a majority of fine slash well distributed over-all for nutrient cycling and long-term productivity. This may be accomplished by various methods, including in-woods processing or return slash skidding concurrent with harvest operations. Alternative methods for high slash concentrations would be approved by the forest officer and include the following options. 1) Lop and scatter slash, 2) excavator pile and redistribute slash as needed on slopes up to $45 \%, 3$ ) Dozer pile with slash blade on slopes up to $30 \%$, using caution to avoid excessive disturbance.

\section{Alternative B: Action Alternative: Cumulative Effects}

Cumulative effects could occur from repeated entries into a harvest area. Potential impacts to soils and risk of direct, indirect and cumulative effects would be minimized to acceptable levels by limiting total soil disturbance to $15 \%$ or less of 
the total area. This can be achieved by following the mitigation measures and implementation of Best Management Practices.

\subsubsection{Cold Water Fisheries}

\section{Alternative A: No Action Alternative: Direct, Indirect and Cumulative Effects}

Under the No Action Alternative, there are expected to be no direct, indirect and cumulative impacts to cold-water fisheries habitat. The Blackfoot River would still be listed as water quality impaired until it is reassessed in future TMDL analyses.

\section{Alternative B: Action Alternative: Direct, Indirect and Cumulative Effects}

The closest units located near the Blackfoot River are units 36a2 and 36-4 (refer to harvest unit map). There is a sufficient vegetative buffer between these units and the Blackfoot River. A Riparian Management Zone (RMZ) of approximately $80 \mathrm{Ft}$. would be implemented in both of these units. There would be no harvest within the first $50 \mathrm{Ft}$. and $50 \%$ of the trees within the last $30 \mathrm{Ft}$. would be retained as this area is within the LMZ where no harvesting would occur. Best Management Practices would also be implemented as well as restrictions listed under the conservation agreement between the DNRC and Fish Wildlife and Parks (refer chapter 3 Analysis Area).

Under the proposed action, habitat alteration is not expected to occur as a result of the proposed action and implementation of recommended buffers. Deferring harvest in the SMZ's would retain existing levels of stream shade and potential large woody debris recruitment, therefore, causing no detrimental effects to stream temperature and channel form and function.

Bridge installation is expected to result in short term increases in sediment, but decrease the risk of long-term sediment delivery. The bridge would be sized to adequately pass fish at all times of the year for all age classes. Sediment mitigations would be implemented as stated and agreed to in the 124 permit application. Installation would occur during low water to minimize any effects on life processes. As a result of mitigation measures, the risk of direct, indirect and cumulative effects are expected to be minimal.

\subsubsection{Noxious Weeds}

\section{Alternative A: No Action Alternative: Direct, Indirect and Cumulative Effects}

With the no-action alternative, noxious weeds, principally spotted knapweed would continue to spread along existing roads and onto drier vegetation types, mainly south slopes. 


\section{Alternative B: Action Alternative: Direct, Indirect and Cumulative Effects}

For the proposed timber harvest action alternative, ground disturbance would be low depending on season of use. The risk of weed introduction is expected to be low. Ground disturbing activities have the potential to introduce or spread noxious weeds in susceptible habitat types. The action alternative objective for weed management is to prevent new establishment of noxious weeds and control established populations along open roads. For this project an Integrated Weed Management (IWM) approach would be implemented that would include: prevention, revegetation and weed control measures for spot outbreaks, which are considered the most effective weed management treatments. Short-term effect would be to reduce existing noxious weed populations and increase native plants and seeded grasses. Where weeds are replaced with grasses, erosion would be reduced due to the improved plant cover. Localized herbicide applications and/or biological control agents would be used, primarily along disturbed roadside edges and spot treatments of small infestations. To protect water quality, herbicide would not be applied where runoff could enter surface waters or riparian features. Implementation of recommended mitigation measures would be expected to result in minimal direct, indirect and cumulative effects. See Integrated Weed Management Mitigations for mitigation specifics.

\section{Integrated Weed Management Mitigations}

To reduce current noxious weed infestations and limit the spread of weeds the following integrated weed management mitigation measures of prevention and control will be implemented.

- All road construction and harvest equipment would be cleaned of plant parts, mud and weed seed to prevent the introduction of noxious weeds. Equipment would be subject to inspection by forest officer prior to moving on site.

- Revegetate all newly disturbed soils on road cuts and fills promptly with site adapted grasses (including native species) to reduce weed encroachment and stabilize roads from erosion. For grass seeding to be effective it is important to complete seeding concurrent with road construction.

- Weed treatment measures include herbicide and/or biological applications along portions of project roads and accessible sites with a priority on spot outbreaks of noxious weeds and as designated by the Forest officer. Any restricted use herbicide treatments will be implemented by a certified applicator according to herbicide label directions in accordance with applicable laws and rules of Missoula and Powell County Weed District.

- DNRC would monitor the project area for two years. If new infestations of noxious weeds are noted, a weed management plan would be developed, implemented and coordinated with the lessee's efforts. 


\subsubsection{Human Environment}

\subsubsection{Recreation Opportunity and Quality}

Alternative A: No Action Alternative: Direct, Indirect and Cumulative Effects

A slight increase in recreational use of the project area would be expected to occur over time as human population increases. A low risk of direct, indirect and cumulative effects of the no action alternative degrading recreation opportunity and quality would be expected to occur.

\section{Alternative B: Action Alternative: Direct, Indirect and Cumulative Effects}

Recreation quality could be temporarily disrupted from a short-term increase in disturbance by project activity within the area during operational periods. Visibility within the affected stands would be increased. A low risk of direct, indirect and cumulative effects of the action alternative degrading recreation opportunity and quality would be expected to occur.

\subsubsection{Disruption, Noise, and Dust}

\section{Alternative A: No Action Alternative: Direct, Indirect and Cumulative Effects}

Highway traffic would continue to produce a relatively constant amount of noise. Dust would continue to be created by public motorists on gravel portions of county road (see Appendix A, Figure A-3 for a location description) during excessively dry periods. The Powell County road department would remain responsible for dust abatement if necessary. Creation of dust on private roads would remain insignificant. Disruption levels would remain low. There would be a low risk of direct, indirect and cumulative effects of the no action alternative causing excessive disruption, noise and dust.

\section{Alternative B: Action Alternative: Direct, Indirect and Cumulative Effects}

Increased traffic on county and private roads would be expected during periods of activity. Additionally, with increased use of roads, particularly log hauling; the risk to motorist safety could be increased. Mitigations would include posting safety signs on roads. Improvement work on the Chamberlain Creek bridge would temporarily block ingress and egress to two private residences. Communication between the DNRC forester overseeing the project and affected homeowners would also be expected to occur to coordinate bridgework.

Peace and solitude to private residents and potentially to recreationists along portions of private access roads would be temporarily disrupted, particularly if activities occurred during periods when most residents and recreationists were present (ie. primarily summer months). 
Noise associated with log truck traffic and heavy equipment operation would occur during periods of activity. If operations were to occur during excessively dry periods, dust could be produced, particularly during log hauling operations.

Operations occurring during the winter period would be expected to have minimal impacts to disruption, noise and dust. Non-operating periods for spring break-up conditions and bald eagle protection (4.3.4.1.1) would be implemented. This would help minimize impacts. In this area, spring break-up conditions usually occur from the middle of March through June. If log-hauling operations were to occur outside of winter conditions, affected home-owners would be contacted by the DNRC forester overseeing the project. Appropriate changes would be discussed and implemented as necessary.

Changes would include applying dust abatement to affected roads under appropriate conditions. The Powell county road department would maintain county roads. Another change would include coordinating log-hauling periods with affected homeowner activities to the extent practical.

With implementation of mitigation measures, a low risk of direct, indirect or cumulative effects of the action alternative causing excessive disruption, noise and dust would be expected to occur.

\subsubsection{Aesthetics}

\section{Desired Landscape Condition}

To determine guidelines for this project, two visual landscape management systems were used, the Visual Resource Management System (USDA 1977a, USDA 1977b, USDA 1980a, USDA 1980b), and the Scenery Management System (USDA 1995).

Through these methods, a desired Visual Quality Objective (VQO) was derived.

Retention:

"Activities may only repeat form, line, color, and texture which are frequently found in the characteristic landscape and should not be evident to casual forest visitors".

\section{Partial Retention:}

"Activities may repeat form, line, color, or texture which are found infrequently or not at all in the characteristic landscape, but remain visually subordinate to the visual strength of the characteristic landscape". 


\section{Modification:}

"Activities of vegetative and land form alteration must borrow from naturally established line, form, color, and texture so that their visual characteristics are those of natural occurrences within the surrounding area when viewed as middle ground or background. Activities may visually dominate the original characteristic landscape".

\section{Alternative A: No Action Alternative: Direct, Indirect and Cumulative Effects}

The risk of direct affects would be expected to be low. Over time, tree growth would be expected to fill in current, naturally occurring openings. Due to the long period of time involved, this affect would be expected to be low.

The risk of indirect affects would be expected to be insignificant. As timber stands become denser, stand health could decrease. This could increase the potential for high endemic insect infestations, resulting in contiguous portions of dead trees. Additionally, an increase of forest fuels would promote the potential for catastrophic wildfire events. Deforestation associated with insect damage and catastrophic wildfire would be expected to decrease aesthetics. Again, due to the long period of time involved and a wide range of variables, this risk would be low.

Past forest management activity on surrounding private lands, would contribute to the cumulative visual effects to project area landscape. The risk of cumulative affects would be expected to be low as disturbances from past forest management activities have mostly revegetated. A minimal amount of cumulative effects would be expected from the continued increase in vegetative growth due to the long period of time involved.

\section{Alternative B: Action Alternative: Direct and Indirect Effects}

Disturbances caused by improvement work to roads and the harvest of trees may have an impact on the visual resource. This impact is caused by contrasts created between the natural landscapes and managed landscapes. The extent to which the activities would affect the visual resource varies with how much they contrast in form, line, color, and texture. These differences are often subjective and are based on individual human perception. The Visual Quality Objective (VQO) determines the degree of acceptable change.

Methods described primarily as partial retention and modification would be used for timber management and road improvement work to achieve the desired VQO. Visual effects generated by timber management activities vary in duration and intensity according to the silvicultural treatment prescribed and the logging method used to achieve the silvicultural goals. Road improvement work can expose areas of light colored soils creating high color contrasts that can be seen for several miles. Over time, roads will revegetate and begin to blend with the natural landscapes. Slash also can contrast with the natural setting and can dominate viewing especially 
in the foreground. As slash cures, it changes to a reddish color that contrasts sharply to the natural greens, grays, and browns of a forest setting. This is generally a very short-term impact.

Due to the varying topography and small amount of area with low Visual Absorption Capacity (VAC) within the project area, much of the proposed action could remain "hidden" to the casual observer. Areas with the least amount of VAC would be most noticeable. These areas would generally consist of the steeper and higher elevation portions of proposed harvest units: $36-1,36-2,36-3$, and 36-a as well as the bench slopes facing NW in the lower elevation, NW portion of unit 36-1 (see Appendix A, Figure A-4. An experienced observer or someone who resides in the area would notice the changes to the other stands, mostly in the density of stands.

Where possible, much of the proposed cutting would be light to moderate in intensity. As many of the largest trees would be left, and a random, natural spacing would be used, it would be easier to decrease contrast in form, line, color, and texture between treated and untreated stands. Silvicultural treatments would borrow extensively from the natural grassy openings and only slightly affect the texture of the seen areas. Likewise, silvicultural treatments near areas of dense forest would borrow from the higher tree numbers and general stand characteristics (species, size, etc.). Along with silivicultural objectives, certain trees and clumps of trees would be selected to leave in these areas in an attempt to manage VAC.

Due to topography and distance, the proposed harvest area would be clearly visible from Montana Highway 200. Sloping topography faces the highway and the nearest proposed harvest area would be as close as approximately 500 feet away.

Recreational traffic (boating) is common along the Blackfoot river during the spring, summer and early fall. The proposed harvest units would be visible from the river, but to a lesser extent than the highway due to the low profile of the river level, the no-harvest corridor adjacent to the river (made up of the LMZ), and benchy terrain.

Several homesites, a public fishing access site and a DNRC office site exist within the seen area. The proposed harvest area would be visible from these sites.

The Russell Gates Park is located approximately 0.8 miles up-river from the project area. Topography within the proposed harvest area generally faces away from the park, but some visible effects of harvesting could be noticeable from the park.

\section{Alternative B: Action Alternative: Cumulative Effects}

Any change to the scenery in the area from these alternatives would be in addition to past timber harvests, road building, vegetation management (grazing, precommercial thinning, etc.) and fire activity within the project area. This analysis 
includes all past and present effects. Due to slash and the initial color contrasts of the slash and limited road improvement work, there is an expected short-term impact.

\subsubsection{Conservation Easement}

\section{Alternative A: No Action Alternative: Direct, Indirect and Cumulative Effects}

Current grazing practices would be expected to continue as directed under the conservation agreement. No proposals for land development or oil and gas leasing are known to exist at present time. The risk of direct, indirect or cumulative effects of the no action alternative not adhering to the conservation easement would be expected to be low.

\section{Alternative B: Action Alternative: Direct, Indirect and Cumulative Effects}

Prohibited and, or restricted activities, pertinent to the proposed action as stated in the conservation easement and the Rebbecca J. Dockter, Jan 7, 2003 Letter, would be adhered to. With this, the risk of direct, indirect and cumulative effects of the action alternative not adhering to the conservation easement would be expected to be low.

\subsubsection{Economics}

Costs, revenues, and estimates of return are estimates intended for relative comparison of alternatives. They are not intended to be used as absolute estimates of return.

\section{Alternative A: No Action Alternative: Direct, Indirect and Cumulative Effects}

No harvesting would take place and no additional revenue above current grazing lease receipts would be generated from the project area. No tree planting or precommercial thinning would take place. Additionally, no improvements would be made to improve the future timber revenue generating capacity of the affected area.

\section{Alternative B: Action Alternative: Direct, Indirect and Cumulative Effects}

\section{Forest Improvement (Tree planting and Pre-commercial thinning)}

Current estimates indicate the total tree planting costs assumed by DNRC would be approximately $\$ 21,000$ based on current average market costs for tree planting ( $\$ 300.00$ / acre X 70 acres). Potential pre-commercial thinning costs assumed by DNRC currently are estimated to be $\$ 5,500.00$ (based on current average market costs for pre-commercial thinning ( $\$ 110.00$ / acre X 50 acres). 


\section{Timber Harvest}

The estimated stumpage is based on comparable sales analysis. This method compares recent sales to find a market value for stumpage. These sales have very similar species, quality, average diameter, product mix, terrain, date of sale, distance from mills, road building and logging systems, term of sale or anything that could affect a buyers willingness to pay for stumpage. The estimated stumpage price $(\$ / M B F)$ for the lower end of the range equals approximately $\$ 272.00$ (Sweeney Creek Timber Sale) and conversely $\$ 331.00$ (Evans Lake Timber Sale) at the upper end of the range. These two comparable timber sales were sold based on tons. Seven tons per MBF was used as a conversion factor.

Total revenue from stumpage receipts for the Common Schools trust grant would yield between $\$ 544,000.00$ and $\$ 662,000.00$ based on the above comparable sales.

\subsubsection{Cultural and Historic Resources}

\section{Alternative A: No Action Alternative: Direct, Indirect and Cumulative Effects}

Over time, evidence of potential cultural and historic resources would be expected to diminish as a result of natural processes. Potential effects associated with wildfire and wildfire suppression, livestock grazing, etc. would be expected to continue. The risk of affects associated with recreational use would be expected to increase over time. The risk of direct, indirect and cumulative effects of the no action alternative on cultural and historic resources would be expected to be low.

\section{Alternative B: Action Alternative: Direct, Indirect and Cumulative Effects}

In order to help mitigate potential effects from harvest activities if a cultural resource is discovered during timber sale activities, a clause has been inserted in to all timber sale contracts, which reads as follows:

"If a cultural resource is discovered, the Purchaser shall immediately suspend all operations in the vicinity of the cultural resource and notify the Forest Officer. Operations may only resume if authorized by the Forest Officer. Cultural resources identified and protected elsewhere in this contract are exempted from this clause."

The risk of direct, indirect and cumulative effects of the action alternative on cultural and historic resources would be expected to be low. 


\subsubsection{Vegetation}

\subsubsection{Natural Role of Wildfire}

\section{Alternative A: No Action Alternative: Direct, Indirect and Cumulative Effects}

Wildfires would continue to be suppressed. As a result, natural, forest succession would be expected to continue without the presence of frequent, low-intensity fire. The expected result would be an increase in the amount of fuels over time and could eventually result in stand conditions at high risk to catastrophic, stand replacement wildfire. The increase in this type of stand condition would be expected to decrease the effectiveness of common wildfire suppression tactics. The direct, indirect and cumulative effects of the no action alternative to the natural role of wildfire would be expected to increase over time.

\section{Alternative B: Action Alternative: Direct, Indirect and Cumulative Effects}

Proposed harvest treatments would be expected to help decrease the risks of direct, indirect and cumulative effects. These harvest treatments would be expected to somewhat emulate the effects of a frequent, low-severity wildfire regime. Harvest treatments would be expected to reduce susceptibility to catastrophic, stand replacement wildfire. Additionally, proposed harvest would move the treated stands closer to a condition which would have been expected to occur under, a natural condition with the natural role of wildfire. Slash that is not disposed of would be available as fuel for wildfire. Slash presents the highest risk during the first two years following stand treatment prior to the breakdown of the fine materials. Proposed slash treatments would minimize this risk. Thus, a low risk of direct, indirect, and cumulative effects to the natural role of wildfire as a result of the action alternative would be expected to occur.

\subsubsection{Forest Fragmentation}

\section{Alternative A: No Action Alternative: Direct, Indirect and Cumulative Effects}

Forests within the project area would evolve under natural forest succession, except that wildfires would continue to be suppressed. Many natural openings would close as the encroachment of Douglas-fir and young ponderosa pine trees increase.

Species composition would gradually favor those associated with denser, multistoried stands. The risk of stand replacing fires or insect epidemics would increase over time. The extent and timing of future logging on private timberlands is currently unknown. Additional logging of these lands, however, is expected to continue unless future changes in ownership affect management practices.

Areas of denser cover would remain, providing for wildlife habitat cover and some travel corridors. Connectivity of wildlife habitat could increase over time provided, no stand replacing events occur. Over-all, under the no action alternative, there would be low risk of direct, indirect or cumulative effects to Forest Fragmentation. 


\section{Alternative B: Action Alternative: Direct, Indirect and Cumulative Effects}

Historically, forested areas that were subjected to the types of fire regimes that were present in the Headquarters Timber Sale project area likely had a high degree of fragmentation. The frequent low-intensity underburns and mosaics of forest cover created by fires of varying shapes and intensities prevented the development of large areas of closed canopy forest. As humans have suppressed wildfires, these stands have become overstocked, and as a result, have begun to provide a small amount of interior forest habitat. It is the intent of the proposed action alternative to remove those trees, which have encroached upon timber stands within the project area. By removing these trees, DNRC hopes to emulate more open stand conditions, which existed within the project area historically.

It is likely that there were portions of stands within the project area, which did not burn as frequently as those stands described above. While these areas may not have been of sufficient size and/or density to provide true interior forest habitat, they were more dense than the open, park-like ponderosa pine stands found on the majority of the area. Some of the areas that would be treated, would retain more of the shade-tollerant Douglas-fir, as well as some Western larch, which would retain more of the moister, cooler qualities of stands which would have experienced lower fire intensities.

Over-all, by attempting to somewhat emulate the suspected natural, historic role of wildfire the risks of direct and indirect affects would be expected to be low. A slight increase in cumulative effects would be expected to occur.

\subsubsection{Leave Trees}

\section{Alternative A: No Action Alternative: Direct, Indirect and Cumulative Effects}

No harvest would occur, thus there would be no direct, indirect or cumulative effects as a result of improper leave tree selection.

\section{Alternative B: Action Alternative: Direct, Indirect and Cumulative Effects}

Tree species known to have wind-firm root systems would be favored to leave. Additionally, individual trees displaying over-all, healthy visual characteristics would be favored to leave. Relatively flat or gently sloping topography exists across much of the project area and would be expected to have a low to moderate exposure to high winds. The risk of direct, indirect and cumulative effects would be expected to be low to moderate. 


\subsubsection{Natural Tree Regeneration}

\section{Alternative A: No Action Alternative: Direct, Indirect and Cumulative Effects}

Timber stands would be expected to continue the process of forest succession in the absence of wildfire. This would increasingly discourage the establishment of seral species such as ponderosa pine and western larch over time. These two species require the sunlight offered by a relatively open tree canopy to regenerate naturally. Douglas-fir would continue to regenerate. No apparent risk of direct, indirect or cumulative impacts would be expected to occur as a result of harvest practices, as no harvest would occur.

\section{Alternative B: Action Alternative: Direct, Indirect and Cumulative Effects}

For the most part, even-aged harvest treatments would not be proposed under the action alternative. Primarily uneven-aged practices would be implemented. These treatments would however, include a semblance of even-aged management. In these situations, the basal area would be reduced to a level that would permit natural regeneration of Ponderosa pine in areas within treated stands rather than the entire stand. Harvest treatments would leave an average of between approximately 30 40 square feet of basal area per acre.

Areas with low stocking levels of regeneration would be planted with tree seedlings of representative species. This includes some areas within proposed harvest units. The risk of direct, indirect and cumulative affects would be expected to be low.

\subsubsection{Wildlife}

\subsubsection{Threatened and Endangered Species}

\subsection{Bald Eagle}

\section{Alternative A: No Action Alternative: Direct and Indirect Effects}

Under the no action alternative, there would be little change from existing conditions, with the exception of gradual vegetative change associated with forest succession. Thus, there would be minimal risk of direct and indirect effects to bald eagles as a result of the no action alternative.

\section{Alternative A: No Action Alternative: Cumulative Effects}

Within a 3-mile radius surrounding the project area, under the no action alternative, there would be little change from existing conditions. Thus, there would be minimal risk of cumulative effects to bald eagles as a result of the no action alternative. 


\section{Alternative B: Action Alternative: Direct and Indirect Effects}

Because the proposed action would include winter harvest, there would be potential for disturbance to bald eagles prior to the breeding season (i.e., beginning February 1). The proposed haul route would be between $210 \mathrm{ft}$ and 0.25 mile of the 5 known nests within the Sperry Grade bald eagle territory. As of the 2004 breeding season, the occupied nest (Appendix A, figure A-8) is approximately 0.25 mile from the proposed haul road.

Under a scenario where the Bald Eagle Management Plan and ARM 36.11.429 are implemented, to minimize potential disturbance during the breeding season, mechanized activity (i.e., hauling, timber falling, use of automobiles for administrative use, chainsaws, etc.) would be restricted within 0.25 mile of the active nest (i.e., the Nest Site Area; ARM 36.11 .403 (7)) between February 1 and August 15 (pursuant to ARM 36.11.429). Additionally, because the nest building/courtship behavior time frame (February 1 to April 15) is the most sensitive period to human activity (Montana Bald Eagle Working Group 1994), mechanized activity would be restricted in both the nest site ( 0.25 mile radius) and primary use (0.5 mile radius) areas (pursuant to ARM 36.11.429 and Montana Bald Eagle Management Plan). Should the Purchaser desire an alternate haul route that would enable them to haul through the month of February, an alternate route is available south of the affected parcel, however it would be the Purchaser's responsibility to secure the access. The alternate route would be located $>0.5$ mile from all known bald eagle nests and would have minimal risk for direct and indirect effects to bald eagles. The silvicultural prescription for the proposed action would retain forest structure conducive to bald eagle utilization of the project area. Thus, through implementation of temporal avoidance measures, the silvicultural prescription for bald eagle habitat features, and implementation of measures from the Bald Eagle Management Plan and DNRC's Forest Management Rules, the proposed action would likely have low risk of direct and indirect effects to bald eagles

On 1 June 2004, a field visit was made to the area by Mike McGrath (DNRC Wildlife Biologist), Kristi DuBois (MT DFWP, Native Species Coordinator and Montana Bald Eagle Coordinator), Jim Sparks (BLM Wildlife Biologist and member of Montana Bald Eagle Working Group), Mike Thompson (MT DFWP Wildlife Biologist), and Dave Marsh and Craig Nelson (DNRC Foresters). The purpose of the field visit was to ascertain the influence the proposed action may have on nesting bald eagles. A GPS location of the 2004 active nest was obtained during the field visit, and attempts to observe the nest from the haul road were unsuccessful due to the vegetative screening between the two features (Appendix A, Figure A-8). Due to the distance (approximately 0.25 mile) and, more importantly, the vegetative screening between the proposed haul road and the 2004 nest, all parties were of the opinion that mechanized activity (i.e., motorized administrative use and log trucks) along the proposed route would present minimal disturbance to nesting or the pair-bond formation on this 
territory (Sparks' and DuBois' field notes and recommendations on file with SWLO Wildlife Biologist). Thus, it was the consensus of the group that deviation from the Montana Bald Eagle Management Plan (and thus ARM 36.11 .429 1.c.i) regarding mechanized activities within the Nest Site Area was appropriate, provided certain mitigations would be implemented. Recommended mitigations to minimize the risk of disturbance to bald eagles include:

- Beginning timber harvest in the units closest to the known nest sites during the non-breeding season (August 16 - January 31), and working away from the nests;

- All timber would be hauled along the road designated in red (Appendix A, figure A-8) rather than hauling timber on the road in section 25 (T15N R14W, a road that would take mechanized activity closer to the nests);

- Roads used to access the proposed harvest for administrative use would be limited to either the hauling route (Appendix A, figure A-8), or the road accessing the SE $1 / 4$ of the parcel;

- Nest activities would be monitored for adverse effects from hauling activities; and During the time that the proposed action would occur, should the bald eagle pair select a nest site closer to the proposed hauling route where distance and visual screening would not mitigate the potential effects of mechanized activity, then mechanized activity within the Nest Site Area would be restricted between February 1 and August 15.

Thus, in order to deviate from the Bald Eagle Management Plan and ARM $36.11 .429(1)(c)(i)$, the aforementioned mitigations would be implemented under the proposed action in efforts to reduce the risk of disturbing bald eagles during the breeding season. Provided the mitigations are properly implemented, there would be low risk of direct and indirect effects to bald eagles as a result of the proposed action, with deviations from the Bald Eagle Management Plan and DNRC's Forest Management Rules.

\section{Alternative B: Action Alternative: Cumulative Effects}

Within the 3-mile radius cumulative effects analysis area, the proposed actions implementation of temporal avoidance measures, along with DFWP's Conservation Easement along the Blackfoot River in the project area and sections 2 and 10, would retain habitat features along foraging areas for bald eagles. Additionally, with the occurrence of Highway 200 and the Russell Gates Campground within the Nest Site Area of several alternate nests within the Sperry Grade territory (including the 2004 nest), and the fact that the territory was established after the aforementioned disturbance factors, occupants of this territory have demonstrated tolerance to varying levels of mechanized and recreational disturbance within the Nest Site Area. As a result, there would be low risk of cumulative effects to bald eagles as a result of the proposed action. 


\subsection{Grizzly Bear}

\section{Alternative A: No Action Alternative: Direct and Indirect Effects}

Under the no action alternative, vegetative cover would remain unchanged, except for the gradual change that comes with forest succession and continued fire suppression. As a result, Douglas-fir would continue to grow and eventually replace ponderosa pine as the predominant tree species on the affected parcel. This would continue to provide grizzly bears with vegetative screening along riparian areas and roads. Roads within the parcel would continue to be used for administrative use only, and public motorized access would continue to be prohibited. Thus, there would be minimal risk of direct and indirect effects to grizzly bears as a result of the no action alternative.

\section{Alternative A: No Action Alternative: Cumulative Effects}

With no action, grizzly bear habitat, as well as habitat for many other wildlife species in the Blackfoot Valley may be affected by the disposition of certain Plum Creek Timber lands. Currently, Plum Creek would dispose of approximately 42,000 acres within the valley that are east of Highway 83, to The Nature Conservancy, who would have an option on an additional 44,000 acres. These lands would then be transferred to the USFS, BLM, and other agencies. Within the cumulative effects analysis area, approximately 50,469 acres could be affected by this land sale. This transfer of lands could result in greater habitat protection through reduction in open road densities and management with grizzly bear consideration's. In addition to the land transfer, bears within the area could be affected by the Lost Bear, Clearwater River, Sour Fish, and Haywire Wallace timber sales on school trust land. However, each of these DNRC projects have worked to either maintain or reduce open road densities within their respective project areas in an effort to minimize effects on grizzly bears. As a result, there would be low risk of cumulative effects to grizzly bears as a result of the no action alternative.

\section{Alternative B: Action Alternative: Direct and Indirect Effects}

The proposed action would begin the restoration of the ponderosa pine plant community within the affected parcel through the selective harvest of primarily Douglas-fir on approximately 331 acres, while favoring ponderosa pine as the retention trees and maintaining the uneven aged, multi-storied structure. The proposed action would not increase open road densities. Through adherence to the conservation license previously granted to Montana DFWP, vegetative screening along the Blackfoot River would be maintained. Additionally, the proposed harvest, through implementation of the proposed silvicultural prescription, would still retain visual screening cover in the uplands through retention of all age classes of healthy ponderosa pine. However, some of the current upland screening cover would be reduced through harvest of Douglas-fir. Thus, there would be changes in vegetative cover that could produce low risks of 
direct and indirect effects to grizzly bears within the project area. However, due to the restricted public access, and the affected area being part of an archery-only hunting unit, the effects to grizzly bears as a result of the proposed action may be minimized.

\section{Alternative B: Action Alternative: Cumulative Effects}

While the proposed action would result in temporary reductions in screening cover in portion of the project area, at the scale of the cumulative effects analysis area, grizzly bears would face similar effects as described under the No Action Alternative. The proposed action would not: a) construct additional road, b) result in increased open road densities, or c) reduce screening cover along open roads and riparian areas. As a result, there would be low risk of cumulative effects to grizzly bears as a result of the proposed action.

\subsection{Gray Wolf}

\section{Alternative A: No Action Alternative: Direct and Indirect Effects}

Under the no action alternative, vegetative cover would remain unchanged, except for the gradual change associated with forest succession and continued fire suppression. As a result, Douglas-fir would continue to grow and eventually replace ponderosa pine as the dominant tree species on the affected parcel. Roads within the parcel would continue to be used for administrative use only, and public motorized access would continue to be prohibited. Thus, there would be minimal risk of direct and indirect effects to wolves as a result of the no action alternative.

\section{Alternative A: No Action Alternative: Cumulative Effects}

Cumulative effects for gray wolves under the no action alternative would be similar to those for grizzly bears. The current land sale of Plum Creek lands to The Nature Conservancy, and those land's eventual disposition to public agencies, has the potential to greatly impact wolves through public motorized access. Currently Plum Creek permits public non-motorized access to their lands for recreational activities such as hunting. How these lands are eventually dispensed, and how those owners deal with public motorized access may affect wolves in the future. If these lands continue to be managed with public nonmotorized access, there would be no change to wolf vulnerability under the no action alternative.

\section{Alternative B: Action Alternative: Direct and Indirect Effects}

Because the proposed action would not construct additional road, or increase open road density, wolves may be affected primarily through associated vegetation changes that might alter big game densities. Under current canopy conditions, snow-intercept cover is virtually non-existent because the project area 
is primarily a ponderosa pine site that has been invaded by Douglas-fir. Thus, the snow-intercept cover is scattered and clumpy and would not likely accommodate very many deer or elk. As a result of the proposed action, much of this scattered and clumpy snow-intercept cover would be removed. However, this action would not likely affect big game use of the project area, and thus would have low risk of direct and indirect effects to gray wolves.

\section{Alternative B: Action Alternative: Cumulative Effects}

The cumulative effects analysis area encompasses the Blanchard wolf pack, and likely sees occasional use by the Potomac pack. As such, the affected parcel may see occasional use by wolves. However, wolves are more likely to be affected by actions occurring in Blanchard Creek and on the Blackfoot-Clearwater Game Range. Montana DFWP recently purchased a conservation easement from DNRC for School Trust lands within the Game Range. This easement purchased DNRC's development rights for those affected parcels, which would guarantee reduced human development, reduced effects to wintering big game, and thus, reduced effects to gray wolves. As a result, the proposed action would reduce snow-intercept cover for big game on the project area, but when examined at the cumulative effects scale, there would be low risk of cumulative effects to gray wolves as a result of the proposed action.

\subsubsection{Sensitive Species}

\subsection{Pileated Woodpecker}

\section{Alternative A: No Action Alternative: Direct and Indirect Effects}

The no action alternative would continue forest management as it currently exists, with potential for future small timber permits or timber sales that would each be subject to environmental review. Gradual vegetative change would occur through normal forest succession, whereby Douglas-fir may eventually out-compete ponderosa pine in the affected parcel and provide for pileated woodpecker nesting and roosting sites in the form of larger diameter $(>15$ inch $\mathrm{dbh}$ ) ponderosa pine snags. However, perpetuation of Douglas-fir within the affected parcel would increase the likelihood of stand replacement fire due to the presence of ladder fuels. Thus, the no action alternative would likely have low risk of direct and indirect effects to pileated woodpeckers.

\section{Alternative A: No Action Alternative: Cumulative Effects}

Within a 1-mile radius of the affected parcel, vegetation is comprised of natural grasslands as well as extensive areas of forestland harvested in the 1990's on private industrial land that has not yet returned to suitable conditions for pileated woodpecker nesting and roosting. The no action alternative would benefit pileated woodpeckers within the cumulative effects area through the continuation of suitable habitat. 


\section{Alternative B: Action Alternative: Direct and Indirect Effects}

The proposed action would harvest primarily Douglas-fir, and some ponderosa pine, on approximately 289 acres of the 463 acres of suitable pileated woodpecker habitat within the affected parcel. In doing so, many of the structural characteristics (i.e., uneven-aged stand, larger diameter ponderosa pine and western larch) would be retained that appeal to this species. In addition, at least 1 snag and 1 snag recruit that are $\geq 21$ inches dbh would be retained per acre for nesting and roosting habitat. However, the proposed harvest may also delay the senescence of ponderosa pine within the parcel through removal of Douglas-fir that would eventually out-compete the pine for resources and thusly create more abundant nesting and roosting habitat (i.e., snags). Essentially, the risk of direct and indirect effects to pileated woodpeckers as a result of the proposed action would be low, and would likely enhance habitat for this species in both the short- and long-term.

\section{Alternative B: Action Alternative: Cumulative Effects}

Within the cumulative effects analysis area (a 1-mile radius surrounding the project area), the proposed action would likely restore a portion of the habitat within the analysis area to the more natural ponderosa pine stand conditions. While the proposed action would reduce canopy closure within the affected parcel, pileated woodpecker habitat would likely not be further degraded due to the retention of uneven aged ponderosa pine stands, with the presence of larger diameter ponderosa pine and western larch. Thus, there would likely be low risk of cumulative effects to pileated woodpeckers as a result of the proposed action.

\subsection{Black-backed Woodpecker}

\section{Alternative A: No Action Alternative: Direct and Indirect Effects}

Under the no action alternative, the risk of stand replacement fire occurring on the affected parcel would increase with the gradual increase in ladder fuels (i.e., seedling and sapling Douglas-fir trees). As a result, there would be the potential for creation of black-backed woodpecker habitat over time through the no action alternative.

\section{Alternative A: No Action Alternative: Cumulative Effects}

As discussed under direct and indirect effects, there would be the potential for creation of black-backed woodpecker habitat through increased risk of stand replacement fire. Should such a fire occur, it would add to the growing acreage of recently burned acres within the Blackfoot Valley, including the combined 23,456 acres burned by the Boles Meadow, Dirty Ike, Mineral-Primm, and Stuart Peak fires in 2003. Thus, the no action alternative could potentially benefit black-backed woodpeckers in the long-term. However, with the Montana DNRC 
Clearwater Initial Attack Unit located within the same affected parcel, the likelihood of such a fire occurring may be low.

\section{Alternative B: Action Alternative: Direct and Indirect Effects}

The proposed action would harvest primarily Douglas-fir and some ponderosa pine on approximately 331 acres within the affected parcel. The purpose for such action would be to restore the parcel to a semblance of the open ponderosa pine forest of the historic past, and also to reduce the likelihood of stand replacing fire. As a result, the proposed action could reduce the likelihood that the affected parcel could become temporary black-backed woodpecker habitat in the long-term ( 20 to 40 years). Thus, there would be low risk of direct and indirect effects to black-backed woodpeckers as a result of the proposed action alternative.

\section{Alternative B: Action Alternative: Cumulative Effects}

Within 28 miles west of the project area, the fires of 2003 burned approximately 23,456 acres on four fires: Dirty Ike, Boles Meadow, Mineral-Primm, and Stuart Peak. The proposed action would reduce the likelihood of a stand replacement fire occurring on this 640 acre parcel, through reduction in Douglas-fir density, and the presence of ladder fuels. However, the DNRC Clearwater Initial Attack Unit is located on the same parcel, albeit on the north side of the Blackfoot River. As a result, the proximity of the Initial Attack unit would also reduce the likelihood of stand replacement fire occurring on the affected parcel. Because of the abundance of black-backed woodpecker habitat within the cumulative effects analysis area, and the proximity of the Initial Attack unit, their would be low risk of cumulative effects to black-backed woodpeckers as a result of the proposed action.

\subsection{Flammulated Owl}

\section{Alternative A: No Action Alternative: Direct and Indirect Effects}

Under the no action alternative, the affected parcel would continue to be suitable flammulated owl habitat for approximately 30 years. After approximately 30 years, the majority of the Douglas-fir will likely have grown up into the overstory for almost continuous canopy closure on the parcel. Because flammulated owls prefer more open stands (i.e., $30-50 \%$ canopy closure), the suitability of this parcel for this species would likely be reduced over time. Thus, there would be low to moderate risks of direct and indirect effects for flammulated owls that may occur on the affected parcel as a result of the no action alternative. 


\section{Alternative A: No Action Alternative: Cumulative Effects}

Because flammulated owl home ranges are typically $<50$ acres (McCallum 1994), the cumulative effects analysis area will also be the project area. Similar to the direct and indirect effects analysis, over time, and with a lack of fire in the parcel, the suitability of the parcel for flammulated owls would decrease due to increasing canopy closure from Douglas-fir. Such conditions would occur within those acres of the affected parcel covered by the Fish, Wildlife \& Parks Conservation Easement, which prohibits timber harvesting. Thus, the no action alternative would have low to moderate risk of additive cumulative effects to flammulated owls within the affected parcel.

\section{Alternative B: Action Alternative: Direct and Indirect Effects}

The proposed action would harvest Douglas-fir and some ponderosa pine, in an uneven aged selection method, on approximately 331 acres of the affected parcel. All of those acres are within approximately 627 acres of suitable flammulated owl habitat. Through the uneven-aged selection, the proposed action would ensure multi-storied structure, relatively open canopy closure, and patches of regeneration throughout the parcel, which would likely benefit this species. Additionally, such action would likely reduce the risk of stand replacement fire, which would destroy suitable flammulated owl habitat, within the project area. Thus, there would be minimal risk of direct or indirect effects to flammulated owls as a result of the proposed action.

\section{Alternative B: Action Alternative: Cumulative Effects}

Within the cumulative effects/project area, the proposed action would likely benefit flammulated owls through maintaining habitat suitability for this species. The Conservation Easement DNRC entered into with FWP prohibits timber harvesting within a restriction zone adjacent to the Blackfoot River. As a result, the overstory on those acres will eventually be closed, and comprised of ponderosa pine and Douglas-fir, and would have lower value as habitat for flammulated owls. As discussed in the direct and indirect effects analysis, through the proposed action's uneven aged selection, multi-storied structure, relatively open canopy closure, and patches of regeneration would be ensured throughout the parcel, which would likely benefit this species. Thus, there would be low risk of cumulative effects to flammulated owls as a result of the proposed action.

\subsection{Fisher}

\section{Alternative A: No Action Alternative: Direct and Indirect Effects}

No changes from current conditions would be expected under the no action alternative. 


\section{Alternative A: No Action Alternative: Cumulative Effects}

No changes from current conditions would be expected under the no action alternative.

\section{Alternative B: Action Alternative: Direct and Indirect Effects}

Under the proposed action, approximately 34 acres out of 123 acres of fisher preferred habitat types within the project area would experience some level of timber harvest, most likely an uneven aged harvest focused primarily on Douglas-fir. Approximately 17 of the 34 acres are located along a ridge, which may not receive use by fisher due to its topographic location. The proposed action would likely result in $30 \%$ to $50 \%$ canopy closure on the affected acres, which may not be conducive to use of the area by fisher. However, current canopy closure estimates are $<80 \%$ throughout the parcel. Thus, while the proposed action would reduce canopy closure, it would not likely change the current overall suitability of the parcel for fishers. Therefore, there would likely be low risk of direct and indirect effects to fisher as a result of the proposed action.

\section{Alternative B: Action Alternative: Cumulative Effects}

The landscape within a 1-mile radius of the project area is roughly $60 \%$ grassland and $40 \%$ forested. Of the forested acres, all 668 of the private industrial acres have been harvested and are currently in early successional stages, and thus, may not currently be suitable for fishers. The proposed action would harvest timber using an uneven aged silvicultural prescription that would retain the multi-storied stand structure that fishers prefer. However, the prescription would also reduce canopy closure to approximately $30 \%$ to $50 \%$, which may not be desirable for use by fishers. Although the proposed action may temporarily reduce the suitability of the landscape for fishers, much of the desired forest structure would be present and adjacent to a riparian corridor along the Blackfoot River that has been guaranteed in perpetuity through a conservation easement with the Montana DFWP. Thus, the proposed action may temporarily have a low risk of cumulative effects for fisher, however those effects may be minimized over time as the vegetation responds to timber harvest and new owners for the private industrial land exert their influence on the landscape.

\subsection{Harlequin Duck}

\section{Alternative A: No Action Alternative: Direct and Indirect Effects}

No changes from current conditions would be expected under the no action alternative. 


\section{Alternative A: No Action Alternative: Cumulative Effects}

No changes from current conditions would be expected under the no action alternative.

\section{Alternative B: Action Alternative: Direct and Indirect Effects}

The proposed action would include winter operations and likely other periods during the non-breeding season for harlequin ducks. Additionally, harvest operations would not occur within 180 feet (as measured with GIS) of the Blackfoot River, and the topography of the proposed units closest to the river is relatively flat and well vegetated with grasses, duff, and shrubs. Given these conditions, there would be: (1) low risk of water quality degradation by the proposed action; (2) retention of vegetative cover along the river for potential nesting habitat; and (3) operations would most likely be outside of the breeding season for Harlequin Ducks. As a result, there would be minimal risk of direct and indirect effects to this species as a result of the proposed action.

\section{Alternative B: Action Alternative: Cumulative Effects}

Given the analysis of direct and indirect effects for this species, and the FWP Conservation Easement that would retain vegetation and prohibit equipment use within the Easement's restriction zone in perpetuity, there would be minimal risk of cumulative effects for Harlequin Ducks as a result of the proposed action.

\subsubsection{Big Game}

\subsection{Moose}

\section{Alternative A: No Action Alternative: Direct and Indirect Effects}

No changes from current conditions would be expected under the no-action alternative.

\section{Alternative A: No Action Alternative: Cumulative Effects}

No changes from current conditions would be expected under the no-action alternative.

\section{Alternative B: Action Alternative: Direct and Indirect Effects}

The proposed action would reduce the amount of snow-intercept cover available within the project area through implementation of the uneven aged silvicultural prescription. However, riparian habitats, which are preferred by moose, would not be entered in accordance with existing SMZ law and the FWP Conservation Easement. Thus, riparian vegetation and hiding cover would be retained within 
at least 180 feet of the Blackfoot River, maintaining a travel corridor, however, hiding cover would be reduced within the harvest units. Despite the reductions in hiding cover within the approximately 331 acres proposed for harvesting, the area is part of an Archery-Equipment Only hunting area, and moose would likely only have a slightly higher level of vulnerability for approximately 20 years until forest vegetation replaces the lost hiding cover within the proposed harvest units. Thus, there would be low risk of direct and indirect effects to moose as a result of the proposed action alternative.

\section{Alternative B: Action Alternative: Cumulative Effects}

While the proposed action would harvest timber, it likely would not create additional foraging habitat to add to the approximately 33,397 acres of seedtree/shelterwood harvest, clearcuts, and grassland within the analysis area. However, it would not harvest within riparian habitats and would maintain a travel corridor along the Blackfoot River. Thus, there would be low risk of cumulative effects to moose as a result of the proposed action alternative.

\subsection{Elk, White-tailed, and Mule Deer}

\section{Alternative A: No Action Alternative: Direct and Indirect Effects}

No changes from current conditions would be expected under the no action alternative.

\section{Alternative A: No Action Alternative: Cumulative Effects}

No changes from current conditions would be expected under the no action alternative.

\section{Alternative B: Action Alternative: Direct and Indirect Effects}

Through the proposed harvesting of 331 acres within the project area, there would by reductions in snow-intercept cover from approximately 143 acres to approximately 54 acres, and security cover from approximately 97 acres to approximately 43 acres. Due to concerns regarding existing cabin sites and the Clearwater Unit office, DNRC has designated that only archery equipment can be used for hunting big game on the parcel. As a result, due to the limited range of archery equipment, the proposed reduction in security cover may have minimal effects on elk and deer within the parcel. Through the likely reduction in snow-intercept cover, deer and elk would expend more energy during winter while on the affected parcel. During an especially hard winter, reductions in snow-intercept cover as a result of the proposed action may contribute the deaths of some deer and elk. Thus, there would likely be low risk of direct and indirect effects for elk, white-tailed, and mule deer as a result of the proposed action. 


\section{Alternative B: Action Alternative: Cumulative Effects}

The proposed action would reduce security cover within the analysis area from approximately 9,259 acres $(39.44 \%)$ to 9,255 acres $(39.42 \%)$. In conjunction with the Little Fish Creek and Lost Bear Timber Sales, there would be cumulative reductions in elk security cover, however, such reductions are likely to have low risk of cumulative negative effects for deer and elk within the analysis area. 


\subsection{List of Individuals Associated with the Project}

Preparers:

Dave Marsh

Mt. DNRC

CLW Project Leader

John Hansen

Mt. DNRC

CLW Former Project Leader (1999)

Rob Lionberger

Mt. DNRC

Mt. DNRC

CLW

Former Project Leader (2000-2001)

Craig Nelson

Mt. DNRC

CLW

Decision Maker

Mike McGrath

SWLO

Wildlife Biologist

Rose Leach

Mt. DNRC

Former Wildlife Biologist (1999)

Renee Myers

Patrick Rennie

Stephen J. Wallace

Mt. DNRC

SWLO

Hydrologist / Soil Scientist

Mt. DNRC

SWLO

Mt. DNRC

Lands

CLW

Archaeologist

Unit Manager

CLW

Clearwater Unit, Greenough, MT

SWLO

Southwestern Land Office, Missoula, MT

Lands

Land Management Section, Helena, MT 



\subsection{References}

\section{Literature Cited}

Arno, S.F., J.H. Scott, and M.G. Hartwell. 1995. Age-class structure of old growth ponderosa pine/Douglas-fir stands and its relationship to fire history. USDA Forest Service Research Paper. INT-RP-481. .25pp.

Bellrose, F. C. 1980. Ducks, geese and swans of North America. Stackpole Books, USA.

Buehler, D. A. 2000. Bald eagle (Haliaeetus leucocephalus). Pages 1-40 in The Academy of Natural Sciences; The American Ornithologists' Union, Philadelphia, Pennsylvania.

Bull, E. L., S. R. Peterson, and J. W. Thomas. 1986. Resource partitioning among woodpeckers in northeastern Oregon. E. L. Bull, S. R. Peterson, and J. W. Thomas (Resource partitioning among woodpeckers in northeastern Oregon. U. S. Department of Agriculture, Forest Service, Pacific Northwest Research Station, Portland, Oregon. Research Note PNW-444.

Clem, M. K. 1977. Food habits, weight changes and habitat use of fisher Martes pennanti during winter. M. S. Thesis, University of Guelph, Guelph, Ontario.

Coulter, M. W. 1966. Ecology and management of fishers in Maine. Dissertation, Syracuse University, Syracuse, New York.

Hewitt, D. G. and C. T. Robbins. 1996. Estimating grizzly bear food habits from fecal analysis. Wildlife Society Bulletin 24:547-550.

Conversation with George Mathieus from the Department of Environmental Quality in Helena on the subject of TMDL's).

Fischer, W.C., and A.F. Bradley. 1987. Fire ecology of western Montana forest habitat types U.S. For. Serv. Gen. Tech. Rep. INT-223. 95pp.

Ffolliott, Peter F., Baker, Malchus B. Jr., Gotfried, Gerald J. April, 2000. heavy thinning of ponderosa pine stands: an Arizona case study. USDA Forest Service, Rocky Mountain Research Station. Research Paper RMRS-RP-22.

Gruel, G.E. 1983. Fire and Vegetatative trends in the Northern Rockies: Interpretations from 1871-1982 photographs. U.S. For. Serv. Gen. Tech. Rep. INT-158. 117pp.

Harris, L.D. 1984. The fragmented forest: island biogeography theory and preservation of biotic diversity. Unversity of Chicago Press. Chicago Illinois. 211 pp.

Hart, MM 1994. Past and Present Vegetative and wildlife diversity in relation to an existing reserve network: A GIS evaluation of the Seeley-Swan Landscapre, Northwestern Montana. M.S. Thesis, Univ. Montana, Missoula. 288pp. 
Heijl, S.J., and L.C. Paige. 1994. A preliminary assessment of birds in continuous and fragmented forests of western red cedar / western hemlock in northern Idaho. pp. 189-197 in D. M. Baumgartner and J. E. Lotan eds., Symposium proceedings on interior cedarhemlock-white pine forests: ecology and management. Wash. State Univ., Pullman.

Hunter, M.L. 1997. The biological landscape. Pages. 57-66, in K.A. Kohm and J.F. Franklin, eds. Creating a Forestry for the $21^{\text {st }}$ Century: The Science of Ecosystem Management. Island Press, Washington, D.C.

Hutto, R. L. 1995. Composition of bird communities following stand-replacement fires in northern Rocky Mountain (U.S.A.) conifer forests. Conservation Biology 9:1041-1058.

Kasworm, W. F. and T. L. Manley. 1990. Road and trail influences on grizzly bears and black bears in northwest Montana. International Conference on Bear Research and Management 8:79-84.

Losensky, J.B. 1987. A Strategy to implement ecosystem maintenance burning on the Lolo National Forest. USDA For. Serv. Intern. Rept. 89pp. _ . 1997. Historical vegetation of Montana. DNRC Intern. Rept. 100pp.

Kelly, G. M. 1977. Fisher (Martes pennanti) biology in the White Mountain National Forest and adjacent areas. Dissertation, University of Massachusetts, Amherst, Massachusetts.

McCallum, D. A. 1994. Flammulated owl (Otus flammeolus). Pages 1-24 in The Academy of Natural Sciences; The American Ornithologists' Union, Philadelphia, Pennsylvania.

McClelland, B. R., S. S. Frissell, W. C. Fischer, and C. H. Halvorson. 1979. Habitat management for hole-nesting birds in forests of western larch and Douglas-fir. Journal of Forestry 77:480-483.

Mersmann, T. J. 1989. Foraging ecology of bald eagles on the northern Chesapeake Bay with an examination of techniques used in the study of bald eagle food habits. M. S. Thesis, Virginia Polytechnic Institute and State University, Blacksburg, Virginia.

Montana Bald Eagle Working Group. 1994. Montana bald eagle management plan. Montana Bald Eagle Working Group (Montana bald eagle management plan. U. S. Department of Interior, Bureau of Land Management, Billings, Montana.

Montana Department of Environmental Quality.1996. Montana 303(d) List: Montana DEQ, Helena, MT.

Montana Department of Environmental Quality.2000. Draft Montana 303(d) List: A Compilation of Impaired and Threatened Waterbodies in Need of Water Quality Restoration. Montana DEQ, Helena, MT.

Montana Department of Fish, Wildlife and Parks. 1994. Immediate Actions (for bull trout restoration). Lang Peterman, Administrator, Fisheries Division). 
Montana Department of Natural Resources and Conservation 1999, Environmental Assessment, Clearwater River Timber Sale Projects. Clearwater State Forest, Greenough, MT. $128 \mathrm{pp}$.

Montana Department of Natural Resources and Conservation 1999, Final Environmental Impact Statement, Sour Fish Timber Sale. Clearwater State Forest, Greenough, MT. 105pp.

Montana Department of Natural Resources and Conservation 2003, Environmental Assessment, Dirty Ike Timber Sale. Missoula Unit Office, Missoula, MT.

Montana Department of Natural Resources and Conservation 2003, Environmental Assessment, Lost Bear Timber Sale. Clearwater State Forest, Greenough, MT.

Montana Department of Natural Resources and Conservation 2003, Montana administrative rules for forest management, streamside management zones and best management practices. Montana Forest Management Bureau, Missoula, Montana.

Paton, P.W. 1994. The effect of edge on avian nest success: How strong is the evidence? Conservation Biology. 8(1):17-26.

Pfister, R. D., B. L. Kovalchik, S. F. Arno, and R. C. Presby. 1977. Forest habitat types of Montana. U. S. Department of Agriculture, Forest Service, Intermountain Forest and Range Experiment Station, Ogden, Utah.

Powell, R.A., and W.J. Zielinsky. 1994. Fisher pp.38-73 in L.F. Ruggiero, K.B. Aubry S.W. Buskirk, L.J. Lyon, and W.J. Zielinski eds., The scientific basis for conserving forest carnivores (American marten, fisher, lynx, and wolverine) in the western United States. U.S. For. Serv. Gen. Tech. Rep. RM-254. 184 pp.

Powell, R. A. 1977. Hunting behavior, ecological energetics and predator-prey community stability of the fisher (Martes pennanti). Dissertation, University of Chicago, Chicago, Illinois.

. 1978. A comparison of fisher and weasel hunting behavior. Carnivore 1:28-34.

Ruediger, B., J. Claar, S. Gniadek, B. Holt, L. Lewis, S. Mighton, B. Naney, G. Patton, T. Rinaldi, J. Trick, A. Vandehey, F. Wahl, N. Warren, D. Wenger, and A. Williamson. 2000. Canada lynx conservation assessment and strategy. U. S. Department of Agriculture, Forest Service, Missoula, Montana. R1-00-53.

Stalmaster, M. V. 1987. The bald eagle. Universe Books, New York, New York.

Thompson, I. D. and R. W. Stewart. 1998. Management of moose habitat. Pages 377-401 in A. W. Franzmann and C. C. Schwartz, eds. Ecology and management of the North American moose. Smithsonian Institution Press, Washington, D. C.

United States Department of Agriculture, Natural Resources and Conservation Service and the Forest Service: Soil Survey of Missoula County Area, Montana

U.S.D.A. Forest Service. 1977. The visual management system. National Forest Landscape 
Management. Vol. 2, Chap. 1. USDA Forest Service, Agricul. Hndbk. No 462, 47 pp.

U.S.D.A. Forest Service. 1995. Landscape aesthetics: a handbook for scenery management. USDA Forest Service, Agricul. Hndbk. No. 701. 87pp.

Vander Haegen, W.W., and R.M. DeGraaf. 1996. Predation on artificial nests in forested riparian buffer strips. J. Wildl. Manage. 60:542-550.

Waller, J. S. and R. D. Mace. 1997. Grizzly bear habitat selection in the Swan Mountains, Montana. Journal of Wildlife Management 61:1032-1039. 
Headquarters Timber Sale - EA

\section{Appendix A: Maps and Figures}




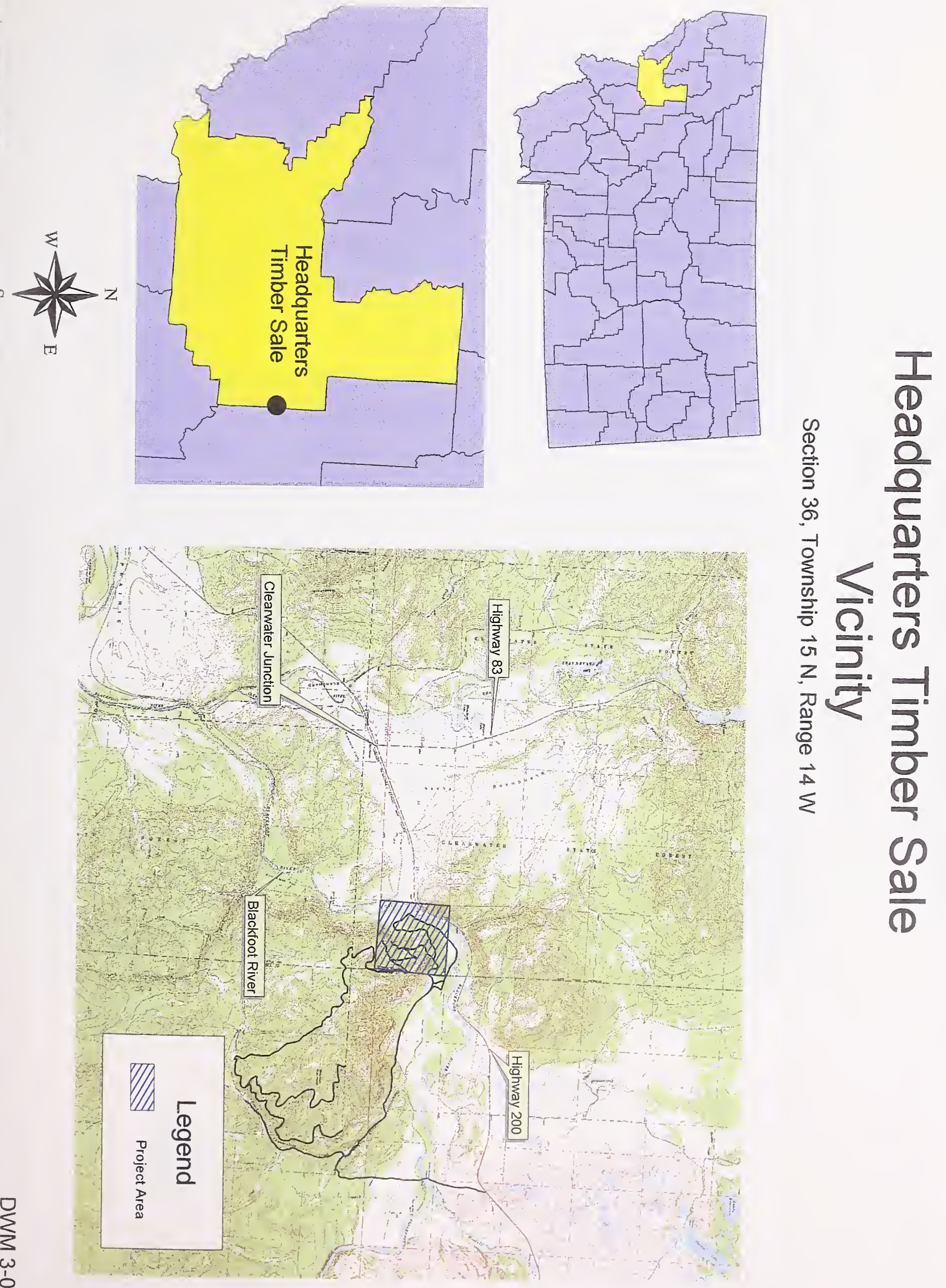

$\infty$ 


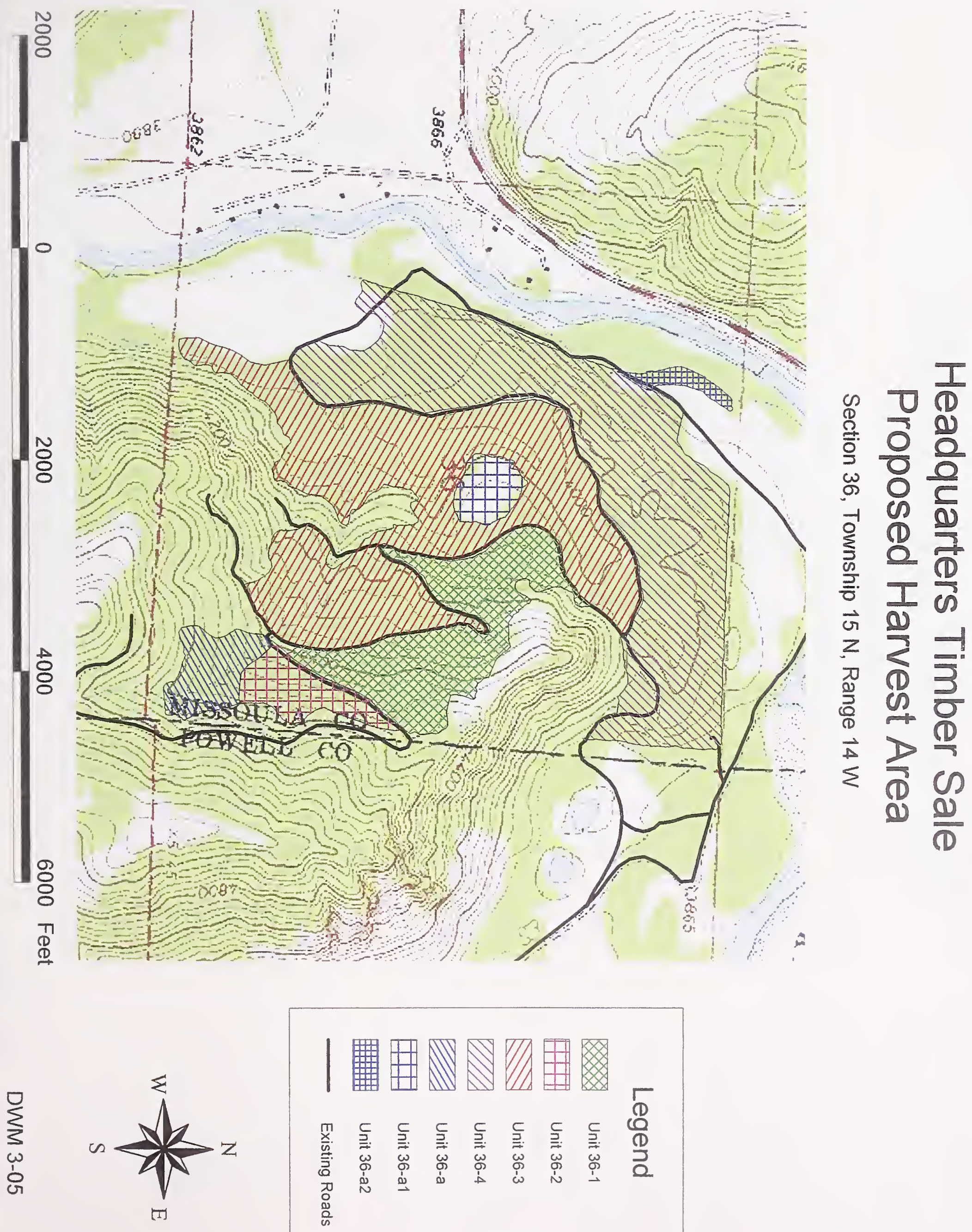



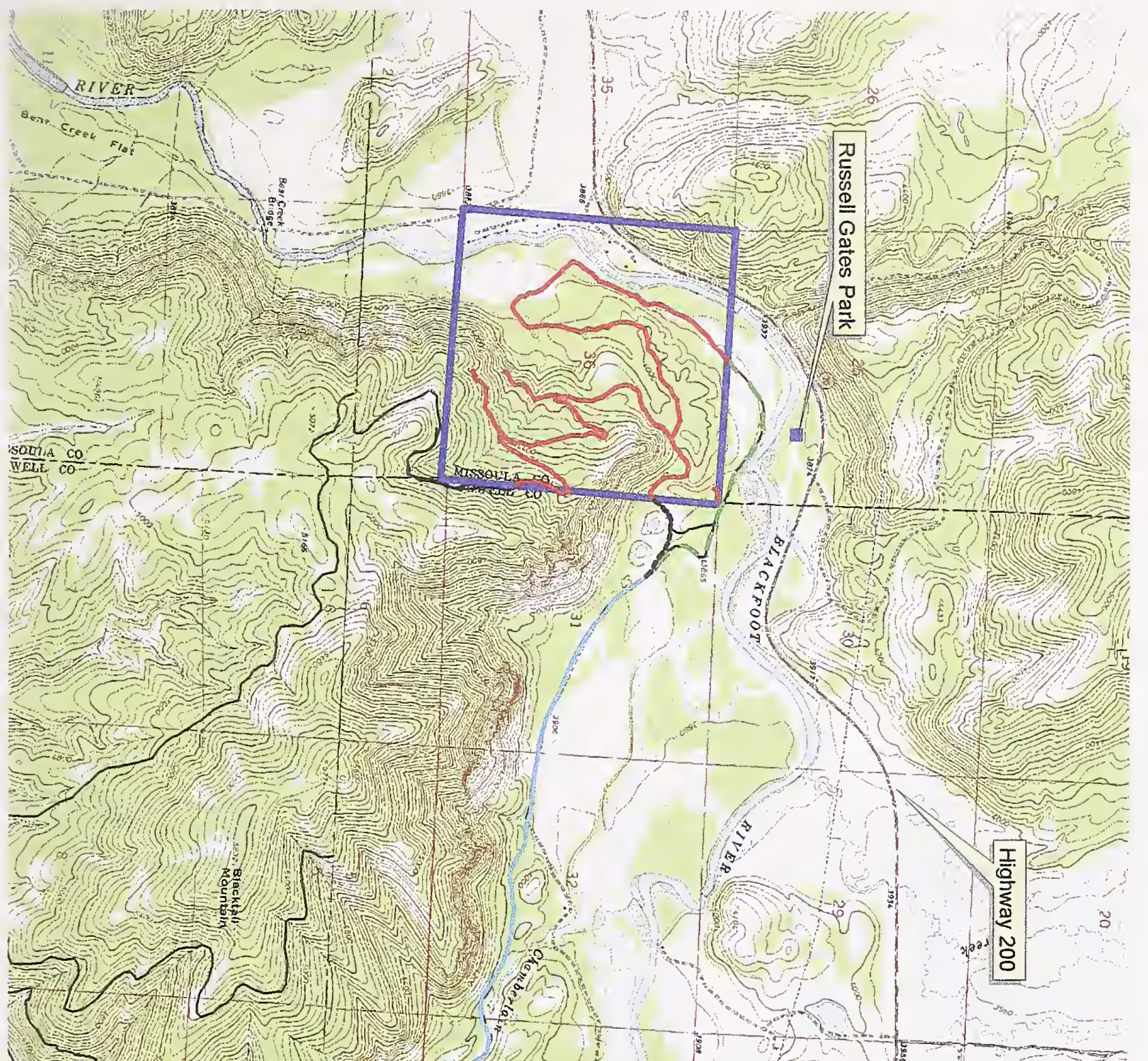

$\overrightarrow{\mathrm{t}}$
言
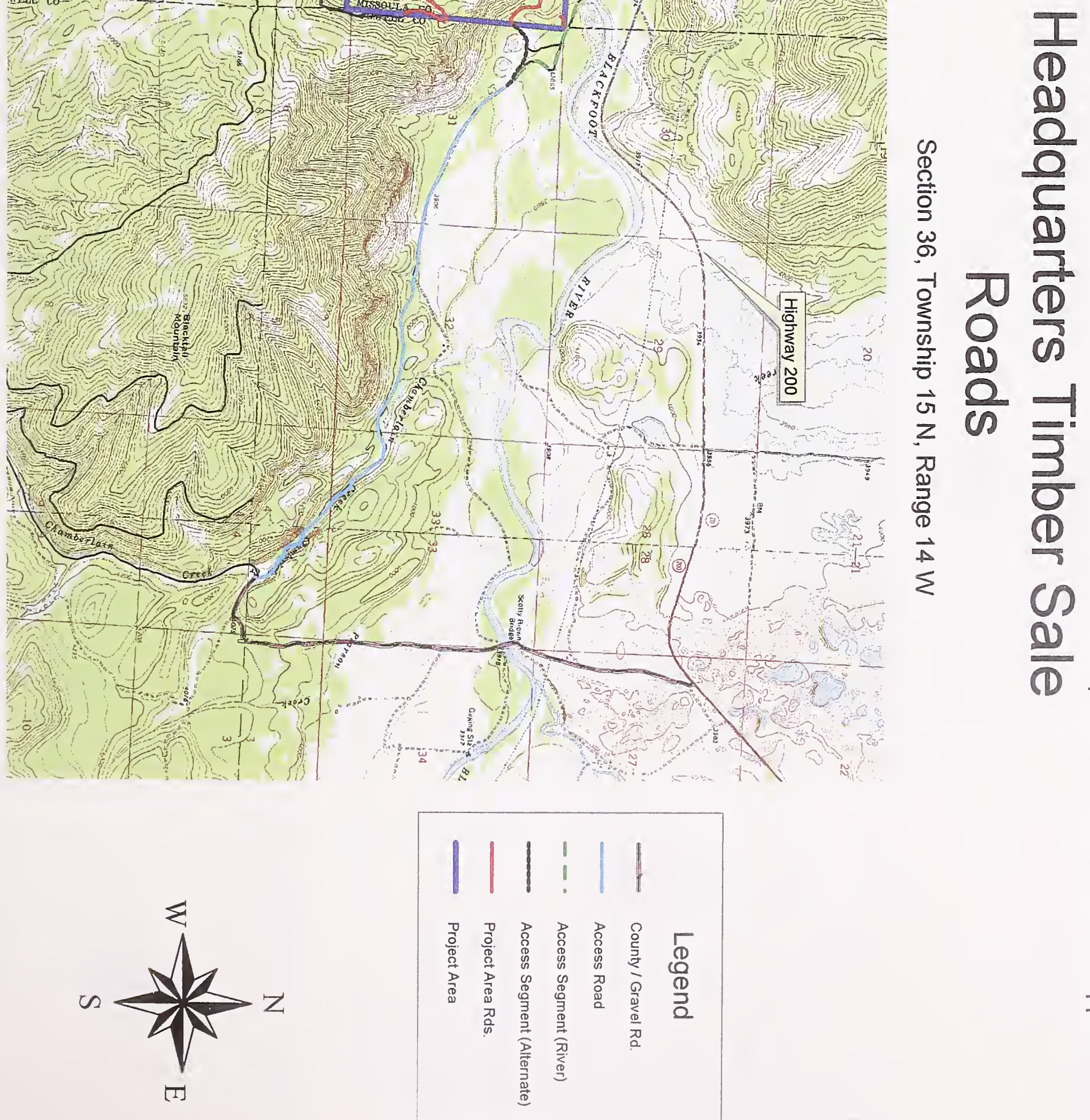


Headquarters Timber Sale EA - Appendix A-5

\section{Watershed Map}

Figure A-5

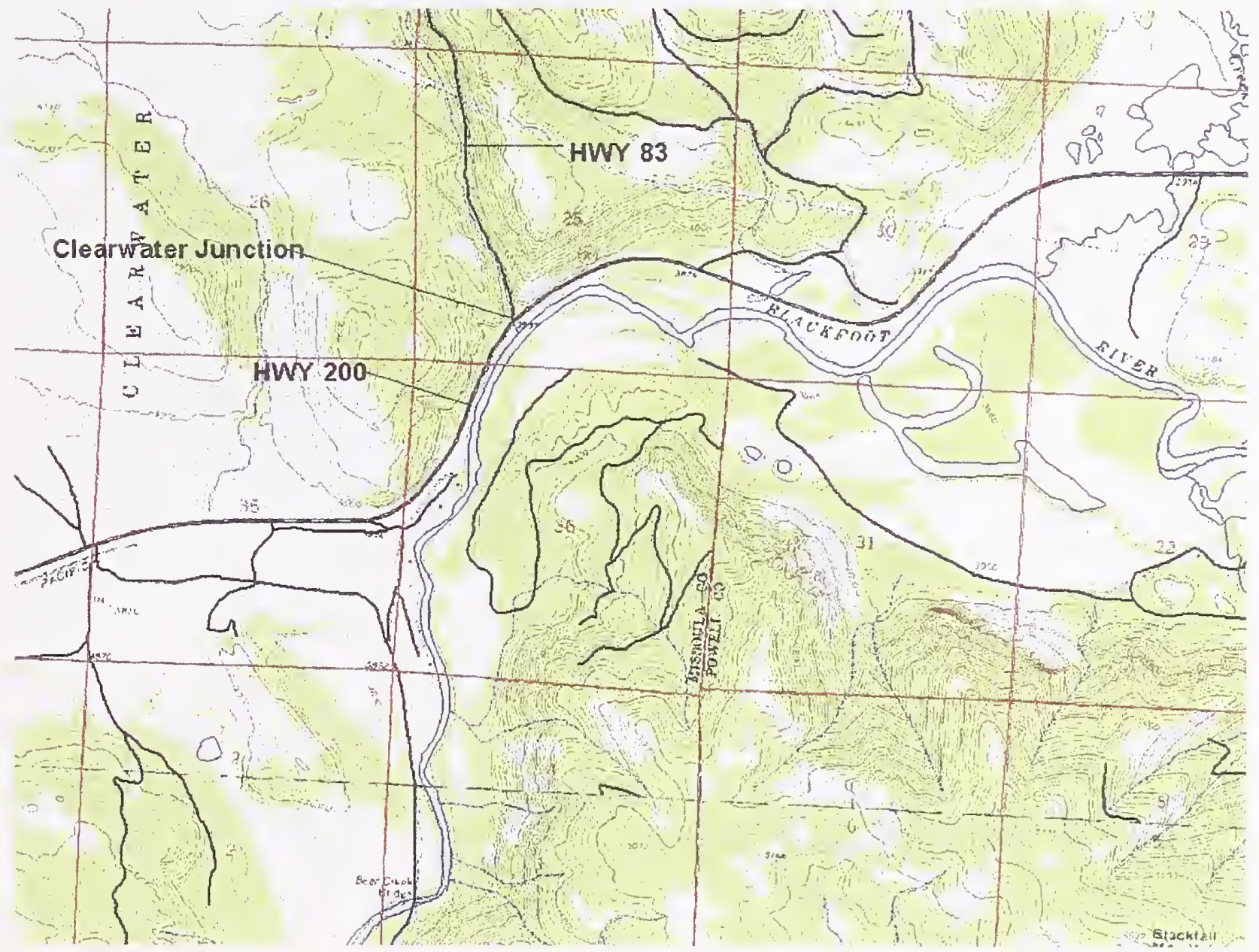



Headquarters Timber Sale EA - Appendix A-6

\section{Geology Map}

Figure A-6

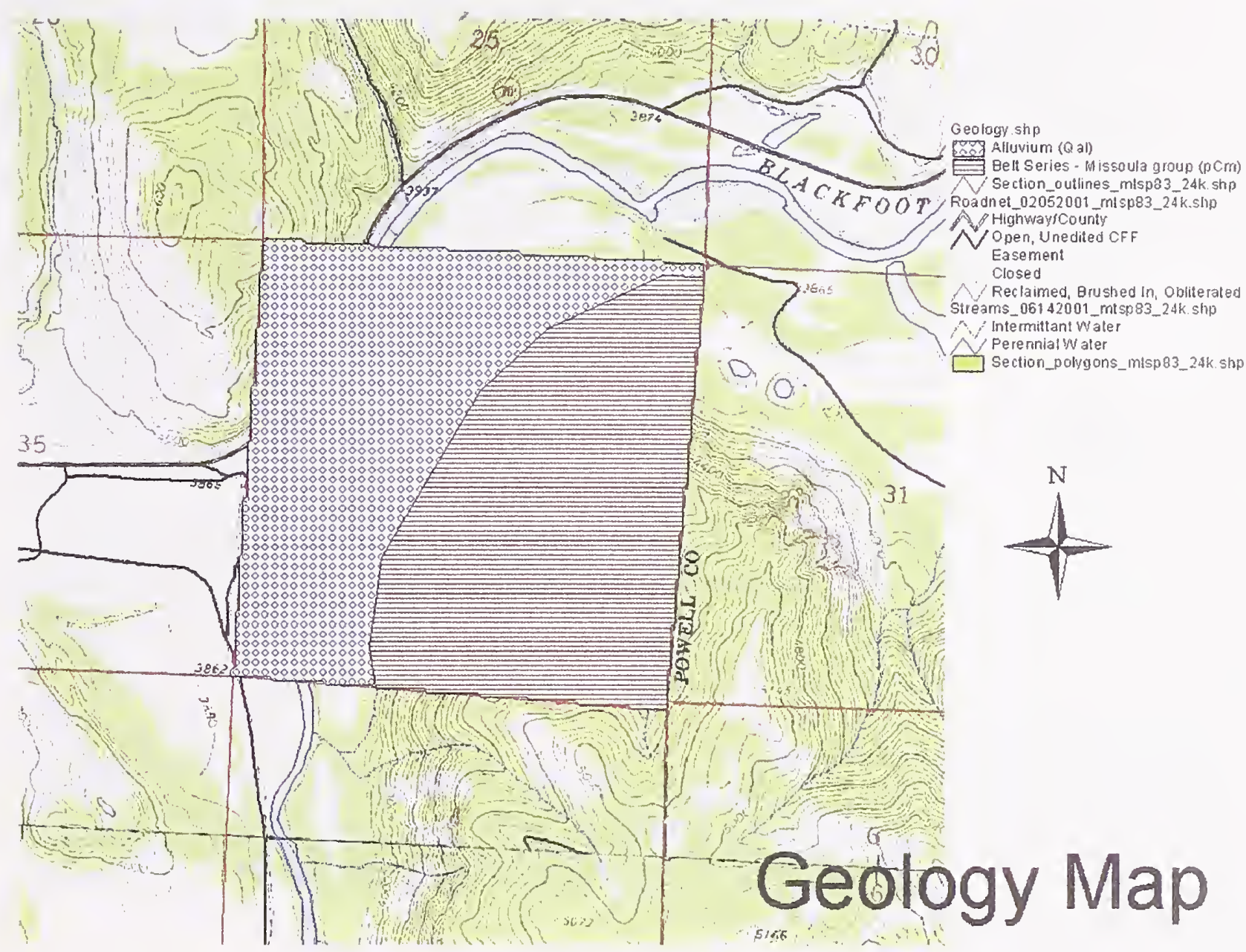



Headquarters Timber Sale EA - Appendix A-7

\section{Soils Map}

Figure A-7

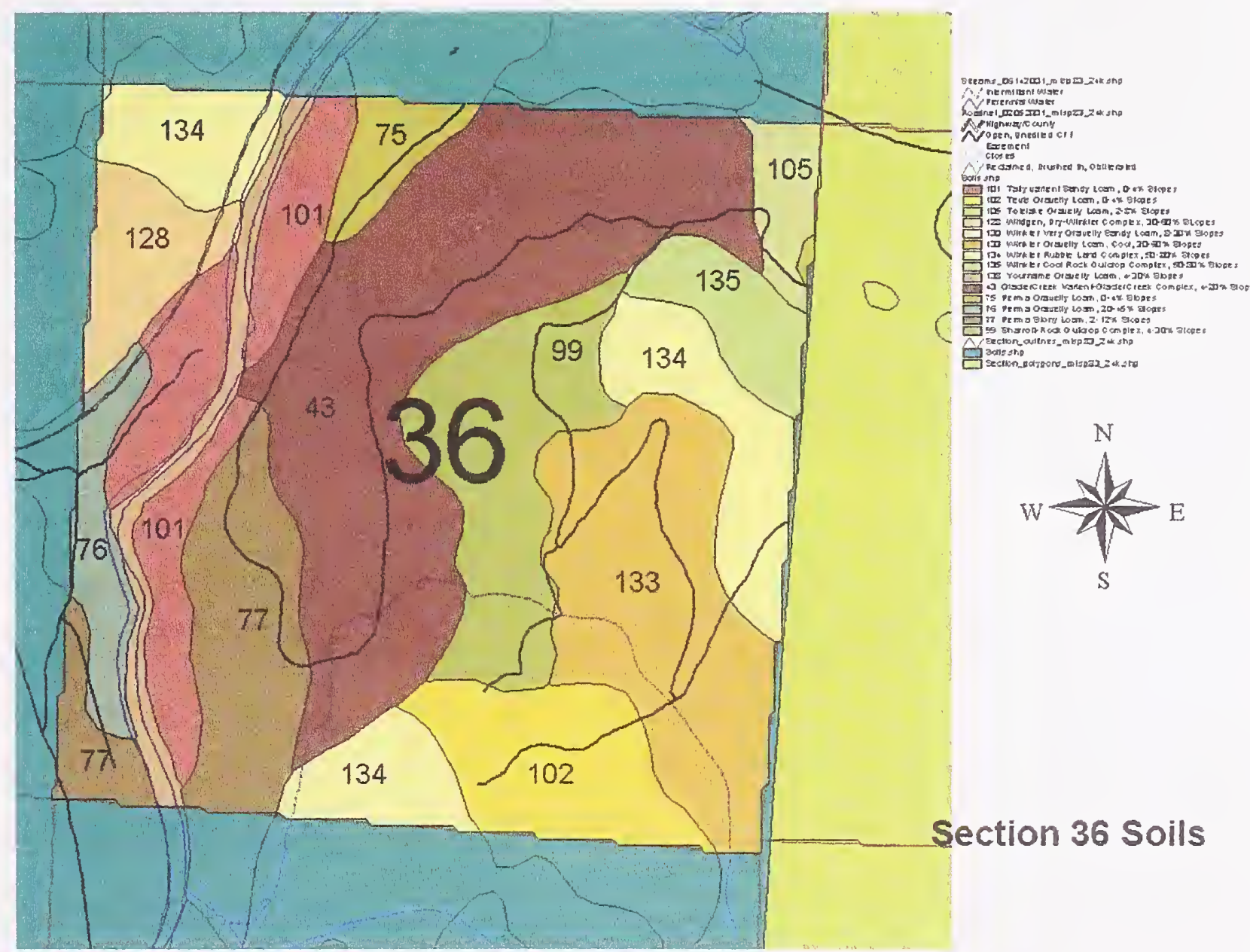



Headquarters Timber Sale - EA - Appendix A-8
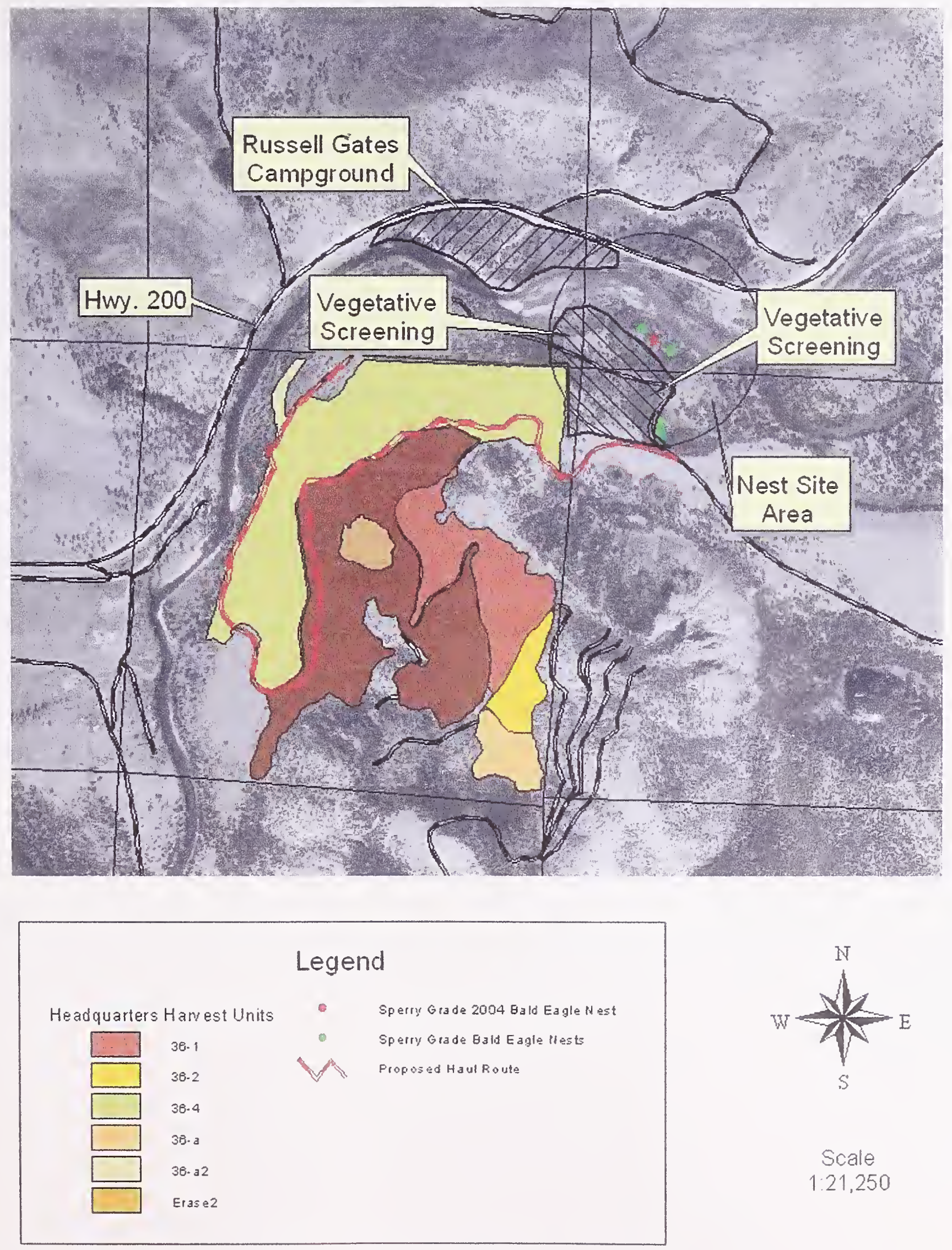

Scale

$1: 21,250$

Figure A-8. Relationship of Bald Eagle nests to proposed action activities and surrounding features. 

Headquarters Timber Sale - EA

\section{Appendix B: Initial and Revised Proposals and Public}

Notice 



\section{INITIAL PROPOSAL \\ HEADQUARTERS TIMBER SALE \\ JULY 26, 1999}

The Montana Department of Natural Resources and Conservation, Clearwater Unit, is proposing a timber sale within the following sections-W/2 section 2 , NENE, NWNE, section 10, T14N R14W, and section 36, T15N R14W.

The primary objective of the proposed action is to produce income for the School Trust Fund, it is hoped that between $\$ 400,000$ and $\$ 800,000$ (using an estimated stumpage rate of $\$ 200 / M B F$ ) in revenue would be generated by the proposed action. In keeping with the DNRC's State Forest Land Management Plan, the secondary objective of the proposed action would be to alleviate those existing stand conditions which are a result of the suppression of wildfire. Such conditions include, but are not limited to-overstocked conditions, an abnormally high percentage of Douglas-fir, in both the under and overstories, and the presence of insects and diseases which would have been either reduced or eliminated had fire been allowed to play it's role in stand development.

Selective harvesting, favoring Western larch and ponderosa pine as retention trees, would be the primary harvest method employed. The proposed action would not include any clearcutting.

The total volume estimated to be harvested is $2-4$ million board feet. It is expected that the construction of 1-3 miles of new road would be required, and up to 10 miles of existing roads would be reconditioned in order to meet BMP requirements. The proposed action would be implemented in 2001 with anticipated completion in 2004.

This area is known habitat for white-tailed deer, mule deer, elk, and Bald Eagles. The possibility also exists that sensitive animal and plant species use the area. The proposed action within section 36 may involve the selective removal of some trees within the Blackfoot River Recreation Corridor. In addition, the Blackfoot River, which flows through section 36, is known Bull Trout habitat.

In preparation for the timber sale, such specialists as wildlife biologists, hydrologists, soils scientists, and archaeologists, as well as neighboring landowners, and special interest groups would be consulted.

The Department of Natural Resources and Conservation invites comments and suggestions concerning this proposal from all interested parties. Please respond by August 26, 1999.

Please write to:

$$
\begin{aligned}
& \text { Jonathan Hansen } \\
& \text { Montana DNRC } \\
& \text { Cleanwater State Forest } \\
& \text { Box } 388 \\
& \text { Greenough, MT } 59836
\end{aligned}
$$

Phone: $244-5857,5870$ 



\section{REVISED PROPOSAL \\ HEADQUARTERS TIMBER SALE \\ February 12, 2001}

The Montana Department of Natural Resources and Conservation, Clearwater Unit, is proposing a timber sale within the following sections-W $1 / 2$ section $2, N^{1 / 2}$ NE $1 / 4$, section 10 , T14N R14W, and section $36, \mathrm{~T} 15 \mathrm{~N}$ R14W.

The primary objective of the proposed action is to produce income for the School Trust Fund. It is hoped that between $\$ 400,000$ and $\$ 800,000$ (using an estimated stumpage rate of $\$ 200 / \mathrm{MBF}$ ) in revenue will be generated by the proposed action. In keeping with the DNRC's State Forest Land Management Plan, the secondary objective of the proposed action would be to alleviate those existing stand conditions that are a result of the suppression of wildfire. Such conditions include, but are not limited to-overstocked conditions, an abnormally high percentage of Douglas-fir, in both the under and over stories, and the presence of insects and diseases which would have been either reduced or eliminated had fire been allowed to play it's role in stand development.

Selective harvesting, favoring Western larch and ponderosa pine as retention trees, would be the primary harvest method employed. The proposed action would not include any clearcutting.

The total volume estimated to be harvested is $2-4$ million board feet. It is expected that the construction of 1-3 miles of new road would be required, and up to 10 miles of existing roads would be reconditioned in order to meet BMP requirements. The proposed action would be implemented in 2003 with anticipated completion in 2008.

This area is known habitat for white-tailed deer, mule deer, elk, and Bald Eagles. The possibility also exists that sensitive animal and plant species use the area. In addition, the Blackfoot River, which flows through section 36, is known Bull Trout habitat.

In preparation for the timber sale, such specialists as wildlife biologists, hydrologists, soils scientists, and archaeologists, as well as neighboring landowners, and special interest groups would be consulted.

The Department of Natural Resources and Conservation invites comments and suggestions concerning this proposal from all interested parties. Please respond by March 16, 2001.

Please write to:

Rob Lionberger

Montana DNRC

Clearwater State Forest

Box 388

Greenough, MT 59836

Phone: 244-5857 E-mail: rlionberger@state.mt.us 



\section{REVISED PROPOSAL HEADQUARTERS TIMBER SALE May 15, 2002}

The Montana Department of Natural Resources and Conservation, Clearwater Unit, is proposing a timber sale within the following sections-W $1 / 2$ section $2, N^{1 / 2}$ NE $1 / 4$, section $10, T 14 N$ R 14 W, and section 36, T15N R14W.

The primary objective of the proposed action is to produce income for the School Trust Fund. It is hoped that between $\$ 400,000$ and $\$ 800,000$ (using an estimated stumpage rate of $\$ 200 / \mathrm{MBF}$ ) in revenue will be generated by the proposed action. In keeping with the DNRC's State Forest Land Management Plan, the secondary objective of the proposed action would be to alleviate those existing stand conditions that are a result of the suppression of wildfire. Such conditions include, but are not limited to-overstocked conditions, an abnormally high percentage of Douglas-fir, in both the under and over stories, and the presence of insects and diseases which would have been either reduced or eliminated had fire been allowed to play it's role in stand development.

Selective harvesting, favoring Western larch and ponderosa pine as retention trees, would be the primary harvest method employed. The proposed action would not include any clearcutting.

The total volume estimated to be harvested is $2-4$ million board feet. It is expected that the construction of 1-3 miles of new road would be required, and up to 10 miles of existing roads would be reconditioned in order to meet BMP requirements. The proposed action would be implemented in 2003 with anticipated completion in 2008.

This area is known habitat for white-tailed deer, mule deer, elk, and Bald Eagles. The possibility also exists that sensitive animal and plant species use the area. In addition, the Blackfoot River, which flows through section 36, is known Bull Trout habitat.

In preparation for the timber sale, such specialists as wildlife biologists, hydrologists, soils scientists, and archaeologists, as well as neighboring landowners, and special interest groups would be consulted.

The Department of Natural Resources and Conservation invites comments and suggestions concerning this proposal from all interested parties. Please respond by June 17, 2002.

Please write to:
Dave Marsh
Montana DNRC
Clearwater State Forest
48455 Sperry Grade Rd.
Greenough, MT 59823-9635

Phone: 244-5857_E-mail: dmarsh@state.mt.us 



\section{-Public Notice- \\ Department of Natural Resources and Conservation Timber Sale}

The Montana Department of Natural Resources and Conservation, Clearwater Unit, is in the preliminary stages of preparing the Headquarters Timber Sale located in portions of the $\mathrm{W} 1 / 2$ of section $2, \mathrm{~N}^{1 / 2} \mathrm{NE} 1 / 4$ of section 10 , T14N R14W, and section $36, \mathrm{~T} 15 \mathrm{~N}$ R14W. The Department would like public input regarding the proposal to harvest between an estimated 2-4 million board feet of timber, construct approximately 1-3 miles of new road and recondition up to 10 miles of existing road to access these areas. Those interested should address written comments to:

Dave Marsh

Montana DNRC

Clearwater State Forest

48455 Sperry Grade Rd.

Greenough, MT 59823-9635

Phone: (406) 244-5857

Comments must be received by 5:00 PM on May 17, 2002. 




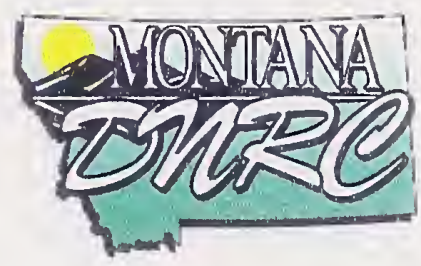

\title{
MONTANA DEPARTMENT OF NATURAL RESOURCES AND CONSERVATION
}

\author{
CLEARWATER UNIT \\ BOX 48455 SPERRY GRADE ROAD \\ GREENOUGH, MT. \\ 59823-9635
}

(406) $244-5857$

Persons with disabilities who need an alternative, accessible format of this document should contact the DNRC at the above address or phone number.

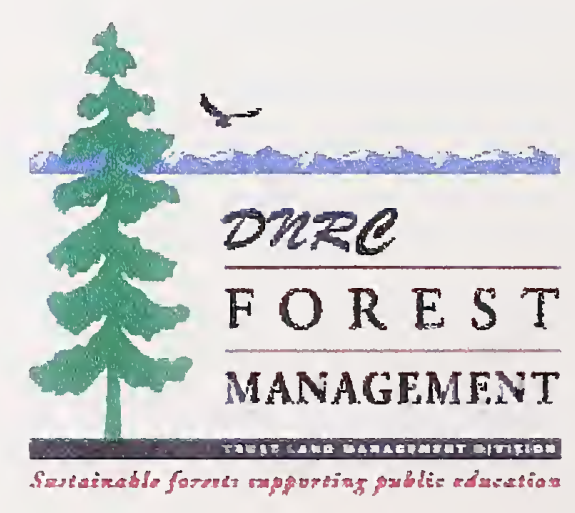

